UNIVERSIDADE DE SÃO PAULO

FACULDADE DE FILOSOFIA, LETRAS E CIÊNCIAS HUMANAS DEPARTAMENTO DE LETRAS MODERNAS PROGRAMA DE PÓS-GRADUAÇÃO EM LÍNGUA INGLESA E LITERATURAS INGLESA E NORTE-AMERICANA

ELISABETE VIEIRA CAMARA

\title{
A forma do ensaio e a construção do tempo ficcional em Lucia Miguel Pereira e Virginia Woolf
}




\section{ELISABETE VIEIRA CAMARA}

A forma do ensaio e a construção do tempo ficcional em Lucia Miguel Pereira e Virginia Woolf

Tese apresentada ao Programa de PósGraduação em Língua Inglesa e Literaturas Inglesa e Norte-Americana, do Departamento de Letras Modernas da Faculdade de Filosofia, Letras e Ciências Humanas, da Universidade de São Paulo, para obtenção do título de Doutor em Letras.

Orientadora: Profa. Dra. Sandra G.T. Vasconcelos

São Paulo 
CAMARA, Elisabete Vieira

A forma do ensaio e a construção do tempo ficcional em Lucia Miguel Pereira e Virginia Woolf

Tese apresentada ao Programa de PósGraduação em Língua Inglesa e Literaturas Inglesa e Norte-Americana, do Departamento de Letras Modernas da Faculdade de Filosofia, Letras e Ciências Humanas, da Universidade de São Paulo, para obtenção do título de Doutor em Letras.

Aprovado em:

Banca Examinadora

Profa. Dra. Sandra G. T. Vasconcelos Instituição: DLM/USP

Julgamento:

Assinatura:

Profa. Dra. Nádia B. Gotlib

Instituição: DLCV/USP

Julgamento:

Assinatura:

Prof. Dr Luís Bueno

Instituição: UFPr

Julgamento:

Assinatura:

Prof. Dr. Ricardo Iannace

Instituição: Faculdade de Tecnologia Estadual

Julgamento:

Assinatura:

Prof. Dr. André Bueno

Instituição: UFRJ

Julgamento:

Assinatura: 
Para meu pai 


\section{AGRADECIMENTOS}

Agradeço a minha orientadora Profa. Dra. Sandra Guardini T. Vasconcelos pela orientação precisa e minuciosa.

À Profa. Dra. Nádia B. Gotlib e ao Prof. Dr. Ricardo Iannace por nortearem a finalização da tese.

Aos meus pais, pelo apoio ao longo dessa trajetória.

Ao carinho dos meus amigos, especialmente ao Kiko pelo estímulo durante a elaboração deste trabalho.

Ao amigo Walter de Sales Júnior (in memorian). 


\section{RESUMO}

CAMARA, Elisabete Vieira. A forma do ensaio e a construção do tempo ficcional em Lucia Miguel Pereira e Virginia Woolf. 2011, 198 f. Tese (Doutorado) - Faculdade de Filosofia, Letras e Ciências Humanas, da Universidade de São Paulo, São Paulo, 2011.

O presente trabalho tem por finalidade discutir a leitura que Lucia Miguel Pereira faz de Virginia Woolf em quatro ensaios, "Dualidade de Virginia Woolf", "Crítica e feminismo", "O Big Ben e o carrilhão fantasista" e "Assombração", nos quais explora aspectos importantes dos ensaios e romances da escritora inglesa. Para Lucia Miguel Pereira, a nova forma do ensaio idealizada por Woolf consiste em uma renovação estética que a distingue de seus predecessores e contemporâneos pela união da linguagem crítica com a narrativa. Denominada de abordagem humanista pela crítica brasileira, a concepção de Woolf possibilita um espaço de criação artística capaz de envolver o leitor e estabelecer uma relação de intensa proximidade com ele. Entretanto, as explicações de natureza estética de Woolf, que congregam mito e movimento feminista para a criação dessa nova forma, são vistas por Pereira mais como resultado de uma visão pessoal da escritora do que como crítica literária propriamente dita. Com relação ao tempo ficcional, seguindo a sugestão de Lucia Miguel Pereira a respeito da necessidade de interação entre tempo cronológico e psicológico no romance, é feita uma leitura comparativa de To the lighthouse e Mrs. Dalloway, de Virginia Woolf, e Amanhecer, da autoria da escritora brasileira, a fim de demonstrar como ambas lidaram com a temporalidade no romance. O fio condutor da análise é a proposta estética de Woolf e o ponto de vista da crítica brasileira.

Palavras-chave: Lucia Miguel Pereira; Virginia Woolf; ensaio; romance; tempo. 


\begin{abstract}
This thesis aims at investigating Lucia Miguel Pereira's reading of Virginia Woolf in four of her articles, "Dualidade de Virginia Woolf", "Crítica e feminismo", "O Big Ben e o carrilhão fantasista", and "Assombração", in which she explores key aspects of the English writer's essays and novels. According to Lucia Miguel Pereira, Woolf's essays are formally innovative and her renewal of the form distinguishes her from her predecessors and contemporaries. Such differences are reinforced by the simultaneous use of narrative and critical language, which raises the essay to status of an artistic creation, capable of involving the reader by means of an interaction and closeness which Pereira names as a humanistic approach. However, Pereira considers Woolf's explanations of her aesthetics, which include myth and feminism, as resulting much more from her very personal stance than as literary criticism as such. As for fictional time, taking up Lucia Miguel Pereira's suggestion about the necessary interaction between chronological and psychological time in the novel, we compare To the lighthouse and Mrs. Dalloway, by Virginia Woolf, and Amanhecer, by the Brazilian novelist, in order to demonstrate how both writers deal with temporality in the novel, bearing in mind Woolf's aesthetic proposal and the Brazilian critic's point of view.
\end{abstract}

Keywords: Lucia Miguel Pereira; Virginia Woolf; essay; novel; time. 



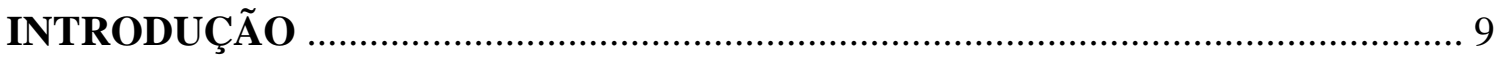

CAPÍTULO II - O CONCEITO DE TEMPORALIDADE FICCIONAL EM LUCIA MIGUEL PEREIRA

CAPÍTULO III - A CONSTRUÇÃO DO TEMPO EM MRS DALLOWAY, TO THE LIGHTHOUSE E AMANHECER

CAPÍTUlo IV - O ENSAIO COMO ESPAÇO DE CRIAÇÃo ARTístiCa

CONCLUSÃO. 


\section{INTRODUÇÃO}

Lucia Miguel Pereira (1901-1959) é uma referência no cenário literário brasileiro pelo seu trabalho como crítica literária, biógrafa, historiadora da literatura e ficcionista, apesar de sua produção romanesca não ter tido muita repercussão. Seus textos críticos foram veiculados em periódicos tais como A Revista do Brasil, O Estado de São Paulo e O Correio da Manhã. Nesse último jornal, dedicou quatro ensaios à também ensaísta e escritora inglesa Virginia Woolf (18821941), nos quais aborda questões relacionadas à forma do ensaio, às ligações de sua crítica com o feminismo e à construção do tempo ficcional no romance como um meio fundamental para a recriação da realidade na narrativa.

É a partir desses pontos de vista que delineamos nossa análise. Primeiramente, valemonos do estudo das manifestações sociais e literárias da década de 30, de modo a situar o contexto em que viveu a crítica brasileira. Da mesma forma, evidenciamos as particularidades da sociedade inglesa no tempo de Virginia Woolf a fim de verificarmos como os aspectos sociais, políticos e científicos exerceram influências tanto na sua crítica quanto na sua produção literária.

Como ensaísta, Lucia Miguel Pereira dedicou textos não apenas aos escritores brasileiros do porte de Graciliano Ramos, José Lins do Rego e Rachel de Queiroz, entre outros, mas também à literatura universal: Dostoievski, Jane Austen e Cervantes, por exemplo. No entanto, é com a publicação de Machado de Assis- estudo crítico e biográfico, que acontece o reconhecimento de sua ensaística.

Em sua crítica literária, Pereira se sobressaiu pela lucidez analítica e seriedade com que conduz suas leituras. Daí, o alto grau de importância que atribui às ideias e à reflexão ao afirmar que "o pensamento é que vale, da sua sinceridade dependerá quase totalmente o valor da obra."”

\footnotetext{
${ }^{1}$ PEREIRA, Lucia Miguel. A leitora e seus personagens. Rio de Janeiro: Grafia, 2005. p. 90.
} 
Ao mesmo tempo em que confere um alto valor à capacidade de reflexão que o trabalho crítico deve motivar, também reconhece a importância da presença da "emoção estética"2 que Virginia Woolf trouxe para o ensaio. Isto é, o texto é tratado como um espaço para além da realização do pensamento crítico, que envolve o leitor e estabelece com ele uma interação; transforma-se em um objeto artístico capaz de atrair a atenção do outro e nele despertar o prazer em ler os livros ali analisados. Desse modo, colocou-se a favor de uma avaliação ponderada a partir da reflexão e do gosto da elaboração crítica.

No entanto, discorda das bases teóricas que Woolf ofereceu para explicar a nova forma do ensaio. Para ela, o conceito de androginia imbricado ao movimento feminista pode ser sentido apenas como uma confusão intelectual da crítica inglesa, assim como um problema de ordem pessoal relacionado aos seus recalques como mulher. Dessa maneira, o conceito que sustenta a estruturação da teoria que subjaz à nova forma do ensaio encontra-se muito mais relacionado aos conflitos existenciais da autora do que propriamente ao feminismo ou à crítica literária.

Pereira acredita ser determinante na composição do ensaio a relevância dos fatores externos que circundam a fatura do texto crítico, uma vez que considera o trabalho intelectual em interação com o meio que o circunda. Por isso, a razão não pode "ficar alheia às preocupações sociais" 3 .

No tocante à produção ficcional, Pereira, diferentemente dos escritores do regionalismo que enfocaram a literatura proletária e social, e, juntamente com outros escritores como Lúcio Cardoso e Clarice Lispector, voltou-se para uma abordagem psicológica ao priorizar os conflitos internos das personagens. Esse posicionamento não a impediu de compartilhar com seus contemporâneos as inquietações e dúvidas de uma época caracterizada pela incerteza. Suas personagens refletem a degeneração de padrões sociais, ao enfocar, particularmente, o universo feminino, temática de sua obra ficcional.

\footnotetext{
${ }^{2}$ Ibid., p. 89.

${ }^{3}$ Ibid., p. 89.
} 
Virginia Woolf, sensível às mudanças de sua época, elaborou uma extensa obra literária influenciada pelas transformações que ocorreram em várias áreas do conhecimento científico e tecnológico, das questões sociais e políticas que permearam o início do século $\mathrm{XX}$. Sua diversificada produção literária inclui ensaios, diários, biografias, cartas e romances que se notabilizam pela sensibilidade estética.

Os ensaios de Woolf se distinguiram de seus predecessores por unir a linguagem analítica à ficcional, imprimindo, dessa maneira, uma nova forma ao ensaio moderno, elevando-o, consequentemente, à posição de obra de arte. O ensaio, para ela, não tem uma forma préestabelecida; sua principal característica é a liberdade de expressão.

Quanto à estética romanesca, esta é delineada por uma nova perspectiva temporal advinda da ênfase no tempo psicológico, o qual passa por um processo de reelaboração a partir do sujeito. A teoria freudiana, por sua vez, colaborou no sentido de reforçar a importância dos processos psíquicos no fazer literário.

Em sua busca de uma ficção que se aproximasse da vida, Woolf percebeu que o que havia sido feito até então não correspondia aos seus anseios como romancista, porque "life escapes; and perhaps without life nothing else is worth while."4 Seus romances centram-se na apresentação de uma abordagem psicológica cujas reflexões das personagens tornam relativos o presente e o passado; as sensações são priorizadas em detrimento de um enredo mais voltado à realidade externa marcada pelo tempo cronológico.

É a esse aspecto do romance virginiano que Pereira se contrapõe, pois, de acordo com seu ponto de vista, a narrativa deve ter um maior comprometimento com a realidade externa, com o meio circundante, caso contrário, a trama estaria altamente comprometida. Na verdade, a crítica brasileira acredita que o enfoque dado por Woolf com relação à construção do tempo seria mais adequado ao conto do que ao romance.

\footnotetext{
4 “a vida se esvai; e talvez sem a vida nada mais valha a pena.”. WOOLF, Virginia. Virginia Woolf-Selected essays . David Bradshaw (Ed.). New York: Oxford University Press, 2008. p. 8. Tradução nossa.
} 
A fim de exemplificarmos os pontos de divergência entre ambas, comentamos três romances, Mrs Dalloway e To the lighthouse, de Virginia Woolf, e Amanhecer de Lucia Miguel Pereira, de forma a confrontar a construção da temporalidade na narrativa.

Verificamos que nos textos de Woolf existe a preponderância de uma estética voltada para o sujeito no sentido de elaborar um romance cujas preocupações são de cunho existencial, e, no qual o desenvolvimento da narração é traçado pelos pensamentos das personagens gerenciados por um tempo excessivamente psicológico. Essas características são mais evidenciadas em Mrs. Dalloway.

Já em To the lighthouse, a divisão nítida entre o presente e o passado permite à obra adquirir um enredo mais sequencial, apesar de ali também existir, em grande proporção, a circularidade temporal provocada pelos pensamentos e rememorações das personagens. No entanto, há um maior equilíbrio na coexistência dos tempos cronológico e psicológico que dá à obra certa linearidade. Dessa forma, é possível verificar aí os aspectos pertinentes ao romance, segundo a crítica brasileira.

No romance de Lucia Miguel Pereira, Amanhecer, o tempo é retrospectivo, centrado nas memórias de uma protagonista que também é narradora. Ela descreve parte de sua vida e reflete sobre os fatos que a levaram a questionar sua situação no presente. A obra evidencia os conceitos defendidos por Pereira com relação à construção do tempo ficcional, isto é, um tempo capaz de recriar a realidade externa com um mínimo de deformação, conferindo a ela um caráter mais verossímil. Por outro lado, isto não significa que a obra não apresente um veio psicologizante; ele existe, e se faz presente na narração das sensações vivenciadas pela protagonista, porém, ao contrário de Woolf, as experiências psicológicas não se encontram tão exacerbadas a ponto de romper com a realidade externa da vida cotidiana, prática e imediata. 
CAPÍtUlo I - LUCIA Miguel PEREIRA NAS LETRAS BRASILEIRAS 


\section{Atuação como intelectual}

Lucia Miguel Pereira foi uma personagem marcante do cenário intelectual brasileiro na primeira metade do século XX e há muitas razões para admirar seu desempenho nas letras nacionais, pois atuou como romancista, biógrafa, escritora de livros infantis, pesquisadora literária e tradutora. A mais importante refere-se ao fato de ter sido uma intelectual repleta de ousadia e garra em um meio que não se mostrava tão receptivo ao seu perfil autodidata e nem tão habituado à presença feminina atuante nessa seara. Sérgio Micelli em Intelectuais e Classe Dirigente no Brasil (1920-1945) afirma:

Os "herdeiros" da fração intelectual (...) entram em contacto com as profissões intelectuais através das instituições que se incubem, em bases profissionais, da formação das novas gerações de assessores e homens políticos (os estabelecimentos de ensino superior nos ramos liberais, as organizações político-partidárias, etc. $)^{1}$.

Pereira inseriu-se nessa atmosfera, fazendo uso da palavra escrita para edificar seu legado crítico. Publicados pelos jornais e revistas da época, os ensaios da brasileira veiculam mensagens de grande rigor analítico que, surpreendentemente, são construídos por meio de uma linguagem de tom leve cuja escrita interativa dá a impressão de um diálogo, uma conversa informal com o leitor.

A crítica brasileira voltou-se aos aspectos humanísticos de maneira contundente ao observar a criatura humana e a complexidade da vida. Politicamente, não tinha uma posição ideológica definida, uma vez que era teísta, espiritualista e conservadora. No entanto, era simpática a certos aspectos da Rússia soviética. Na realidade, considerava esse posicionamento ideológico um dilema e propunha uma reflexão acerca das questões humanas em pleno regime ditatorial do Estado Novo, ou

\footnotetext{
${ }^{1}$ MICELI, Sérgio. Intelectuais e classe dirigente no Brasil (1920- 1945). Rio de Janeiro: DIFEL, 1979. p. XXII.
} 
seja, uma época em que a liberdade individual fora cerceada e os meios de comunicação controlados pelo governo.

Suas primeiras produções na área da crítica foram escritas para a Revista Elo (1927-1929), uma publicação do Colégio Notre Dame de Sion no Rio de Janeiro, onde Lucia Miguel Pereira estudou. Juntamente com Lúcia Magalhães e Lia Correia Dutra, foi responsável pela revista, na qual já começava a escrever artigos transmitindo suas impressões de leituras. A revista foi organizada sob a liderança de Alceu Amoroso Lima no Centro Dom Vital, um local de publicações de cunho eminentemente católico, criado por Jackson de Figueiredo em 1922, com o objetivo de atrair a intelectualidade católica brasileira, uma vez que a hegemonia da Igreja Católica mostrava-se muito presente.

Mesmo com uma produção incipiente nessa fase inicial, a crítica brasileira já demonstrava as convicções que marcariam sua produção posterior. Antonio Candido, em seu artigo sobre Lucia Miguel Pereira, afirma que "embora essa produção de principiante não tenha grande relevo, é interessante como ponto de partida e já mostra alguns traços da sua personalidade intelectual"². Era o começo de uma crítica literária que se diversificaria posteriormente em outras atividades relacionadas à produção romanesca, traduções, biografias, entre outras.

Como escritora de romances, seu percurso literário se intensificou em 1933 com os livros Maria Luiza e Em surdina, de pouca ou quase nenhuma repercussão até porque não se enquadravam na corrente regionalista reinante na ficção brasileira dos anos 30. O enfoque de suas obras era de caráter intimista, o qual retratava a reflexão das personagens femininas acerca da condição da mulher como ser humano, político e social. Como exemplo dessa abordagem, no romance Em surdina, a heroína Cecília se

\footnotetext{
${ }^{2}$ CANDIDO, Antonio. O albatroz e o chinês. Rio de Janeiro: Ouro sobre azul, 2004. p. 129.
} 
move em espaços sociais definidos para a mulher sob a égide de um paternalismo protetor em uma angustiante espera matrimonial e uma dualidade da moral sexual (liberdade para os homens e castidade para as mulheres), fornecendo matéria-prima para uma narrativa reflexiva sobre o papel feminino inserido em um meio bastante conservador. Há nesse livro uma passagem que nos permite ver a atenção da romancista em relação à discriminação da mulher na sociedade. Ao pedir Cecília em casamento, Paulo diz:

- (...) O emprego que tenho para você, o melhor , o que me encheria de felicidade se você o quisesse, é o de minha mulher. Para que andar por aí, exposta a encontrar gente de toda a sorte, num lugar subalterno, se pode ser a rainha em sua casa... em nossa casa? Ser a razão e a recompensa da minha vida, não será uma ocupação melhor do que ser datilógrafa? $?^{3}$

As preocupações com a condição do feminino, por meio de reflexões, difundem a mulher como um ser pensante e atuante na sociedade, em oposição ao papel submisso e nulo que havia desempenhado até então. Pode-se dizer, portanto, que este foi o diferencial que Lucia Miguel Pereira apresentou como romancista e que a fez despontar no contexto literário da época.

Com relação aos romances da crítica brasileira, Nádia Batella Gotlib ressalta no ensaio "A literatura feita por mulheres no Brasil" que "a escritora problematiza a questão dos papéis sociais da mulher, detectando preconceitos e censuras, que causam frustrações e retrocessos no percurso das opções por comportamentos e atitudes a serem assumidas pela mulher numa sociedade fechada e altamente codificada" ${ }^{\text {. }}$

Mais tarde publicaria outros dois romances, Amanhecer (1934) e Cabra-Cega (1954). Além de quatro livros infantis: Fada menina, em 1939, que recebeu o prêmio

\footnotetext{
${ }^{3}$ PEREIRA, Lucia Miguel. Ficção reunida. Curitiba: Editora UFPR, 2006. p. 193.

${ }^{4}$ GOTLIB, Nádia. Working paper series. University of Oxford, Centre for Brazilian Studies, 1998. p. 6.
} 
anual do Instituto Nacional do Livro, e , em 1943, A floresta mágica, Maria e seus bonecos e A filha do Rio Verde.

Também traduziu as obras America, de Hendrik van Loom (1935), A vida trágica de Van Gogh, de Irving Stone (1940), Maria Madalena, de Bruckberger (1955), O tempo redescoberto, de Proust (1956) e Meditações, de Marco Aurélio (1957), assim como textos de outros autores consagrados como Kafka, Stephen Crane e Dostoievski. Já como pesquisadora, conseguiu resgatar, depois de uma árdua procura, o romance D.Guidinha do Poço, de Manuel de Oliveira Paiva, cujos originais foram parcialmente publicados no século XIX por José Veríssimo.

\section{Atuação como crítica literária}

A maior parte de seus textos foram publicados em jornais, e, desse modo, destinados ao público em geral, mantendo sempre seu estilo objetivo e claro, em um franco diálogo com a obra artística, utilizando-se de um irrefutável rigor analítico. Seus objetos variam entre romances, poesia, o humor, a própria crítica, história literária e questões de cunho sociológico, sempre atenta à realidade de seu tempo, o que a levou, em uma época marcada pela censura do governo getulista, a não hesitar em reiterar sua predileção pela causa humanista e a demonstrar seus valores em seus textos.

Pereira participou de um projeto de Álvaro Lins sobre a história da literatura brasileira com o livro Prosa de ficção, no qual ela aborda aspectos da evolução da literatura nacional a partir do Romantismo até o Pré-Modernismo, apresentando não 
apenas os autores canônicos, como também os não-canônicos, tais como Valdomiro Silveira, Manuel de Oliveira Paiva, Lindolfo Rocha, entre outros.

O livro foi tão bem recebido em sua época que, sobre ele, Sérgio Buarque de Holanda escreveu em 1950:

Idéias nítidas e despretensiosas, que se podem rastrear através das páginas deste livro e que formam como seu esqueleto invisível. Sendo penhor da acuidade crítica da autora, elas fazem com que esta História não seja, ou não seja apenas, uma narração exaustiva de fatos remotos sem relação clara com a vida atual ${ }^{5}$.

Merece destaque sua crítica ao movimento regionalista de 30, ao qual foi contemporânea. Pereira elaborou uma análise detalhada do movimento. No entanto, ressentiu-se do tratamento do indivíduo como resultado do meio social, pois, apesar de defender a relação entre literatura e sociedade, acreditava ser imprescindível a caracterização de personagens de maneira universal mais do que local. Segundo a autora, a representação da personagem isolada em seu meio "desvia-se do caminho habitual da ficção", registrar os aspectos particulares do homem brasileiro tais como especificidades locais, problemas sociais isolados e políticos regionais, como também os fatores universais que o compõem dentro do quadro da humanidade pela representação de suas angústias, desejos, aspirações, temores, ou seja, seria investigar "o homem em seu meio - ou contra seu meio - mas vê também $o^{7}$ homem, alguém que por suas reações mais

\footnotetext{
${ }^{5}$ HOLANDA, Sérgio Buarque de. "História da literatura brasileira-1870 1920". In: Banco de dados da Folha de São Paulo. Disponível em: <http://almanaquefolhauol.com.br/sergiobuarque.htm>. Acesso em: 10 mai. 2011.

${ }^{6}$ PEREIRA, Lucia. Prosa de ficção. Belo Horizonte: Itatiaia; São Paulo: EDUSP, 1988. p. 175.

${ }^{7}$ Em itálico no original.
} 
profundas se irmana (...) interessa-se pelos indivíduos especificamente, mas na medida em que se integram na humanidade" ${ }^{\prime}$.

Sua visão do regionalismo compreendia cinco momentos, como afirma em Prosa de ficção, tendo como fio condutor o aspecto universalizante na produção ficcional. O primeiro, que se refere ao período de 1870 a 1880 , caracteriza-se pelo regionalismo exótico e pitoresco, que prioriza os elementos exteriores e a "cor local" e, relegando a abordagem humanística, "desvia-se do caminho habitual da ficção"9. O segundo ocorre no fím do século XIX, ao qual denomina de "o regionalismo puro" cujo enfoque recai no "viver da nossa gente, da parte da população livre de influências e contatos estranhos." Como exemplo de autores deste período, cita o mineiro Afonso Arinos, o paulista Valdomiro Silveira e o cearense Manuel de Oliveira Paiva. No terceiro momento, Pereira registra uma preocupação mais geral do homem, em que "se deu início aos estudos de folclore" ${ }^{11}$, tendo como representantes Simões Lopes Neto, no sul, Oliveira Paiva e Domingos Olímpio, no Ceará, e Lindolfo Rocha, na Bahia.

Depois, destaca Os sertões, de Euclides da Cunha, como um marco, a produção de Alcydes Maya, Roque Calage e Alberto Rangel, cujas narrativas são pontuadas por uma "narrativa (...) mais literária" ${ }^{12}$, baseada em uma apreciação mais do que no uso de uma linguagem objetiva. Finalmente, em 1917, com Hugo Carvalho Ramos começa uma fase que recai nas "intenções denunciadoras"13, em detrimento do descritivismo.

\footnotetext{
${ }^{8}$ Ibid., p. 176.

${ }^{9}$ Ibid., p. 175.

${ }^{10}$ Ibid., p. 177.

${ }^{11}$ Ibid., p. 179.

${ }^{12}$ Ibid., p. 180.

${ }^{13}$ Ibid., p. 182.
} 
No ano seguinte, a obra Urupês, de Monteiro Lobato, supera o caráter pitoresco e exótico, ao dar "a primazia aos tipos humanos"14.

Assim, segundo a crítica, o movimento regionalista registrou uma evolução ao se concentrar em uma abordagem mais universalista, ao priorizar o humano, abdicando de uma visão local para uma mais cosmopolita: "Afinal, fora vencido o grande empecilho do regionalismo - a posição de turista assumida pelos escritores"15.

Ainda com relação à sua atuação como crítica literária, Lucia Miguel Pereira esteve preocupada com as questões estéticas na composição romanesca e do conto. Via no romance uma forma literária que possibilita o registro da realidade, recriada no plano da ficção, minimamente deformada, uma vez que seria impossível a reprodução exata do real. Postulava a construção de uma realidade ficcional capaz de sugerir e remeter o leitor aos fatos cotidianos nos quais as personagens estivessem envolvidas. No ensaio “Poetas e romancistas", publicado em Boletim de Ariel em 1934, ela afirma:

Não perguntamos só por que e para que viver, mas também como viver. As relações do homem, já não só com o universo, mas com o seu semelhante, com a sua família, com o seu meio, são hoje ensombradas de dúvida. As incógnitas se multiplicam, e o romance é, assim, uma equação, uma tentativa para resolvê-las. ${ }^{16}$

Com a produção crítica houve o reconhecimento verdadeiro de seu trabalho.

Em Machado de Assis - estudo crítico-biográfico (1936), por exemplo, a importância da pesquisa da vida e obra do autor lhe concedeu significativo destaque literário, sendo que o livro recebeu, em seu lançamento, o prêmio anual da Sociedade Felippe d' Oliveira.

\footnotetext{
${ }^{14}$ Ibid., p. 182.

${ }^{15}$ Ibid., p. 182.

${ }^{16}$ PEREIRA, Lucia Miguel. A leitora e seus personagens. Rio de Janeiro: Graphia, 2005. p. 52.
} 
Em 1952, é publicado o ensaio "Cinquenta anos de literatura", nos Cadernos de cultura do Serviço de documentação do Ministério da Educação, em que analisa a evolução das diferentes formas literárias pelas quais passou nossa literatura.

Sua contribuição crítica é extensa, indo dos temas educacionais às questões femininas, dos problemas da atualidade aos estudos históricos, etnográficos e sociológicos; ela utiliza uma abordagem interativa com o leitor, em um estilo requintado, mas não pedante, baseado no respeito ao autor e na visão da análise crítica como um modo de "compreender e respeitar as opiniões alheias"17.

$\mathrm{O}$ artigo "O Ofício de Compreender", publicado na Gazeta de Notícias em 1934, pode ser avaliado como um texto de fundamental importância do legado crítico da autora, pois conclama ao esclarecimento sobre a função social da literatura e da crítica. Ele também trata dos posicionamentos ideológicos, do compromisso do intelectual na sociedade e, por fim, da responsabilidade do crítico na articulação de um sistema intelectual.

Um trabalho substancial da autora nesse ensaio foi a elaboração de comentários sobre um jornal francês que promoveu uma enquete acerca das relações entre a coisa pública e a coisa literária, cuja pertinência foi destacada por ela, particularmente por vivenciar uma época de transição, a Era Vargas. De acordo com a autora, tais épocas "são também, fatalmente, épocas de revisão, de julgamento"18. A palavra julgamento sublinha a importância atribuída pela autora à capacidade crítica movida pela inteligência, pelo intelecto. Em suas próprias palavras: "Quando tudo ameaça ruir, o

\footnotetext{
${ }^{17}$ Ibid., p. 52.

${ }^{18}$ Ibid., p. 89.
} 
exame das bases se impõe; e quem competirá, senão a inteligência? Chamada assim a verificar, a escolher, a decidir, ela não pode ficar alheia às preocupações sociais [...]"19 .

No tocante à função social da literatura, Lucia Miguel Pereira explicita o que entende por sentimento de inserção no mundo:

De par com as misérias de que tanto nos queixamos, trouxe-nos o nosso tempo alguns bens, de que nunca falamos; e o maior é sem dúvida este de nos obrigar a refletir, a viver conscientemente, a reconhecer a estreita interdependência dos valores; a sentir a gravidade e a solidariedade das idéias; a ver que não existem divisões estanques entre a vida especulativa e a vida prática, que a coisa literária e a coisa pública se encontram e se confundem no seu grande palco comum: a coisa humana. (...) Daí a alta significação, e a responsabilidade da literatura ${ }^{20}$.

Para a autora, as transformações da sociedade se iniciam pelo pensamento reflexivo, uma vez que tais mudanças são resultados da capacidade crítica de se estabelecer um julgamento, tendo a literatura não só como meio, mas também como agente.

Outro tema comentado nesse mesmo artigo aborda a relação entre o meio e o escritor, ressaltando a recíproca troca de influências entre o ambiente social e o espírito individual do criador literário. Neste momento, Lucia Miguel Pereira faz uma clara alusão a Outubro de 1917 e apresenta as duas vertentes político-ideológicas, a direita e a esquerda, nas quais as sociedades estavam se agrupando "sobretudo desde que uma revolução vitoriosa nos veio lembrar a ação da vontade humana nos acontecimentos"21. É também interessante mencionar que essa reflexão acerca da relação do escritor com seu meio levou a escritora a questionar sua própria formação católica, ao fazê-la indagar

\footnotetext{
${ }^{19}$ Ibid., p. 89.

${ }^{20}$ Ibid., p. 89-90.

${ }^{21}$ Ibid., p. 90.
} 
até que ponto a crença religiosa que professava e a posição social a qual pertencia estavam alheias aos acontecimentos da sociedade.

Posteriormente, Antonio Candido também ressaltaria essa relação entre a produção literária e a sociedade, na obra Literatura e sociedade, na qual afirma sua íntima relação: “(...) a arte é social nos dois sentidos: depende da ação de fatores do meio, que se exprimem na obra em grau diversos de sublimação; e produz sobre os indivíduos um efeito prático, modificando a sua conduta e concepção do mundo, ou reforçando neles o sentimento dos valores sociais" ${ }^{\text {22 }}$. Embora Pereira reconheça a relação entre o meio e a obra, de acordo com sua visão, o texto literário não se destina "aos interesses de uma causa" 23 , não pode ter uma feição doutrinária, mas conduz a uma reflexão sobre a realidade circundante.

Ainda por meio desse mesmo texto, Lucia Miguel Pereira cita a presença de dois romancistas brasileiros, Jorge Amado e Octávio de Faria, aos quais endereça adjetivos que nos remetem à percepção do que seja a relação entre a coisa pública e a coisa literária: "Inovadores como Jorge Amado, conservadores (no sentido largo) como Octávio de Faria, quase todos se definem e são apreciados não somente pelas suas qualidades literárias, como ainda pelas suas convicções"24.

Pereira confere importância tanto ao valor ideológico da reflexão no fazer literário quanto ao estilo, ou seja, reconhece a importância do trabalho literário, no sentido de o autor assumir um posicionamento. Em seus ensaios, a crítica expressa claramente suas ideias, embora não concorde que um texto espelhe qualquer doutrina: “O escritor é julgado menos pelo seu estilo do que pelo que tem a dizer. Não se espera

\footnotetext{
${ }^{22}$ CANDIDO, Antonio. Literatura e sociedade. São Paulo: Companhia Editora Nacional, 1980. p. 20-21.

${ }^{23}$ PEREIRA, Lucia. op. cit., p. 100.

${ }^{24}$ Ibid., p. 90.
} 
dele apenas que distraia o espírito, mas, sobretudo que o faça pensar. O pensamento é que vale, da sua sinceridade dependerá quase totalmente o valor da obra"25.

Porém, essa relevância das ideias não relega a estética a um segundo plano, ao contrário, a autora nos diz que a emoção estética "é produzida pelo equilíbrio entre o fundo e a forma; vem do conjunto, da harmonia global, e não do vocábulo retumbante e sonoro" 26 . A partir desse ponto, vão-se alinhando definições sobre o papel da crítica e a função daquele que a exerce na sociedade - cabe ao crítico ter a habilidade de unir a preocupação social, uma vez que ele é produto do meio no qual vive, à elaboração de um texto que expresse seu pensamento da forma mais adequada: "Usando de linguagem matemática, podemos dizer que ela (a crítica) está para a literatura como está para a sociedade. A proporção é a mesma, a mesma dependência" ${ }^{27}$. A mesma ideia é reafirmada na seguinte passagem:

O crítico é um escritor sem imaginação que necessita do choque do pensamento alheio para fecundar o seu, mas é um escritor. E por isso está preso às influências do meio; vem dele e por essa passividade do seu feitio mental estará talvez ainda mais sujeito do que os outros à sua dominação. Não pode sem pretensão ridícula assumir atitudes de juiz $^{28}$.

Ainda no mesmo artigo, sobre a atitude do crítico, Lucia Miguel Pereira é reiterativa quando destaca a postura conciliatória: ele é "quando muito um marco indicador, procurando encaminhar, não a corrente dos conceitos, mas o entendimento destes. Deve isso sim, buscar compreender, compreender as diretrizes de cada autor, a contribuição de cada obra". ${ }^{29}$ Isso se deve ao fato de o profissional não estar isolado e

\footnotetext{
${ }^{25}$ Ibid., p. 90.

${ }^{26}$ Ibid., p. 90-91.

${ }^{27}$ Ibid., p. 91.

${ }^{28}$ Ibid., p. 91.

${ }^{29}$ Ibid., p. 91.
} 
sim buscar seu público, como o escritor, e junto a ele exercer influência: "Nessa compreensão, nessa simpatia, está a sua razão de ser, só através delas logrará influir sobre a opinião" 30 .

Em outro trecho afirma: “O crítico (...) terá o direito de sobrepor as suas preferências pessoais às do escritor? Não deverá procurar colocar-se por um momento no ponto de vista deste, para melhor entendê-lo?"31. O artigo termina com uma condenação à vaidade do crítico, vaidade esta sempre menos importante que a sinceridade da "simples explicação"32 do julgamento. Além disso, apresenta um chamamento à convivência de diferentes opiniões: "A compreensão é o grande dom da inteligência, o que a livra da esterilidade do cerebralismo, e a torna quase tão profunda quanto o sentimento"33.

Assim, Lucia Miguel Pereira vê o papel do crítico como uma pessoa compreensiva, conciliatória, que interage com o meio, livre de qualquer julgamento e autoritarismo.

A autora também questiona a crítica elaborada a partir de pontos de vista, em uma clara alusão à oposição entre a abordagem impressionista e a objetiva:

Aí reside a grande dificuldade da crítica sempre subjetiva em seus julgamentos, pois estes são, afinal, o resumo das reações provocadas por uma obra num determinado espírito; e obrigada, entretanto, por lealdade, a tentar ser a mais objetiva possível na sua compreensão ${ }^{34}$.

A questão de uma crítica voltada para opiniões pessoais no processo de elaboração da crítica merece especial atenção. Lucia Miguel Pereira viveu na época do

\footnotetext{
${ }^{30}$ Ibid., p. 91.

${ }^{31}$ Ibid., p. 91.

${ }^{32}$ Ibid., p. 92.

${ }^{33}$ Ibid., p. 92.

${ }^{34}$ Ibid., p. 91.
} 
advento da Nova Crítica, introduzida no Brasil por Afrânio Coutinho. No livro do autor, Da crítica e da nova crítica, ele nos apresenta os pressupostos dessa tendência crítica, a qual se interessa pelos aspectos estéticos e investigativos, no sentido de delimitar a natureza e a função da literatura. Valendo-se das pesquisas de novos métodos de abordagem e análise literária, tem como premissa a multidisciplinaridade e a utilização de critérios para a compreensão textual. Sua preocupação precípua é o estabelecimento de princípios que normatizem as análises do crítico literário, ou seja, uma metodologia, o que lhe confere um caráter cientificista. Assim, propõe a interpretação do tex to a partir de um enfoque calcado em critérios literários, além daqueles outros advindos de várias áreas do conhecimento, tais como a psicologia, a antropologia, a linguística etc.

Segundo o autor, apenas alguns escritores não necessitaram desses pressupostos analíticos, isto é, utilizaram somente seus pontos de vista em suas leituras críticas. Por essa razão, ele os denominava metaforicamente de "esotéricos", isto é, um grupo especial de iniciados, que não precisavam de qualquer procedimento metodológico para suas análises literárias. Este grupo, então, caracteriza a crítica impressionista sustentada pelos valores e gostos pessoais mais do que qualquer atitude investigativa baseada em uma metodologia: "A crítica impressionista - claro que o verdadeiro impressionismo, o de um France, um Pater, uma Virginia Woolf, não o seu filho bastardo, o comentarismo [...] ${ }^{, 35}$. Trata-se de um tipo de análise literária, enfim, que “[...] - só é acessível a uns poucos espíritos superiores, dotados de sensibilidade artística refinada $[\ldots]]^{, 36}$.

A visão de Coutinho sobre a crítica impressionista apresenta duas vertentes: se, por um lado, é positiva em relação a um grupo especial de escritores que são bem-

${ }^{35}$ COUTINHO, Afrânio. Da crítica e da nova crítica. Rio de Janeiro: Civilização Brasileira, 1957. p. 100.

${ }^{36}$ Ibid., p. 100-101. 
sucedidos ao fazer suas críticas, por outro, os que não são "iniciados" podem desenvolver uma análise sem critérios lógicos. Nesse momento, a crítica impressionista é avaliada negativamente e condenada, como comenta em sua obra Caminhos do pensamento crítico:

O crítico impressionista não pode julgar - que é a finalidade da crítica, mas somente pronunciar opiniões ou emitir impressões. Seu critério de apreciação é o do gosto, apurado ou não... Em plano mais baixo, a crítica impressionista, porque lhe falecem critérios objetivos, reduz-se a opiniões, no fundo comparáveis à fórmula do gostei - não gostei, ou do 'achismo' $[\ldots]^{37}$.

A Nova Crítica para Coutinho, diferenciada da crítica impressionista, é entendida como uma abordagem, uma disciplina autônoma, multidiscursiva e não como um sistema de regras para a análise textual.

A base cientificista apregoada por ele é apenas um conjunto de critérios de análise, comum a todos os leitores críticos. Na verdade, a Nova Crítica é uma disciplina autônoma que se utiliza de várias outras disciplinas e de pressupostos analíticos: "A nova crítica não é apenas um instrumento de análise. É todo um conjunto de idéias e princípios, no plano da estética geral e da doutrina literária; no plano da estética particular dos gêneros; e no plano da análise e do método de investigação" ${ }^{\text {\#8 }}$. Seus praticantes ressaltam ainda que seu caráter científico favorece a propagação do conhecimento numa atitude "democrática", no sentido de apresentar e disseminar uma sistematização de investigação comum a todos os leitores críticos, e não apenas restrita a um determinado grupo: "O que se pretende ao reivindicar para a crítica um substrato

\footnotetext{
${ }^{37}$ COUTINHO, Afrânio. Caminhos do pensamento crítico. Rio de Janeiro: Pallas, 1972. p. 651-652.

${ }^{38}$ COUTINHO, Afrânio. op.cit., p. 98.
} 
científico não é torná-la esotérica (...) Ao contrário, a ciência comunicará à crítica um denominador comum, acessível a quem se disponha somente a aprender "39.

Mais recentemente, em "Crítica literária no Brasil, ontem e hoje", Benedito Nunes discute a questão afirmando que Lucia Miguel Pereira não era uma crítica impressionista. Não só a ensaísta brasileira, mas também alguns de seus companheiros intelectuais como, por exemplo, Álvaro Lins, Alceu de Amoroso Lima, Afrânio Coutinho e Sérgio Buarque de Holanda eram "avessos ao impressionismo" 40.

Concordamos com Nunes, no sentido de que Pereira não é realmente uma crítica impressionista, uma vez que argumenta baseada em parâmetros literários quando analisa a concepção de romance em relação à personagem, ao tempo e espaço. Há uma metodologia de leitura bem estabelecida, o que poderia aproximá-la da Nova Crítica em sua concepção cientificista, ou seja, uma leitura criteriosa não baseada somente em opiniões. Como a Nova Crítica não é apenas um sistema metodológico, mas uma disciplina autônoma, multidiscursiva, a autora brasileira, por sua vez, não se enquadraria nessa concepção ao desaprovar a intervenção de outras áreas do conhecimento na análise literária, como afirma no ensaio "Crise da Europa ou crise do espírito" (1935), em relação aos críticos de seu tempo:

E como a época é dos técnicos, pedimos emprestado à mecânica, à física à geometria, à psiquiatria, os seus termos. (...) Se não falar em ângulo, incidências, entropia, dinamismo, reflexão, esquizofrenia e recalques a coisa não fica com aparência profunda ${ }^{41}$.

Portanto, se decididamente ela não é uma crítica impressionista, porque possui uma metodologia de leitura baseada em critérios da teoria literária, podemos dizer que

\footnotetext{
${ }^{39}$ Ibid., p. 101.

40 NUNES, Benedito. Crítica literária no Brasil, ontem e hoje. In: Rumos da Crítica. São Paulo: SENAC/Itaú Cultural, 2000. p. 59.

${ }^{41}$ PEREIRA, Lucia Miguel. A leitora e seus personagens. Grafia: Rio de Janeiro, 2005. p. 38.
} 
ela também não pertence à Nova Crítica, na medida em que não concorda com o caráter científico, a multidisciplinaridade e o julgamento crítico, que caracteriza a abordagem: ela apenas aceita o discurso da teoria literária, tendo por fio condutor o processo reflexivo do crítico.

O conceito de crítica é ainda explorado por Lucia Miguel Pereira em outro artigo, "Crítica e controvérsia", publicado na Revista do Brasil em 1939, sobre um livro de ensaios do crítico português João Gaspar Simões, em que enfatiza a questão da elaboração crítica. Já na introdução desse artigo, faz um elogio da crítica consagrando-a como a expressão mais adequada e justa à inteligência: "a pedra de toque da boa crítica é obrigar a refletir, é ser atual como um estimulante do raciocínio; o seu domínio próprio é a controvérsia" 42 .

Como era comum em sua época de atuação, seus ensaios foram veiculados em vários periódicos, inclusive entre os anos 30 e 40, década decisiva para a afirmação do romance, da poesia e do ensaísmo brasileiros. Entre eles, a Revista do Brasil e o Boletim de Ariel eram de tendência internacionalista e liberalizante. Também colaborou em A Ordem e Lanterna Verde, cujas posições eram mais comedidas, quando não claramente conservadoras. Ainda na esteira das publicações críticas, Pereira escreveu para a Gazeta de Notícias, um jornal informativo, e no Correio da Manhã, um periódico de forte militância política vítima de duras investidas da ditadura do Estado Novo (1937-1945).

De 1943 a 1959 trabalhou para O Jornal (Rio de Janeiro), O Estado de São Paulo, O Estado de Minas e Diário de Pernambuco, além da revista Literatura, em

\footnotetext{
${ }^{42}$ Ibid., p. 92.
} 
1946, em que analisa obras de seus contemporâneos e faz um trabalho comparativo entre Machado de Assis e Lima Barreto.

A prática literária no ambiente jornalístico era usual no fim do século XIX, uma aproximação considerada como um benefício tanto para os jornais quanto para os escritores, pois os temas abordados iam ao encontro das expectativas do público leitor, em expansão nesse período. Na obra dedicada a esse convívio, Imprensa e espaço público, Lavínia Madeira Ribeiro comenta sobre esse período:

O jornalismo cultural procurou, de certa forma, tematizar experiências até então não atingidas pela discursividade pública política. Críticas literárias, resenhas, ensaios, polêmicas de longo curso sobre o que deveria ser considerado como próprio à nacionalidade brasileira (...) a reprodução de poemas, de contos e romances entre tantas manifestações específicas do fazer literário tiveram espaço integral nas páginas do jornalismo fluminense da época. Eram padrões oriundos da literatura incorporados sem mutilações pela imprensa tornando-a, cada vez mais, a instância que conferia maior visibilidade pública às práticas literárias ${ }^{43}$.

Pereira também escreveu ensaios que refletem seu posicionamento político, como, por exemplo, "Entre Pascal e Panurgio", publicado em Boletim de Ariel, em 1936:

Armam o dilema com a maior simplicidade: Roma (não a Roma do Papa, mas a de Mussolini) ou Moscou. Direita, isto é, governo totalitário, forte para lutar contra a anarquia, ou esquerda, isto é, a revolução materialista e destruidora de todo o passado. O humanismo biológico dos racistas ou o humanismo mecanicista dos soviets. E daí não há como fugir ${ }^{44}$.

Essa divisão, segundo a autora, é causada por um irracionalismo que não condiz com as características intrínsecas do ser humano: a reflexão e a liberdade. No mesmo ensaio, Pereira afirma:

\footnotetext{
${ }^{43}$ RIBEIRO, Lavínia. Imprensa e espaço público. Rio de Janeiro: E-paper. p. 172.

${ }^{44}$ PEREIRA, Lucia Miguel. A leitora e seus personagens. Rio de Janeiro: Grafia, 2005. p. 42.
} 
Como se o mundo estivesse dividido em dois compartimentos estanques, de modo que quem escapasse de um cairia fatalmente no outro. Fatalidade que dispensaria de pensar, refletir, de escolher em conhecimento e causa. Irracionalismo gerando um automatismo que despede a inteligência, o pensamento, e reflexão como coisas inúteis, sobreviventes caducas de épocas mortas ${ }^{45}$.

A fim de resolver tal dicotomia, propõe a reflexão a partir da exaltação da liberdade do homem de "ser bom, de simpatizar, de compreender": "Mas o verdadeiro dilema dos nossos dias não estará em se conformar, marchar com o rebanho, e trair o espírito, ou em não se conformar, não abdicar das prerrogativas mais nobres da nossa pessoa humana e ter a coragem de pensar?" ${ }^{46}$.

Diante desse dilema a autora escolhe a segunda opção, pois defende uma atitude humanista que lute por um ideal e propõe uma atitude racional diante desse irracionalismo, visto como reducionista da potencialidade da natureza humana.

Aliás, o título do ensaio já nos remete a uma dicotomia ao referir-se ao pensador Pascal e a Panurgio, uma personagem de Rabelais do livro Pantagruel, que faz seu inimigo morrer ao tentar salvar suas ovelhas no mar, ou seja, não raciocina que estava sendo induzido à morte. Assim, a crítica brasileira antepõe a reflexão (Pascal) à imagem da servidão (Panurgio), para demonstrar a importância da capacidade humana de pensar para não ceder ao jugo de outrem.

Outro tema abordado por Pereira refere-se ao seu posicionamento sobre o avanço tecnológico mencionado no ensaio "Crise da Europa ou crise do espírito?”: "A passagem do instrumento à máquina foi a verdadeira origem da revolução a que

\footnotetext{
${ }^{45}$ Ibid., p. 42.

${ }^{46}$ Ibid., p. 44.
} 
assistimos e a adaptação às formas de vida decorrentes do novo estado de coisas constitui a crise fundamental da nossa época" ${ }^{97}$.

A autora brasileira faz uma crítica ao seu tempo, cuja sociedade passava por uma transformação tecnológica em detrimento da valorização do ser humano. Desse modo, o ensaio ironiza esse progresso material, focando a crítica na linguagem tecnicista em contraponto à linguagem literária.

A mudança da sociedade em que viveu a autora corresponde à transição de um ambiente quase rural, pré-industrial e provinciano da Velha República (1889-1930) para uma sociedade cosmopolita e foi por ela demonstrada em Prosa de ficção (1870 a 1920), obra que lhe rendeu o reconhecimento definitivo como crítica literária.

Ali, a crítica faz um paralelo entre os movimentos literários e suas respectivas sociedades, evidenciando a importância que atribui à relação entre a sociedade e a literatura, como um comprometimento entre a realidade e a ficção. Lucia Miguel Pereira, nesse livro, observa que tal vínculo foi alterado pela crescente industrialização, o que ocasionou modificações no modo de vida da população, e como consequência "sofria a ficção outra grande mudança: de rural que fora sobretudo até então, tornava-se predominantemente citadina"48.

Essa transformação que ocorreu na literatura foi o reflexo da passagem de um ambiente predominantemente rural para o urbano, devido a um crescente processo de industrialização já na época da Primeira República (1889-1930), que iria se consolidar no governo de Getúlio Vargas devido à crise no setor cafeeiro e à necessidade do

\footnotetext{
${ }^{47}$ Ibid., p. 39-40.

${ }^{48}$ PEREIRA, Lucia Miguel. Prosa de ficção. Belo Horizonte: Itatiaia/São Paulo: EDUSP, 1988. p. 30.
} 
aumento de exportações causada pela crise mundial de 1929 e pela Segunda Guerra Mundial.

A crítica acreditava ser a era tecnológica uma forma de desumanização, no entanto, não era contra as máquinas que ela levantava sua voz, mas sim contra o poder exacerbado do homem na sua má utilização. Sua preocupação com a abordagem humanista era tal que mesmo essa nova realidade social poderia tirar proveito dos benefícios de suas mudanças a partir do momento em que a técnica fosse utilizada para o bem-estar do indivíduo.

Essa questão foi abordada no artigo "O sonho e a máquina” de 1935, publicado em Boletim de Ariel:

Foi a ambição dos homens que transformou numa fonte de males o que deveria ser uma distribuidora de bens. A máquina será o que for o homem que a dirige... A luta não é entre o homem e a máquina, mas entre o homem e o homem para ver de que lado ela ficará, se com o capital, se com o trabalho ${ }^{49}$.

Ao assumir esse posicionamento sobre a relação entre o homem e a máquina utilizada como metáfora do crescente processo industrial, ela opta por uma produção artística vinculada à realidade, que concebe a literatura como um reflexo de seu tempo. Além disso, tem uma atitude corajosa ao defender a necessidade da reflexão crítica sobre a ligação da política com a tecnologia em uma época marcada pelo início da industrialização brasileira e pelo controle à liberdade de expressão.

O artigo de Lucia Miguel Pereira também prevê as sociedades adiante de seu tempo ao fazer uma advertência sobre o modo como o homem se relaciona com o progresso, que, na realidade, é positivo, se souber como administrá-lo para o seu bem-

\footnotetext{
${ }^{49}$ PEREIRA, Lucia Miguel. A leitora e seus personagens. Rio de Janeiro: Grafia, 2005. p. 37.
} 
estar. Assim, Pereira expressa um impasse sobre os prós e os contras do desenvolvimento tecnológico:

Não só nas suas aplicações desportivas, mas também nas industriais, ela (a máquina) veio libertar o homem. Se o capital a explora, e se recusa a ver nela uma serva do operário, é que desconhece o seu verdadeiro sentido. A sua finalidade profunda não é centuplicar o rendimento, mas facilitar a tarefa e permitir destarte ao trabalhador horas para viver a sua vida de ente livre ${ }^{50}$.

Essa preocupação humanística relacionada à posição do trabalhador na engrenagem da sociedade, além de ser fruto da formação católica, como dito anteriormente, também se coaduna com a mudança de mentalidade do conceito de cidadania promovida pela Revolução de 30. Sobre essa questão, em Estado Novo Ideologia e Poder, Lúcia Lippi comenta:

Até 1930 podia-se dizer que 'o governo do Brasil não era para o povo, mas para seus representantes', que jamais se lembraram de 'chamar as classes operárias a participar da sorte' do país e que jamais pediram 'os esforços dos trabalhadores, procurando interessá-los nos problemas vitais da nossa emancipação econômica ${ }^{51}$.

A nova forma de governo fomentada na revolução de 30 e concretizada em 1937 no estabelecimento do Estado Novo caracterizou-se por uma preocupação com o homem em sua dimensão total, ou seja, material e espiritual. As novas elites políticas mobilizaram as massas, a fim de retomar a construção de um verdadeiro espírito de nacionalidade caracterizado pela importância dos valores humanos e cristãos. Porém, essa valorização do humano foi uma estratégia utilizada pelos fomentadores da Revolução de 30 para inculcar nos cidadãos a noção de um Estado preocupado com a justiça social, em que o trabalho a favor da sociedade assume um papel essencial.

\footnotetext{
${ }^{50}$ Ibid., p. 37.

51 OLIVEIRA, Lúcia Lippi, VELloso, Mônica Pimenta, GOMES, Ângela M. Castro. Estado novoideologia e poder. Rio de Janeiro: Zahar, 1982. p. 117.
} 
Para atingir esse objetivo é estimulada a prioridade do interesse coletivo sobre a liberdade individual, sob o comando de uma autoridade ordenadora do meio social. Dessa maneira, forjou-se a situação propícia ao aparecimento da figura de Getúlio Vargas como um líder para exprimir a vontade popular a fim de assegurar o bem-estar da nação. Ou seja, é instituído um regime autoritário sobre as bases de um projeto democrático, em que o trabalhador aparece como um cidadão de um novo tipo de democracia - a democracia social.

Tal contexto político vai de encontro às idéias de Pereira que, em outro ensaio, "Romance de tese e individualidade", publicado na Gazeta de Notícias em 1934, volta a enfatizar a individualidade do trabalhador em oposição à massificação:

A mística populista, vendo a massa e não o indivíduo, dá do trabalhador uma imagem falsa. Há nele um fundo de doçura, uma necessidade ingênua de beleza, de ideal, quase de pureza, de que se esquecem os seus idólatras no seu empenho de descobrir-lhe a amargura, a revolta. Elas existem e nem poderiam deixar de existir. Mas são uma face, apenas, a face que apresentam sobretudo as multidões, cuja psicologia é muito diversa da individual ${ }^{52}$.

Essa orientação humanista também a levou a refletir sobre a condição social da mulher em seu tempo. Como mencionado anteriormente, a crítica brasileira, desde o começo de sua produção literária, preocupou-se com as questões femininas. Essas aparecem, por exemplo, no artigo "O problema feminino", publicado na Revista Elo, em que questiona a educação feminina baseada na afetividade, o que representaria a nãoinserção da mulher na sociedade de forma intelectualmente participativa. Defende, para a mulher, outra diretriz em termos de formação humana, ou seja, uma norma que subjaza à educação pela constituição do intelecto e da reflexão crítica, portanto, algo a mais do que uma mulher voltada apenas para a emoção.

\footnotetext{
${ }^{52}$ PEREIRA, Lucia Miguel. A leitora e seus personagens. Rio de Janeiro: Grafia, 2005. p. 102.
} 
Esse posicionamento de Pereira parece-nos pertinente na medida em que à mulher não era, entre outras questões, facultado nem o direito ao voto, isto é, era-lhe negado um direito dos mais básicos na construção da cidadania e da participação civil. Para além de uma atitude política, o voto também representa um posicionamento intelectual do indivíduo que o utiliza, uma vez que traduz idealmente uma escolha baseada na informação, no questionamento, na capacidade e na liberdade de escolha e, por fim, na responsabilidade de uma tomada de decisão.

Lucia Miguel Pereira sente a necessidade da mudança de foco em relação à educação feminina, desarticulando a formação de um ser meramente frágil e apenas afetivo para articular a construção de um ser social com direitos e deveres civis, consciente de sua existência por meio da reflexão intelectual.

Por essa atitude ela se posicionou como uma pioneira na crítica literária de sua época. Em relação a esse vanguardismo, Márcia Cavendish Wanderley ressalta no artigo "A primeira crítica da literatura brasileira", publicado no Jornal do Brasil: "Muitas se arriscaram e algumas até desafiaram o poder masculino em território até então proibido: o da crítica literária. A primeira a conquistar ali algum espaço chama-se Lucia Miguel Pereira $[\ldots]^{, 53}$.

Pode ser considerada uma precursora da crítica literária feita por mulheres, embora seu foco tenha sido principalmente a análise de obras de escritores do sexo masculino, pois a produção literária feminina brasileira apresentava-se de forma incipiente em sua época. Tal tipo de crítica só prosperaria a partir de meados do século $\mathrm{XX}$, com o advento do movimento feminista e um consequente aumento no número de escritoras.

\footnotetext{
${ }^{53}$ CAVENDISH, Márcia Wanderley. A primeira crítica literária brasileira. O Estado de São Paulo, São Paulo, p. 4, 29 dez. 2001.
} 
Com relação à produção literária feminina no Brasil, a autora publicou em 1954, na revista Anhembi, um ensaio, "As mulheres na literatura brasileira", no qual elenca uma série de escritoras que vivenciaram a indiferença dirigida às mulheres. Nesse texto Pereira elucida o nível de opressão à qual eram submetidas as mulheres no Brasil, não apenas as solteiras, mas também as casadas, que em alguns casos chegavam a ser "trancafiadas em conventos quando os maridos viajavam",54. Ao expor a condição da mulher, a crítica ratifica seu empenho a favor da emancipação feminina e ainda refere-se à liberdade, um tema recorrente em sua produção ensaística: “Anjos do lar ou inquietantes filhas de Eva, não se lhes podia conceder a menor independência” ${ }^{\text {"55 }}$. Nessa passagem, a menção aos "anjos do lar" remete-nos ao termo "angel in the house", que caracteriza a mulher confinada ao âmbito familiar.

Essa expressão originou-se de um poema homônimo de Coventry Patmore (1823-1896), publicado em 1854, em homenagem a sua esposa, Emily Patmore (18241862), e descreve a corte e o casamento de um jovem casal. O poema é a expressão completa da idealização da mulher, pois o anjo é apresentado como mais puro que Eva, porém não é somente inocente - ele exerce poderes sutilmente. Ele marcou fortemente a visão da mulher na Inglaterra, colocada em um plano inferior ao homem, restrita ao universo familiar ${ }^{56}$.

No Brasil ocorria uma situação semelhante: à mulher era vedado o direito de cidadania e de uma atuação fora da atividade doméstica. No começo do século XX, não lhe era concedido o direito de voto e, nesse sentido, estava alinhada aos mendigos e analfabetos. Essa condição impulsionou o começo do movimento feminista brasileiro, cujo foco estava centrado na participação das mulheres como candidatas e eleitoras,

\footnotetext{
${ }^{54}$ Ibid., p. 20.

${ }_{55}^{5}$ PEREIRA, Lucia Miguel. As mulheres na literatura brasileira. Anhembi, São Paulo, p. 24, dez. 1954.

${ }^{56}$ Virginia Woolf discutirá essa figura.
} 
lideradas por Bertha Luz, uma das expoentes do movimento sufragista, que alcançou seu objetivo em 1932.

Pereira termina seu artigo declarando não ser feminista, corroborando o que se disse anteriormente, no sentido de que sua produção ensaística concentrou-se nos escritores homens: "Não sou feminista, nunca o fui, e já agora nem caberia sê-lo, que não resta muito a reivindicar, mas força é reconhecer que tinha razão Virginia Woolf, quando, em “A room of one's own”, reputava o mundo da cultura um mundo masculino, do qual se viam excluídas as mulheres" grande número de escritoras, como Júlia Lopes de Almeida, Cecília Meireles, Gilka Machado, Carmen Dolores, Henriqueta Lisboa e Dinah Silveira de Queiróz, sua crítica não é voltada para elas. Com exceção de Júlia Lopes Almeida, as obras das escritoras não são objeto de sua análise (pelo menos não no material compilado depois de sua morte).

Enfim, a atuação de Lucia Miguel Pereira em relação à crítica literária foi ampla e altamente significativa, na medida em que sua presença se fez sentir em diversas áreas do pensamento e sempre de modo muito objetivo, pontual e com um forte embasamento teórico ao expor suas idéias, o que justifica a repercussão de seus textos até os dias de hoje nos estudos de teoria literária.

\footnotetext{
${ }^{57}$ Ibid., p. 24.
} 


\section{A intelectual católica}

Vários fatores nortearam a produção literária de Lucia Miguel Pereira como romancista, ensaísta e crítica literária. Ela atuou em grupos católicos como o da revista A Ordem juntamente com Antônio de Alcântara Machado, Jorge de Lima, Sérgio Buarque de Hollanda, entre outros. Daí ter recebido a denominação de "intelectual católica". Foi muito importante para a autora o apoio deste grupo, principalmente para sua consolidação como escritora no começo de sua carreira. Após os anos 30, a influência católica já se reduziu tanto na esfera doutrinária quanto na sua vida pessoal, pois uniu-se a um homem desquitado, o que era um ultraje segundo os princípios de sua época.

A revista $A$ Ordem, meio de divulgação de idéias de correntes espiritualistas europeias, e o Centro Dom Vital, no Rio de Janeiro, representaram a intelectualidade a serviço da Igreja, a partir da concepção de reconstrução de um Estado cujas bases se assentassem na valorização social, política e religiosa. Aliás, o título da revista é significativo, no sentido de indicar a busca pelo fortalecimento da família, da pátria e da religião. O Centro Dom Vital foi de fundamental importância para a implantação do projeto católico, pois congregava a intelectualidade preocupada com o futuro políticoreligioso do Brasil. Tanto a revista como o Centro Dom Vital foram estruturados por Jackson de Figueiredo, mais voltado para as questões políticas, e Alceu Amoroso Lima, cuja orientação tinha um caráter mais cultural.

Formou-se uma estreita colaboração entre Igreja e Estado, que contemplava a formação da Liga Eleitoral Católica, fundada por Dom Leme, cujo objetivo era orientar os religiosos sobre os direitos e deveres do cidadão, e destacava a importância do voto 
para mudanças sociais. Essa relação entre religião e política pode ser exemplificada em um excerto do jornal A Ordem, de 1932: "A família brasileira, as estatísticas attestamno (sic), é verdadeiramente catholica (sic) e como a família, e não mais o indivíduo, é considerada, hoje em dia, pelos sociólogos de todos os credos humanos, como a base, o núcleo da nacionalidade, a nação brasileira é, em sua quase unanimidade, eminentemente catholica" 58 .

A Ordem era um veículo de difusão de idéias ligadas à tradição e dos valores espirituais dos quais, segundo seus fundadores, a sociedade estava afastada, composta de artigos escritos por homens, abordava problemas sociais e políticos contemporâneos. Somente a partir de 1932, ou seja, após onze anos de sua fundação, a presença feminina começou a aparecer em publicações com temas relativos ao universo feminino. Essa novidade constitui um dado importante, na medida em que revela a consideração do aumento da importância da presença feminina no contexto social.

Lucia Miguel Pereira foi participante do Centro Dom Vital e colaboradora nessa revista e depois passa por um progressivo desprendimento com relação aos conceitos religiosos e moralizantes que cerceavam sua obra literária.

Dentre as várias crônicas escritas por Pereira, destacaremos as "Crônicas femininas", em que estão delineados e valorizados os papéis tradicionais da mulher na família e na sociedade. Em 1933, a autora afirma:

O ciclo de vida normal e honesta da mulher tem de se processar dentro dos limites a um tempo apertados e imensos da maternidade. Tudo o que a tira daí é uma transgressão das leis naturais. A sua ação social, se tiver de ser ampliada só o pode ser dentro desse quadro ${ }^{59}$.

\footnotetext{
${ }^{58}$ A Ordem. Ano XII, n. 32, p. 250, out. 1932.

${ }^{59}$ A Ordem. N. 39-40, p. 433-434, mai./jun. 1933. Atualizamos a linguagem utilizada.
} 
Nas crônicas da revista, a crescente influência do liberalismo era mal vista, uma vez que se relacionava a valores como o individualismo feminino, considerado uma afirmação de egoísmo. Nessa mesma crônica, Pereira comenta:

(...) formar mocinhas que, mal saídas dos colégios sonham ser datilógrafas para obterem uma maior liberdade financeira e mesmo uma maior liberdade, "tout court", não é prepará-las para a vida. Ao contrário. A educação que visa a felicidade egoísta da mulher pode acarretar a sua desgraça ${ }^{60}$.

Essa rejeição ao individualismo e uma visão mais abrangente, universalizante, não só com relação à mulher, constituem um ponto de vista importante em sua crítica literária posterior com relação à produção romanesca, o qual será objeto de discordância com o movimento regionalista da década de 30 .

O objetivo era preparar adequadamente a mulher, fato visto como muito importante para a realização do projeto católico no Brasil. Em outra crônica percebemos esse direcionamento nas palavras de Lucia Miguel Pereira: "A maior liberdade de movimentos, de leituras, de conversas, não é em si um mal. A menina de hoje, cedo instruída das coisas da vida (...) pode (...) se manter tão digna, tão pura como a antiga" $"$.

Mesmo em seu trabalho biográfico sobre Machado e Assis, notam-se resquícios de sua formação católica. Na fatura da obra, empenhou-se em escrever uma biografia que fugisse dos padrões convencionais, atendo-se a aspectos psicologizantes sobre a vida do escritor brasileiro a fim de realizar uma "biografia do seu espírito". Como exemplo de sua visão crítica, em uma passagem em que é questionada a religiosidade do autor, afirma:

\footnotetext{
${ }^{60}$ Ibid., p. 454.

${ }^{61}$ A Ordem. N. 43-44, p. 761-763, set./out. 1933.
} 
Que entenderia por espiritualista o mestre? Não era seguramente a capacidade de crer em Deus (...). Talvez tenha vindo sobretudo desse feitio de espírito a sua força de romancista, a arte de decompor em seus elementos a pessoa humana ${ }^{62}$.

Sua participação na Revista do Brasil, de 1938 a 1943, já registra uma maior independência com relação aos preconceitos morais impostos pela Igreja, porém ainda não apresenta a maturidade intelectual encontrada em Prosa de ficção, em 1950. Durante o período da Revista do Brasil, ela sofre influências de intelectuais progressistas de sua época. Márcia C. Wanderley, em sua tese Lúcia Miguel Pereira Crítica literária e pensamento católico no Brasil, discorre sobre o assunto e cita um artigo, "Dois romances de João Gaspar Simões", em que evidencia essa mudança da crítica no tocante à religiosidade, ao assinalar que Pereira "[tece] elogios a um subjetivismo crítico do qual se confessa partidária, concluindo que idéias e doutrinas podem se transformar em meros artifícios de manipulação e destruição da vida"63.

Os artigos publicados no Suplemento literário do Correio da Manhã, entre 1944 e 1945, já demonstram uma grande distância em relação aos fundamentos catolicistas, pois passa a ter uma postura mais liberal em defesa dos direitos humanos, contra os regimes totalitários europeus e contra a ditadura de Getúlio Vargas. Neles, percebe-se uma "evolução política em direção a um democracismo social" ${ }^{64}$. No texto supracitado, Wanderley salienta o desapego de Pereira aos preceitos católicos em seus textos ao afirmar que "não mais estarão em pauta os princípios da autoridade da ordem e da hierarquia (como havíamos surpreendido naqueles artigos publicados n’ $\underline{\text { A Ordem)}}$,

\footnotetext{
${ }^{62}$ PEREIRA, Lucia Miguel. Machado de Assis - Estudo crítico e biográfico. Belo Horizonte: Itatiaia; São Paulo: EDUSP, 1988. p. 85.

${ }^{63}$ WANDERLEY, Márcia Cavendish. Lúcia Miguel Pereira- Crítica literária e pensamento católico no Brasil. Tese de Doutorado. Pontifícia Universidade Católica do Rio de Janeiro, Rio de Janeiro, 1987. p. 128.

${ }^{64}$ Ibid., p. 129.
} 
mas o elogio da 'liberdade', 'igualdade' e 'fraternidade', direitos sagrados do homem, corporificados pela Revolução Francesa" ${ }^{\text {"65 }}$.

Em 1950, com a publicação do trabalho de historiografia da literatura, Prosa de ficção, Lucia Miguel Pereira não apresenta suas restrições religiosas e morais que lhe impediam um pleno desenvolvimento de suas habilidades literárias. Embasada em recursos teóricos consistentes e mais familiarizada com a literatura, tinha plena condição de analisar a obra literária tanto do ponto de vista externo, isto é, seu meio, quanto da estrutura interna da obra artística.

\section{Lucia Miguel Pereira e outras literaturas}

O vasto conhecimento literário universal possibilitou a Lucia Miguel Pereira analisar obras de diferentes nacionalidades, desde a russa até a norte-americana. Destacaremos seu apreço pelas literaturas francesa, russa e inglesa.

Com relação à literatura francesa, percebemos um forte enfoque humanitário, no sentido de destacar o legado dessa literatura para um maior aprofundamento sobre as questões existenciais.

A propósito de ilustrar nossa afirmação, escolhemos dois autores cujas obras foram analisadas por Pereira: François Mauriac (1885-1970), romancista, ensaísta, poeta, dramaturgo e jornalista, e André Malraux (1901-1976), escritor, crítico de arte e ativista político.

\footnotetext{
${ }^{65}$ Ibid., p. 130.
} 
No ensaio, "Incomunicabilidade e moral em Mauriac", publicado na Gazeta de notícias, em 1935, Pereira se volta para a obra La fin de la nuit, um livro centrado nas relações humanas, em "acomodar o que há de obscuro, de dissociado, de incompreensível no homem moderno" "66. Ainda ressalta que em seus livros "os conflitos entre o homem e o homem [ocorrem] pela incompreensão, pela impossibilidade de se comunicarem"

De Malraux, Lucia Miguel Pereira analisa o livro Le temps du Mépris, no ensaio de 1934, "A fraternidade na obra de Malraux". Segundo a crítica brasileira, tratase de um livro que "aborda a condição humana, em toda a sua miséria e em toda a sua grandeza" 68 . Ainda destaca a ideia de "fraternidade humana" que perpassa o texto ao comentar sobre o escritor como um "comunista [que] não precisou de uma só expressão grosseira (...) da mais leve dramatização da miséria para ser humaníssimo, para dar uma pungente impressão de verdade e sinceridade" ${ }^{\prime 69}$.

Sobre a literatura russa é visível sua predileção por Dostoievski, objeto de várias referências ao longo de seus ensaios e a quem dedica dois artigos. O primeiro, "A propósito de Dostoievski”, publicado em Boletim de Ariel, em 1933 e, em 1935, na Gazeta de notícias, "Dostoievski e a religiosidade russa". Novamente observamos em suas abordagens analíticas a temática humanística permeada por uma preocupação de cunho social e literário.

No primeiro ensaio, compara o povo russo e o brasileiro em dois aspectos: a importação cultural e a grande extensão territorial. Com relação ao primeiro aspecto, Pereira esclarece que os russos foram levados a reagir contra o ocidente devido ao

\footnotetext{
${ }^{66}$ PEREIRA, Lucia Miguel. A leitora e seus personagens. Rio de Janeiro: Grafia, 2005. p. 118-119.

${ }^{67}$ Ibid., p. 119.

${ }^{68}$ Ibid., p. 139.

${ }^{69}$ Ibid., p. 140.
} 
capitalismo, e no Brasil ocorreu um movimento contrário à cultura estrangeira dominante, na busca de uma afirmação nacionalista. A imensidão dos dois países, segundo a crítica, conduz a um sentimento de angústia nos dois casos. Além disso, salienta a questão dos problemas econômicos que atingiram a ambos, como um ponto ao redor do qual gravitavam as características russas e brasileiras, o que ocasionou um "sentimentalismo vago e a vaga religiosidade dos brasileiros, como já [havia] gerado a profunda religiosidade e o sentimento profundo dos russos"70.

Salienta ainda aspectos literários da obra de Dostoievski que, ao representar "a pessoa humana dissociada, e portanto em toda a sua complexidade e em toda a sua verdade, sem nenhum preconceito, sem outra finalidade além de criar a vida na ficção (...)", é aliada à "literatura em torno dos humilhados, dos párias, e a verdadeira literatura realista (...)"71. Assim, já introduz conceitos fundamentais de sua visão romanesca acerca do equilíbrio entre a representação da personagem "de carne e osso"72 e sua intimidade.

Em "A propósito de Dostoievski”", as observações de Pereira recaem na atualidade da obra literária do autor, pois, segundo a crítica brasileira, "um gênio como o seu, feito da essência mesma da vida, não se pode prender a circunstâncias passageiras" ${ }^{, 73}$. Reconhece em suas obras a perspectiva universalizante de sua literatura:

E é justamente [ a ] concepção apocalíptica (...) das coisas que torna tão humano os seus humanos, os seus personagens. E tão inquietantes. Têm alma, uma alma imortal - e experimentam a volúpia quase macabra de poder perdê-la...(...) É a história da humanidade recôndita, subterrânea, que leva a duvidar e a se debater sem nunca alcançar uma resposta; é a história atormentada da própria mentalidade de hipersensível que lemos nos seus livros ${ }^{74}$.

\footnotetext{
${ }^{70}$ Ibid., p. 127.

${ }^{71}$ Ibid., p. $127-128$.

${ }^{72}$ Ibid., p. 124.

${ }^{73}$ Ibid., p. 201.

${ }^{74}$ Ibid., p. 203.
} 
Observa-se a importância que Dostoievski representa para Lucia Miguel Pereira, na medida em que a obra romanesca do autor expressa o caráter universal das personagens ficcionais e manifesta as aspirações humanísticas, características salientadas por Pereira.

A literatura inglesa foi alvo de muitos ensaios da crítica brasileira. Elaborados na década de 40, apresentam uma variedade temática, pois a crítica brasileira foca sua atenção não só em alguns autores em particular, mas também nos elementos estéticos literários peculiares ao povo inglês.

Dentre os vários textos, publicados no periódico Correio da Manhã, sobressaem os dedicados à escritora Virginia Woolf, uma vez que lhe dedica quatro ensaios, nos quais nos deteremos pormenorizadamente nos capítulos posteriores, por tratar-se do foco de nossa pesquisa feita a partir de um trabalho comparativo com a estética literária de Lucia Miguel Pereira. Neste capítulo, serão tratados três ensaios que visam a proporcionar um maior entendimento do ponto de vista de Pereira sobre as características pertinentes à caracterização do povo inglês em relação à sua literatura.

Em “Ilha ou navio?”, Pereira questiona se a rotina dos ingleses não os teria levado à busca de aventuras e daí travar-se "uma luta entre a imaginação inquietadora e o espírito prático, estabilizador $" 75$. Portanto, estabelece um paralelo entre o inglês que sai de sua terra em busca de aventuras e o escritor que também "viaja" através de sua imaginação para elaborar sua produção literária. Dessa forma, a palavra "navio", no título do ensaio, é utilizada em sentido denotativo e conotativo. Sobre esses aspectos, afirma em uma passagem do texto:

\footnotetext{
${ }^{75}$ PEREIRA, Lucia Miguel. Escritos da maturidade. Rio de Janeiro: Grafia, 2005. p. 163.
} 
Para sair de si, para fugir ao spleen [melancolia], o inglês não precisa ser o globe-trotter que toda a gente tem caricaturado, não precisa armar-se de Kodak e chapéu colonial; basta-lhe sentir a natureza especial de sua terra, sondar a alma de sua gente e realizará a maior das viagens. A viagem que têm feito os grandes poetas, os grandes romancistas $^{76}$.

Após ressaltar esses aspectos, mais uma vez enfatiza a importância do caráter universalizante da literatura, no caso, como ela se manifesta na literatura inglesa, ao afirmar que "tanto mais inglês mais universal porque nessa literatura, mais talvez do que em qualquer outra, a não ser a russa, o que é essencialmente nacional se confunde com o que é essencialmente humano"77.

Em "Humorismo e poesia", trata do humor inglês que, ao ser transplantado para a literatura, adquire uma significação muito apreciada por Lucia Miguel Pereira, por ser a expressão do equilíbrio entre o uso da razão e da sensibilidade, elementos que lhe são caros na fatura do texto romanesco.

A partir da apresentação de uma dificuldade em definir o termo "humor", a crítica brasileira propõe um contraponto entre o humorista e o espiritualista, e esclarece que:

(...) se separam radicalmente o espirituoso e o humorista, aquele julgando por um gesto, este buscando todos os aspectos (...). A atitude do primeiro vem só da inteligência, a do segundo de todo o ser, nas suas mais instintivas reações. $\mathrm{O}$ espirituoso tende a desumanizar-se quando ri, o humorista a humanizar-se $(. . .)^{78}$.

Reportando-se ao fato de o humor poder ser encontrado em outros países, como no Brasil, em Machado de Assis, e na Espanha, em Cervantes, reforça o "fundo

\footnotetext{
${ }^{76}$ Ibid., p. 165.

${ }^{77}$ Ibid., p. 166.

${ }^{78}$ Ibid., p. 167.
} 
humano do humour"79 como sua característica marcante. Não é só no caso da Inglaterra que Pereira defende uma estreita união entre a literatura e seu povo, comprovando que o meio social também é fator preponderante na produção literária ao unir o sentimento humanista, constante em suas observações, com a criticidade oriunda da análise do entorno social, pois "seria uma monstruosidade, uma aberração a literatura que não refletisse o gênio da raça da qual nasceu” ${ }^{\prime 80}$. Essa consideração nos remete à tendência literária em sua época, o regionalismo, de voltar-se para as questões sociais de seu tempo, da qual a autora se diferenciou ao acrescentar a essa abordagem a preocupação humanista na representação das personagens no romance.

No ensaio "Imaginação e realismo", Lucia Miguel Pereira aborda o processo criativo no fazer literário, de modo a utilizar a imaginação como ponto de partida para chegar à representação do real. Ou seja, prega a união da sensibilidade artística à racionalidade que, segundo a crítica brasileira, é o caminho pelo qual deve trilhar a literatura. Pereira vê no povo inglês essas características que "se fundem para produzir essa extrema conquista da inteligência e da sensibilidade que é a obra literária da GrãBretanha. Fusão inesperada, surpreendente, raríssima" ${ }^{\natural 1}$.

Ao discorrer sobre o povo inglês e sua história, a crítica brasileira recorre a uma especificidade de terem sido mercadores na construção do Império Britânico, e a partir daí estabelece um paralelo entre a ousadia de o inglês sair de sua terra natal e a capacidade imaginativa em transcender os limites impostos pela realidade tal e qual se apresenta. Isso a leva a dizer que "no guerreiro, no político ou no poeta, a imaginação é

\footnotetext{
${ }^{79}$ Ibid., p. 168.

${ }^{80}$ Ibid., p. 169.

${ }^{81}$ Ibid., p. 171.
} 
a única força realmente criadora. A imaginação que levou Shakespeare a escrever o Rei Lear, e Churchill a antever, nas trevas de 1940, a luz da vitória"82.

Pereira também se concentra na liberdade do povo inglês e a compara com a liberdade das personagens na obra literária quando comenta que "é fora de dúvida que existem nas outras literaturas muitas (...) personagens livres, mas penso que cabe aos britânicos a prioridade - e a maior intensidade - da revolução contra o herói como rei absoluto" $"$. Acredita ser muito importante a liberdade das personagens, pois isso possibilita que se aproximem da realidade e possam se apresentar "como sucede na vida real" ${ }^{, 84}$. Segundo ela, essa liberdade ainda favorece uma maior verossimilhança pela humanização das personagens, que pode ser associada à "índole inglesa: a dos nãomoralistas, dos não-convencionais, dos que sabem ver e aceitar tudo o que existe [e] produziu os políticos mais sábios e os escritores mais humanos dessa terra de políticos tão sábios e escritores tão humanos." ${ }^{, 85}$

Finalmente, podemos concluir que Lucia Miguel Pereira predispõe-se a aceitar as contribuições de diferentes povos, no sentido de reconhecer que a convivência com "o outro" pode ser de grande valia para o aprimoramento de sua crítica literária. Em particular, identifica-se muito com o povo e a literatura da Inglaterra pelas suas características tanto sociais como literárias.

\footnotetext{
${ }^{82}$ Ibid., p. 172.

${ }^{83}$ Ibid., p. 173.

${ }^{84}$ Ibid., p. 173.

${ }^{85}$ Ibid., p. 173.
} 
CAPÍTULO II - O conceito de temporalidade ficcional em Lucia Miguel Pereira 
Lucia Miguel Pereira, em suas incursões pela literatura inglesa, dedica quatro artigos a Virginia Woolf (1882-1941), publicados no periódico Correio da Manhã, em 1944: "Dualidade de Virginia Woolf”; "Crítica e feminismo"; "O Big Ben e o carrilhão fantasista" e "Assombração". Dentre estes, só não analisaremos aqui "Crítica e feminismo", que será objeto de estudo mais detalhado em outro capítulo.

Em “Dualidade de Virginia Woolf” (21/5), Pereira concentra sua análise na comparação entre as facetas romanesca e ensaística da escritora inglesa; em "O Big Ben e o carrilhão fantasista" (18/06) é comentada a estética do romance virginiano; “Assombração" (16/07) é um ensaio que se volta para a contística de Woolf.

Desse modo, os três ensaios são uma oportunidade de avaliarmos as opiniões de Pereira acerca de seus pressupostos estéticos, por meio da comparação com os de Woolf. Além disso, trata-se de acompanharmos os percursos literários de duas escritoras que se assemelham em suas produções literárias, uma vez que ambas enveredaram pela crítica literária em periódicos, escreveram romances e, no âmbito social, preocuparamse com o papel da mulher em suas respectivas sociedades.

No primeiro ensaio, Lucia Miguel Pereira analisa a produção romanesca da escritora inglesa, utilizando como contraponto a produção ensaística de Woolf. O romance Orlando, de Woolf, de 1928, foi o objeto da análise que revela as preocupações estéticas de Pereira. Com relação ao ensaio, a produção de Virginia Woolf é caracterizada como dual pela crítica brasileira, na medida em que é analítica, racional, e ao mesmo tempo vale-se da linguagem romanesca em muitos momentos dos textos. Diferentemente do ensaio, segundo Pereira, os romances só se compõem por meio de sua linguagem peculiar, a narrativa, não se utilizando de uma linguagem crítica que permita a análise detalhada dos fatos cotidianos e sociais. 
O ensaio, por definição, é uma prosa discursiva que expressa uma ideia ou julgamento, que tem como característica um tom informal, de diálogo com o leitor, o que explica sua denominação a partir do termo francês "essai", ou seja, "tentativa", cujo objetivo é a formulação de um texto a partir de um projeto de erros e acertos sobre um determinado tema. Porém, em seu início, tanto na França com Montaigne quanto na Inglaterra com Francis Bacon (1561-1626), a linguagem corrente ainda se reportava à formalidade e ao academicismo. Nesse sentido, a linguagem romanesca, fluida, utilizada por Woolf, aparece como um diferencial, ao conservar a informalidade no tom de conversa com um interlocutor, o que a diferencia de seus compatriotas dos séculos que a precederam. Embora os objetivos do ensaio virginiano estejam de acordo com a definição histórica de ensaio, o texto de Woolf traz inovações na articulação de linguagens, na estrutura e na imbricação do gênero narrativo e ensaístico.

No prefácio da coletânea Ensaístas ingleses, Lucia Miguel Pereira diz que o ensaio tornou-se uma forma tipicamente inglesa e encontrou na Inglaterra sua "pátria de adoção", pois o estilo dos ensaístas ingleses reflete o modus vivendi de seu povo, uma vez que, segundo ela, o gosto pela aventura que caracteriza o modo pelo qual o inglês se relaciona com a vida é o mesmo que aparece na fatura do ensaio: o prazer pelas descobertas, pelas investigações acerca do desconhecido ou do enigmático se manifesta não só em suas viagens, como também em seus textos. Por conseguinte, apesar de reconhecer que o ensaio começa com Montaigne, ela atribui uma grande ligação entre este gênero e os ingleses.

Este posicionamento de Pereira tem de ser apreciado a partir de certos pressupostos que possui acerca da literatura inglesa como um todo. Os ingleses

\footnotetext{
${ }^{1}$ VV. AA. Ensaístas ingleses. Vol. XXVII. Prefácio de Lúcia Miguel Pereira. Tradução de J. Sarmento de Beires e Jorge Costa Neves. São Paulo: Jackson Inc. Editores, 1950. p. V.
} 
venceram o isolamento insular e partiram para novas terras, não levando apenas suas mercadorias, mas também sua vasta literatura por meio de escritores do calibre de Shakespeare, Dickens e Thomas Hardy, entre outros. O ensaio seria, em comparação às viagens, uma prática de aventuras prazerosas, investigações sobre o novo, uma viagem de descobertas e buscas de novas possibilidades. Portanto, a literatura inglesa viaja pelo mundo com a mesma força e intensidade que caracterizam o espírito empreendedor e aventureiro do inglês.

A crítica brasileira ainda aponta dois elementos que lhe são caros na criação literária inglesa de modo geral (e isto inclui o ensaio): a emoção como fator primordial da criação artística aliada à boa elaboração formal do texto, ou seja, emoção estética e técnica de construção textual.

Com relação aos romances de Woolf, Pereira afirma que são "introspectivos [pois neles], não se passa nada", em contraponto aos "sérios ensaios no Times"2. A escritora inglesa é caracterizada como apenas "lírica e fluida" na produção romanesca, ao passo que na elaboração dos ensaios, além de "lírica e fluida", também é "incisiva e lógica". Devemos esclarecer que pelos termos "sensibilidade" e "racionalidade", "emoção" e "razão", "lírica e fluida" e "incisiva e lógica", Pereira se reporta à linguagem ensaística (analítica) e narrativa (artística). É a confluência entre essas duas linguagens que resulta na qualidade do ensaio de Woolf, segundo a crítica brasileira. Por outro lado, a ausência dessa interação, de acordo com ela, deixa o texto romanesco virginiano, com exceção de To the lighthouse, de 1927, não tão bem elaborado.

\footnotetext{
${ }^{2}$ PEREIRA, Lucia Miguel. Escritos da maturidade. Introdução, seleção e notas: Luciana Viégas Rio de Janeiro: Graphia, 2005. p. 107.

${ }^{3}$ Ibid., p. 106.
} 
O ensaio de Virginia Woolf apresenta-se muito mais completo em sua fatura do que o romance porque traz em sua concepção a confluência de gêneros que se traduz na união entre a narratividade própria do romance e a criticidade típica do ensaio. Esta coexistência de ambos os estilos no ensaio articula um aspecto dual que forma uma unidade em tensão dialética. Se no ensaio essa dualidade se transforma em unidade para a boa produção textual, a presença dos aspectos duais no romance existe apenas na escritora como pessoa e não como uma técnica para a formação do texto, uma vez que Lucia Miguel Pereira considera a obra romanesca de Virginia Woolf como um efeito de seus problemas pessoais e psíquicos. Portanto, se no ensaio os contrários se unem para a perfeição da obra, no romance há apenas uma relação de causa e efeito que se reflete no texto como uma forma de "confissão intelectual"4 da autora.

A relação dual entre a linguagem romanesca e analítica observada em Woolf fica patente, por exemplo, nos ensaios reunidos pela própria escritora inglesa em The common reader, de 1925, nos quais predomina um tom narrativo. A junção da técnica de narrar com a vivacidade lógica da crítica propicia prazer ao leitor ao quebrar seu horizonte de expectativa, pois ele lê um texto de crítica literária com o mesmo prazer sentido ao ler um romance. Essa mistura de gêneros tem a capacidade de surpreender o leitor da crítica levando-o a certa fruição estética quando se depara com o inesperado. Dessa forma, este leitor pode sentir-se motivado a ler um livro que está sendo analisado, pois foi atraído pela espontaneidade da linguagem utilizada na nova estrutura textual da análise crítica.

A passagem abaixo, extraída de The common reader, ilustra a utilização da linguagem romanesca na composição do texto ensaístico. Ao lermos o fragmento, observamos a força da narratividade e podemos supor que faça parte de uma ficção. No

\footnotetext{
${ }^{4}$ Ibid., p. 107.
} 
entanto, trata-se de um fragmento extraído de uma obra de crítica literária, na qual

Woolf discorre acerca da personalidade e das características dos ensaios de Montaigne:

Once at Bar-Le-Duc Montaigne saw a portrait which René, King of Sicily, had painted of himself, and asked, "Why is it not, in like manner, lawful for every one to draw himself with a pen, as he did with a crayon?' Off-hand one might reply, Not only is it lawful, but nothing could be easier. Other people may evade us, but our own features are almost too familiar. Let us begin. And then, when we attempt the task, the pen falls from our fingers; it is a matter of profound, mysterious, and overwhelming difficulty ${ }^{5}$.

Ao valer-se da narrativa romanesca para criar seus ensaios, Woolf concretiza a união entre a ensaísta e a romancista, de modo que pode-se, então, falar em uma ensaísta-romancista, o que reafirma a interação dialética na qual ficam evidentes a pulsão dos sentimentos que a arte provoca e a análise crítica sustentada pela inteligência.

A opinião de Pereira sobre o romance de Woolf pode ser explicada ao nos reportarmos às ideias que embasavam a concepção da crítica brasileira sobre o romance: tempo, personagem e recriação da realidade cotidiana. $\mathrm{Na}$ verdade, o aspecto mais importante observado por ela refere-se à recriação da realidade no plano ficcional, o que vai englobar a construção do tempo e da personagem. A linguagem utilizada para essa recriação deve ser, de acordo com Pereira, clara, concisa e objetiva, sem excessos psicologizantes.

\footnotetext{
${ }^{5}$ WOOLF, Virginia. The common reader: First series. New York: HarcourtBooks, 1984. "Certa vez, em Bar-le-duc, Montaigne viu um retrato que Renato, Rei da Sić́lia, fizera de si mesmo, e indagou, 'Por que, da mesma maneira, não é permitido a qualquer um se desenhar com uma pena, como ele fez com crayon? Imediatamente alguém deve ter respondido, que não só é permitido como nada pode ser mais fácil. Outras pessoas podem iludir-nos, mas nossas próprias feições são demasiado familiares. Comecemos. E então, quando nos aventuramos na tarefa, a pena escorrega de nossos dedos; é um assunto de profunda, misteriosa e esmagadora dificuldade." WOOLF, Virginia. O leitor comum. Tradução Luciana Viégas. Rio de Janeiro: Graphia, 2007. p. 23.
} 
Nos romances de Woolf há um alto grau de intimismo psicológico que rompe com a clareza da objetividade, tornando o texto marcadamente lírico, pessoal, sem uma ligação estrita com a realidade. Diferentemente dos ensaios que congregam a razão e a ficção pela linguagem, os romances são muito introspectivos.

Este processo rígido da recriação da realidade por meio do equilíbrio das linguagens defendido por Lucia Miguel Pereira tem muito a ver com a época em que ela viveu e elaborou sua produção literária: o decênio de 30 e o romance regionalista brasileiro. Portanto, faz-se mister nos reportarmos a esse período da literatura brasileira, a fim de delinearmos suas principais características, seus autores e como a crítica brasileira analisou e inseriu-se neste contexto para avaliarmos sua posição em relação à produção romanesca de Virginia Woolf.

A formação da literatura dessa época teve uma contribuição significativa do Modernismo, pois seus pressupostos estéticos e ideológicos seriam os alicerces das manifestações a favor de uma maior liberdade no plano formal e de conteúdo, ao voltarse para as questões nacionais, como evidencia Antonio Candido em Literatura $e$ sociedade:

Parece que o Modernismo (...) corresponde à tendência mais autêntica da arte e do pensamento brasileiro. Nele, e sobretudo na culminância em que todos os seus frutos amadureceram (1930-40), fundiram-se a libertação do academicismo, dos recalques históricos, do oficialismo literário; as tendências de educação política e reforma social; o ardor de conhecer o país ${ }^{6}$.

Portanto, a semana de 22 já prenunciava uma mudança na abordagem literária que se realizaria logo após.

\footnotetext{
${ }^{6}$ CANDIDO, Antonio. Literatura e sociedade. São Paulo: Companhia Editora Nacional, 1980. p. 124.
} 
A opinião de Pereira sobre o modernismo oscilou entre o questionamento e a aceitação da relevância do caráter construtivo do movimento para o romance de 30 . No livro de Luís Bueno, Uma história do romance de 30, em uma entrevista a Homero Senna diz:

A parte destrutiva do movimento foi excelente. Não sei se a parte construtiva também o terá sido, mas é inegável que se fazia necessária uma reação contra aquele academicismo, aquele marasmo, aquele cansaço em que se atolara a literatura nacional ${ }^{7}$.

Em um artigo, "Tendências e repercussões literárias do Modernismo", ao

referir-se à contribuição do Modernismo para o romance de 30, ela escreve:

(...) sem a revolução paulista, esse grupo, composto em boa parte de nortistas, não teria encontrado tão franca e fácil acolhida. (...) Não nos esqueçamos de que o cunho experimental, de busca da realidade próxima, de valorização do homem comum, do negro, do caboclo, assim como o emprego da linguagem coloquial - tudo isso já estava traçado, indicado esquematicamente, à espera de que, sem o embaraço causado nos promotores do movimento de 1922 pela atitude crítica, possuísse a disponibilidade indispensável para fundir todos esses elementos, para fazê-los passar do plano cerebral ao humanamente criador $^{8}$.

Nessa afirmação, Pereira destaca aspectos temáticos e formais do Modernismo que foram precursores do romance de 30. A crítica brasileira ressalta não apenas a contribuição da Semana de 22 no sentido de ruptura com os padrões estabelecidos até então, como também enfatiza sua faceta libertária tanto em termos estéticos, como por exemplo, a utilização da linguagem coloquial, quanto ideológicos, ao propor uma maior identificação com a realidade nacional.

\footnotetext{
${ }^{7}$ BUENO, Luís. Uma história do romance de 30. São Paulo: EDUSP; Campinas: Editora da Unicamp, 2006. p. 63.

${ }^{8}$ Ibid., p. 64.
} 
De fato, o movimento modernista foi o propulsor de sensíveis modificações na estética literária brasileira ao propor uma nova linguagem e temáticas mais voltadas para o Brasil. Isto repercutiu sobre nossa cultura e sociedade, principalmente na literatura e nas artes plásticas.

Porém, outros autores não reconheceram a importância do Modernismo na década de 30, como é o caso de Graciliano Ramos, para quem “os modernistas não construíram: usaram a picareta e espalharam o terror entre os conselheiros"9. Da mesma forma, F.M. Rodrigues Alves Filho, um crítico contemporâneo a Lucia Miguel Pereira, observa no seu livro $O$ sociologismo e a imaginação do romance brasileiro, de 1938:

Acho desde logo, que está bem concretisado (sic) o moderno romance brasileiro. E dizendo MODERNO (sic), não quero filia-lo (sic) ou fixar o limite de seu aparecimento naquela ilusoria (sic) Semana de Arte Moderna, em S. Paulo. De lá veio um ar de excentricidade quasi (sic) ridicula (sic). Não chego ao extremo de afirmar como Otavio de Faria que o "movimento modernista não só não existe, mas de modo algum nunca existiu." (...) O que se pensou fosse de fato a influencia (sic) decisiva, não passou de um erro ou de uma força de expressão ${ }^{10}$.

Vemos, portanto, que houve uma grande controvérsia de opiniões em torno da contribuição do Modernismo para a formação do romance de 30, assim como da importância do movimento em si. De acordo com o crítico, Otávio de Faria nem chegou a considerar sua existência. Ao mesmo tempo, tanto Lucia Miguel Pereira quanto Antonio Candido acreditam na contribuição modernista com relação à reação ao academicismo retórico e exuberante da linguagem que conferiu à geração de 30 a liberdade de uma expressão linguística mais coloquial, uma "libertação operada pelos modernistas"11, na afirmação de Candido. E de acordo com Pereira, "sem prejuízo da

\footnotetext{
${ }^{9}$ Ibid., p. 47.

${ }^{10}$ ALVES, F. M. Rodrigues. O sociologismo e a imaginação no romance brasileiro. Rio de Janeiro: Livraria José Olympio, 1938. p. 9/71.

${ }^{11}$ BUENO, Luís. op. cit, p. 65.
} 
beleza e da emoção artística"12, pois "como sem solução de continuidade, sem mudança do ambiente intelectual, se poderia, de repente, começar a escrever de modo totalmente oposto?"13.

Ao focalizar a realidade do país, a visão do romance adquiriu um caráter mais centrado nos fatos, seja presente na tristeza da seca, dos engenhos, das plantações, seja nos desfavorecidos socialmente, como o pobre e a mulher. Sobre esse assunto, João Luiz Lafetá, em 1930: A crítica e o modernismo, afirma:

A revolução de 30, com a grande abertura que traz, propicia - e pede o debate em torno da história nacional, da situação de vida do povo no campo e na cidade, do drama das secas etc. O real conhecimento do país faz-se sentir como uma necessidade urgente e os artistas são bastante sensibilizados por essa exigência ${ }^{14}$.

No romance de 30 , em que predominou a corrente regionalista, os escritores olhavam com maior atenção as questões sociais em locais específicos, como por exemplo, o Nordeste do país. Já a essência da produção romanesca de Pereira baseou-se no caráter universal da representação da personagem, ou seja, a vertente intimista do movimento. Esse tratamento se diferenciou do padrão regionalista, na medida em que se volta para os conflitos existenciais da natureza humana e às inquietações básicas do ser no confronto com a sociedade, o que caracteriza uma abordagem humanística e social simultaneamente.

O caráter humanístico enfatizado pela crítica brasileira para a consecução de um romance faria com que ela participasse juntamente com outros autores, tais como Lúcio Cardoso, Otávio de Faria, Cornélio Pena, Rachel de Queiroz, entre outros, de uma vertente mais intimista do romance de 30 , que priorizava uma abordagem

\footnotetext{
${ }^{12}$ Ibid. p. 64.

${ }^{13}$ Ibid., p. 64

${ }^{14}$ LAFETÀ, João Luís. 1930: A crítica e o modernismo. São Paulo: Duas Cidades; Ed.34, 2000. p. 32.
} 
abrangente no sentido de explorar a faceta psicológica das personagens inseridas em um contexto social. Dessa forma, Lucia Miguel Pereira desaprova um romance que explore preponderantemente o meio, como podemos observar em suas duras críticas ao movimento naturalista, em Prosa de ficção:

O artista, por mais que se esforce, não se pode conduzir como um homem de ciência. O seu domínio é mais a sensibilidade do que o raciocínio. Mas a moda impunha o exame da criatura humana como se fosse um animal de laboratório ${ }^{15}$.

Ela ainda aponta o caso de Júlio Ribeiro, referindo-se à obra A carne, como um exemplo típico, "que só conseguiu compor um livro ridículo". Ainda sobre esse romance, comenta acerca da personagem Lenita:

Como a maior parte das personagens do nosso naturalismo, foi uma romântica às avessas, isto é, construída, não segundo a observação, mas de acordo com normas preestabelecidas, que prescreviam a substituição dos sentimentos pelos instintos ${ }^{16}$.

Em passagem desse mesmo livro, ao referir-se à obra Canaã, de Graça Aranha,

Pereira esclarece como vê o conceito humanístico no romance:

(...) ao mesmo tempo universal e brasileiro, preso ao seu meio mas apto a desentranhar dele o conteúdo humano, atento à realidade próxima sem por isso abandonar o mundo da poesia e dos conceitos, antes sentindo a interpenetração de todos os planos ${ }^{17}$.

Esse trecho é muito significativo, pois nos remete à estética romanesca de Pereira, na medida em que se reporta ao caráter humanístico, à verossimilhança e à importância que atribui à sensibilidade manifestada na imaginação criadora no momento da elaboração da narrativa.

\footnotetext{
${ }^{15}$ PEREIRA, Lucia Miguel. Prosa de ficção. Belo Horizonte: Itatiaia; São Paulo: EDUSP, 1988. p. 128.

${ }^{16}$ Ibid., p. 131.

${ }^{17}$ Ibid., p. 237.
} 
A importância do caráter humanístico é claramente expressa no ensaio

"Romance de tese e individualidade", publicado na Gazeta de notícias, em 1934:

A pessoa humana, transportada para a literatura, não pode sofrer mutilações, não pode ser afeiçoada por nenhum molde, não pode ser apertada em forma de católico ou de proletário, de burguês ou de espiritualista. Porque antes de ser uma ou outra coisa, é humana. E o romancista, que lida com o material humano e não com idéias, precisa ter o respeito da vida ${ }^{18}$.

Desse modo, a concepção da personagem, de acordo com Lucia Miguel

Pereira, contrasta com a da fase do regionalismo que se volta exclusivamente para os elementos exteriores da realidade:

(...) [o regionalismo] entende o indivíduo apenas como síntese do meio a que pertence, e na medida em que se desintegra da humanidade; visando de preferência ao grupo, busca nas personagens, não o que encerram de pessoal e relativamente livre, mas o que as liga ao seu ambiente, isolando-as assim de todas as criaturas estranhas àquele ${ }^{19}$.

F. M. Rodrigues compartilha com ela essa concepção romanesca que alia aspectos sociológicos ao uso da imaginação criativa no processo ficcional e detecta tal tendência em seu tempo:

Para mim, no romance moderno a imaginação é um ponto de apoio dos escritores, uma fonte subsidiaria (sic) dos romancistas realistas. (...) O romance brasileiro é plural. Cae (sic) mais para a realidade, porque obedece a um logico (sic) "sentido" de ordem nova, que se integra muito mais no campo da observação, objetivo. Mas não fica aí. Só o fato da presença de personagens já indica presença da imaginação porque (...) ou teem (sic) o (sic) seus verdadeiros nome (sic) trocados, ou vieram da ficção (...) ou finalmente são deturpados naturalmente pelo autor que desvia a realidade $(\ldots)^{20}$.

\footnotetext{
${ }^{18}$ PEREIRA. A leitora e seus personagens. Rio de Janeiro: Graphia, 2005. p. 99.

${ }^{19}$ PEREIRA, op. cit., p. 176.

${ }^{20}$ ALVES, F. M. Rodrigues. op. cit. p. 44-45/75.
} 
Reafirmando a posição de Lucia Miguel Pereira, Lúcio Cardoso demonstra preocupação com a ênfase dada ao enfoque voltado para a realidade tal e qual:

(...) só poderei ser conduzido pela imaginação, uma vez que a observação me forneceria apenas os dados da realidade superficial (...) minha concepção de romance vai assim de encontro ao da maioria dos romancistas modernos, que preconisam (sic) uma arte de observação pura, a fotografia da realidade. (...) Não os reconheço como romancistas mas talvez como bons reporteres (sic). Para mim, em cada personagem ha (sic) uma idéa (sic) que se transforma em destino no decorrer do livro. Essa idéa (sic) é que constitue (sic) a verdadeira existência do personagem ${ }^{21}$.

Pereira, no ensaio "A favela verossímil de Lúcio Cardoso”, no qual analisa a obra Salgueiro, ressalta o diferencial do autor em relação aos seus contemporâneos, uma vez que ele não se preocupa em retratar a realidade em si. Suas personagens são concebidas como pessoas que "existem",22, a partir de um trabalho de criação artística: “Salgueiro é um romance real, mas não é um romance realista. (...) Os seus [romances de Lúcio Cardoso] não têm nada de fotográficos. (...) Criação subjetiva, mas execução objetiva.(...) Dentro do ambiente do livro, elas são altamente verossímeis"23.

Pereira e Lúcio Cardoso não concordam com o aspecto documental na prosa regionalista, pois defendem a apresentação de uma realidade na elaboração estética romanesca que se preocupe em mostrar personagens ligadas não só ao seu meio social, mas também que tenham características que se remetam às questões intrínsecas ao ser humano. Mais recentemente, Flora Sussekind, na obra Tal Brasil, qual romance? questiona a recorrência do aspecto naturalista de nossa literatura, em que "à linguagem coubesse o papel de simples 'objetividade', o ser apenas denotação, transparência e

\footnotetext{
${ }^{21}$ Ibid., p. 36-37.

${ }^{22}$ PEREIRA. A leitora e seus personagens. Rio de Janeiro, 2005. p. 124. Em grifo, no original.

${ }^{23}$ Ibid., p. 124.
} 
fissura"24. Ou seja, segundo a autora, a linguagem assumiria um caráter denotativo, sem as características de um texto elaborado literariamente. Nesse sentido, do mesmo modo como ocorreu com o regionalismo, Sussekind destaca a "busca de fidelidade

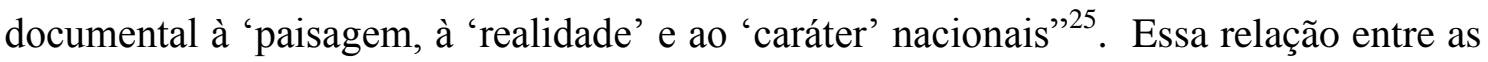
duas autoras é observada por Fernando C. Gil, no ensaio "Contribuições da crítica latino-americana para o estudo do romance rural brasileiro":

Se Lúcia Miguel Pereira observa que há um forte traço documental no romance regionalista que o prejudicaria na configuração de uma produção mais elaborada e de maior alcance estético, já a autora de Tal Brasil, qual romance? sustenta que essa busca por uma espécie de literatura documental pelos nossos escritores é recorrente e obsessiva, e formou o grande sistema estético da prosa ficcional brasileira, que é a estética naturalista ${ }^{26}$.

Dessa forma, a crítica de Lucia Miguel Pereira ao excesso de realismo do regionalismo ecoaria anos mais tarde em Sussekind, como base de uma proposta de leitura da literatura brasileira, a partir da estética naturalista, que, ao esconder o aspecto ficcional, ao optar pelo referencial, estaria ocultando as próprias fraturas de nossa literatura: nosso caráter periférico e o "misto de orfandade e dependência característico de [nossa] literatura" ${ }^{27}$. Desse modo, o que para Pereira revelava um aspecto negativo na representação fotográfica, destituída de uma preocupação universalizante, para Sussekind, trata-se de uma peculiaridade da literatura de nosso país.

A diferença entre a abordagem sociológica e a mais intimista nesse período de nossa literatura é esclarecida por Bueno:

(...) os anos 30 são a época do romance social, de cunho neonaturalista, preocupado em representar, quase sem intermediação,

\footnotetext{
${ }^{24}$ SUSSEKIND, Flora. Tal Brasil, qual romance?. Rio de Janeiro: Achiamé, 1984. p. 35.

${ }^{25}$ Ibid., p. 36.

${ }^{26}$ GIL, Fernando C. "Contribuições da crítica latino-americana para o estudo do romance rural brasileiro”. Disponível em: 〈http:// www.ufjf.br/revistaipotesi>. p. 185. Acesso em: 30 mai. 2011.

${ }^{27}$ Ibid., p. 44.
} 
aspectos da sociedade brasileira na forma de narrativas que beiram a reportagem ou o estudo sociológico. É claro que, nesse tempo, houve também uma outra tendência na qual pouco se fala, uma "segunda via" do romance brasileiro (...) o chamado romance intimista ou psicológico (...) ${ }^{28}$.

Posteriormente, na década de 40, Clarice Lispector priorizou mais as questões existenciais do que observamos em Pereira, de modo que o lirismo predominasse em um texto narrativo, principalmente ao abordar as questões que afligem a alma feminina. Essa concepção textual de caráter filosófico não agradou a alguns críticos, uma vez que o predomínio do tom intimista imprimia um caráter mais subjetivo, o qual contrastava com o tom mais realista da época. Um exemplo dessa atitude é registrado no comentário de Álvaro Lins, crítico contemporâneo a Lucia Miguel Pereira, a respeito do primeiro romance de Lispector, de 1944, Perto do coração selvagem. No ensaio "A experiência incompleta: Clarisse Lispector", da obra Os mortos de sobrecasaca, caracteriza-o como um "romance lírico" 29 , no qual "o que mais se destaca no livro é a personalidade da sua autora"30 e não a obra em si:

Li o romance duas vêzes (sic), e ao terminar só havia uma impressão: a de que êle (sic) não estava realizado, a de que estava incompleta e inacabada a sua estrutura como obra de ficção ${ }^{31}$.

No romance de Pereira, apesar de haver uma marcante preocupação com o ser humano, há também um veio sociológico muito patente. Em sua obra Prosa de ficção, o meio social adquire um importante papel na literatura. Ao analisar a evolução do romance no Brasil, a autora estabelece um paralelo entre sociedade e literatura. A esse respeito, ela afirma que o Brasil foi uma sociedade "que passou do Império tão

\footnotetext{
${ }^{28}$ BUENO, Luís. op. cit., p. 19.

${ }^{29}$ LINS, Álvaro. Os mortos de sobrecasaca. Rio de Janeiro: Civilização Brasileira, 1963. p. 188.

${ }^{30}$ Ibid., p. 189.

${ }^{31}$ Ibid., p. 189.
} 
circunspecto, às agitações da década de vinte, [portanto] não poderiam as obras de ficção deixar de sofrer profundas modificações"32.

Outra preocupação básica na fatura do romance é com as possibilidades de reflexão crítica que o texto propõe. Pereira enfatiza a produção de um texto claro, dotado de objetividade, cuja função precípua seja o uso do intelecto, isto é, um texto marcado pelo aspecto reflexivo. Essa importância reflexiva do texto literário é uma condição que também valoriza para uma crítica literária de qualidade. De fato, seus ensaios são marcados pela objetividade, reflexão e sensibilidade apurada sobre a literatura nacional e universal.

Em vários ensaios sobre diferentes romances nacionais e estrangeiros percebese a concepção romanesca que orienta sua crítica literária ao unir a realidade com a caracterização humana das personagens. Nossa afirmação pode ser comprovada, por exemplo, quando ela se refere ao livro de Graciliano Ramos, Vidas secas, em um ensaio publicado no periódico Boletim de Ariel, em abril de 1938:

(...) o público já está meio cansado de histórias do nordeste, quando se criou essa absurda e ridícula querela literária entre romancistas do norte e romancistas do sul (...). Agora já a moda não é mais favorável aos "documentos humanos", não se usa mais a miséria em literatura. (...) Vidas Secas é um livro de boa humanidade e boa literatura, limpo de intenção e de linguagem. (...) A grande força do autor é a sua capacidade de fazer sentir a vida em potencial, a condição humana intangível e presente na criatura mais embrutecida. (...) um romance onde palpita a vida - a vida que é a mesma em todas as classes e todos os climas ${ }^{33}$.

A partir dessas afirmações de Pereira inferimos que a valorização do elemento social, preocupação básica do romance do Nordeste, deva ligar-se à abordagem humanística, a fim de retratar o ser humano de forma completa, quer seja em seus

\footnotetext{
${ }^{32}$ PEREIRA, Lucia Miguel. Prosa de ficção. Belo Horizonte: Itatiaia; São Paulo: EDUSP, 1988. p. 28.

${ }^{33}$ PEREIRA, Lucia Miguel. A leitora e seus personagens. Rio de Janeiro: Graphia, 2005. p. 150.
} 
aspectos sociológicos, quer seja em relação aos humanos e psicológicos. Lucia Miguel Pereira defende a utilização de uma linguagem clara, objetiva e sem rebuscamento. Ainda, para ela, é fundamental que o romance seja livre de intenções que possam manipular o leitor.

Neste sentido é significativa a polêmica sobre o romance Cacau, de Jorge Amado, uma vez que Lucia Miguel Pereira o criticou asperamente no ensaio "Romance de tese e individualidade", publicado na Gazeta de notícias, em 1934, pelo caráter doutrinário da obra:

Os seus [de Jorge Amado] (...) livros de propaganda (...) é que se destinam aos "leitores gordos e ricos", não para diverti-los, mas para os convencer. Para os seus correligionários é que não haveria de escrever romances intencionais; não se prega a convertidos (...) não posso admitir que a literatura proletária seja exposição de grosserias. (...) Ninguém espera, nem pode esperar, de um operário requintes de linguagem e elegância de maneiras; ele não se exprime só por palavras, não é um indivíduo completamente descontrolado. (...) Há nele [o trabalhador] um fundo de doçura, uma necessidade ingênua de beleza, de ideal, quase de pureza (...) ${ }^{34}$.

Tal controvérsia que posteriormente foi rebatida por Jorge Amado também nos remete à importância dada por Pereira a uma linguagem que expresse o equilíbrio entre a complexidade humana e a representação da realidade tal e qual, o que, segundo ela, faltou ao texto do escritor.

Com relação aos romances de Virginia Woolf, com exceção de To the lighthouse, a discordância de Pereira está fundamentada no excesso de subjetivização das personagens com predomínio da apresentação de seus pensamentos fragmentados em prejuízo de uma trama ficcional mais verossímil.

\footnotetext{
${ }^{34}$ Ibid., p. 102.
} 
Dessa forma, essa narrativa preponderantemente introspectiva inserida em um tempo não-linear vai de encontro à proposta estética da crítica brasileira, ao não apresentar um equilíbrio entre a linguagem objetiva e a intimista e uma temporalidade cronológica.

Porém, Pereira reconhece na composição ensaística de Woolf um texto bem elaborado ao contemplar o equilíbrio entre a razão em seu aspecto analítico, e a ficção no uso da narratividade.

Para um melhor entendimento do romance de Woolf visto como uma prosa preponderantemente subjetiva, sem uma linguagem clara, analisaremos o posicionamento de Lucia Miguel Pereira, tendo como horizonte os pressupostos literários vigentes nos contextos sociais das referidas autoras. Mais especificamente, no Brasil, uma sociedade com sérias dificuldades econômicas sob um regime de exceção, e na Inglaterra, o florescimento da atividade industrial seguida de avanços sociais, científicos e tecnológicos.

Woolf vivenciou um momento histórico no qual o desenvolvimento tecnológico devido à Revolução Industrial foi significativo, além de ter tido contato com as teorias científicas do começo do século XX que se fizeram presentes em todas as áreas do conhecimento. Na literatura, a estética sofreu um processo de mudança significativo a partir de uma abordagem mais psicologizante, ao priorizar a individualidade.

Nessas condições, a opinião de Pereira foi de encontro ao posicionamento estético de Virginia Woolf em relação à fatura do romance, uma vez que os elementos fundamentais na composição romanesca, tais como o tempo, as personagens e o enredo são concebidos diferentemente pelas duas autoras. 
No ensaio "O Big Ben e o carrilhão fantasista” de 18 de junho de 1944, Pereira explorou basicamente o tema da produção romanesca de Woolf ao examinar as diferenças formais e temáticas entre Mrs Dalloway, de 1925, e To the lighthouse, de 1927. Analisa a questão do tempo romanesco, a apresentação das personagens e a elaboração do enredo nos dois romances, de forma que, segundo a crítica, o tempo em Mrs Dalloway é fragmentado, descontínuo e as personagens nos são apresentadas pelos seus pensamentos, sem propriamente um desenrolar dos fatos. Já no segundo romance, o tempo aparece de forma mais linear de modo a proporcionar uma sequência de eventos. Nossa proposta de trabalho é apresentar os aspectos dos romances relacionados e verificar como eles aparecem nos textos de Woolf, e, a partir daí, examinar a posição da crítica brasileira.

Começaremos explicitando o conceito de tempo, fundamental à ficção, cuja definição primeira é o relato de ações em um período determinado. A temporalidade está intrinsecamente ligada à experiência humana, ao conceito do "eu": pelos momentos e mudanças temporais é possível sentir-se pertencente a um determinado grupo social. À medida que se procura a interioridade, há um engajamento na busca dos momentos vivenciados no passado, ao aguçar a consciência do envolvimento com o tempo e seu significado na vida humana.

A noção de temporalidade está muito presente na literatura como afirma Thomas Mann em sua obra A montanha mágica, “(...) [a] narração (...) [apresenta-se] como um fluir, como uma sucessão no tempo" ${ }^{35}$. Tal aspecto é relevante na elaboração literária, uma vez que o enfoque temporal fornece a "tessitura" do texto literário como uma força subjacente que o perpassa e possibilita refletir o modo pelo qual a

\footnotetext{
${ }^{35}$ MANN, Thomas, 1925 apud MENDILOW, A. A. O tempo no romance. Porto Alegre: Ed. Globo, 1972. p. 61.
} 
consciência humana materializa o meio circundante em palavras. Essa ideia de tempo pode ser vivenciada de outra forma, pois se considerarmos preponderante seu aspecto lógico e inexorável, nossa percepção se vincula a um tempo em que suas variantes sejam bem demarcadas e pré- estabelecidas, isto é, há o predomínio do tempo linear, cronológico. Mas, se nos ativermos à concepção da temporalidade que privilegia a sucessão dos momentos oriundos diretamente da consciência, há um tempo privado, pessoal, subjetivo, quer dizer, psicológico. Tal diferença é de fundamental importância na abordagem literária, na medida em que, conforme o enfoque, cronológico ou subjetivo, o autor elabora o texto a partir de diferentes parâmetros para expressar sua visão de mundo.

A abordagem cronológica, muito usada ao longo dos tempos, foi se modificando para uma visão mais psicologizante a partir do momento em que o homem começou a questionar sobre si mesmo e acerca de seu lugar no contexto social. Ao apresentarmos a evolução do conceito de tempo através de diferentes épocas da humanidade, chegaremos ao modo como foi pensado por Lucia Miguel Pereira e Virginia Woolf.

Como já afirmamos, segundo o tratamento convencional do tempo, os eventos se encadeiam de forma linear de modo a apresentar o passado, o presente e o futuro, o que estabelece uma ordem cronológica.

Somente no Renascimento, o tempo começou a ocupar um lugar de destaque na literatura, uma vez que passou a ser considerado como uma força causadora de mudança constante na existência. Essa visão deveu-se às mudanças técnicas e científicas que permitiram à mutabilidade tornar-se um tema central na literatura. O soneto XII de Shakespeare (1554-1616) é um bom exemplo dessa influência na literatura da época: 
When I do count the clock that tells the time, And I see the brave day sunk in hideous night; When I behold the violet past prime, And sable curls, all silvered o'er with white; ${ }^{36}$

Observa-se aí a materialização do tempo ao colocar o objeto (relógio) como parâmetro do passar das horas e, ao utilizar uma personificação para designar a passagem do dia para a noite que se confrontam (noite x dia), há ênfase na noção de mutabilidade.

O conceito de tempo, no qual o passado deixa de ser encarado como somente uma sucessão de fatos completos em si que se estende até o presente, só passará por uma mudança a partir do Romantismo, na segunda metade do século XVIII. Nesse movimento artístico, literário e intelectual, o passado sofre uma transformação conceitual, pois ocorre uma valorização do processo histórico que, desse modo, alia a subjetividade aos fatos, na medida em que o "eu" revitaliza o passado, produzindo a emoção. Coloca-se o sujeito como fonte da experiência estética, em uma nítida reação à Revolução Industrial, no fim do século XVII até o começo do XIX, e ao Iluminismo, no século XVIII, contra o predomínio da razão científica da natureza embutida nesses dois momentos. Há uma mudança da visão que agora assume um caráter de valorização do processo histórico.

Como exemplo dessa retomada do passado, podemos citar o romance de Walter Scott (1771-1832), Waverley, de 1814 , que se passa no período de uma rebelião a favor da volta da dinastia dos Stuart, na Inglaterra. Centra-se na figura do jovem soldado inglês, Edward Waverley, enviado para a Escócia em 1745 para lutar nessa

\footnotetext{
36 "Quando a hora dobra em triste e tardo toque/ E em noite horrenda vejo escoar-se o dia,/ Quando vejo esvair-se a violeta, ou que/A prata a preta têmpora assedia". "Shakespeare- complete works. Oxford: Clarendon Press,1994, p.752. Tradução de Ivo Barroso. Disponível em: 〈http://www.lovers-poems.com>. Acesso em: 03 jun. 2011.
} 
causa. Ele salva a vida de um coronel e se casa com Rose, a filha de um amigo de seu tio. Trata-se de um romance elaborado durante a construção da nacionalidade escocesa. Os romances históricos de Scott se destacam pelo resgate da história e da tradição da Escócia.

Dessa maneira, há a motivação da construção de um país pelo ufanismo, pela glória nacional, pela identificação e superposição do "eu- pessoa" ao "eu-pátria", e a importância do herói nesse processo.

Observa-se a importância do tempo na consciência que, ao trazer de volta as recordações do passado, possibilita que o momento presente seja sentido como o resultado de experiências anteriores, presentes na subjetividade. A visão tradicional de um passado estanque e terminado cede lugar a um processo em que as barreiras entre o momento presente e o passado tornam-se tênues, o que já indica o começo de uma mudança na abordagem da construção temporal na narrativa.

Com relação ao tempo psicológico no romance, o autor inglês Laurence Sterne (1713-1768) foi além de sua época em termos do tratamento da temporalidade no romance. Ao preocupar-se com os detalhes na narrativa e por meio do uso de digressões, estendeu o tempo cronológico e, desse modo, demonstrou evidências do uso do tempo psicológico no romance. Um exemplo dessa técnica utilizada por Sterne é a obra Tristram Shandy (1759-1767). Ao relatar sua história, o protagonista recusa-se a seguir a cronologia dos fatos, movendo-se no tempo. Em decorrência disso, os fatos aparentemente desconexos são justapostos, o que permite à associação de ideias advindas da memória adquirir um caráter marcante no texto. Na realidade, ao estruturar a narrativa dessa maneira, Sterne critica a inclinação para associar e interpretar os fatos de acordo com o que se vê apenas seguindo uma ordem pré-estabelecida. Essas 
características de sua obra são significativas, pois rompem com a utilização do tempo cronológico e destacam seu enfoque psicológico, não mais obediente a fatores externos em termos de marcação da realidade. Torna-se precursor de uma nova abordagem temporal que privilegia o sujeito como parâmetro de uma realidade, não mais retratada pelos fatos externos pura e simplesmente, mas intermediada pelas sensações humanas.

A nova visão do tempo em Sterne foi o prenúncio das mudanças do romance moderno, cujas causas remontam ao surgimento de novas teorias na ciência e tecnologia corroboradas pelo desenvolvimento econômico e social decorrente dos avanços oriundos da Revolução Industrial (1760-1900). O tratamento dado por ele ao romance antecipa de certa forma a técnica utilizada por Virginia Woolf em relação ao tempo, que privilegia os pensamentos das personagens e não obedece a uma ordem linear. Em "The sentimental journey", no livro The second common reader, Virginia Woolf elogia a técnica utilizada por Sterne, quando se refere a Tristram Shandy :

No young writer could have dared to take such liberties with grammar and syntax and sense and propriety and the long-standing tradition of how a novel should be written (...) the order of ideas, their suddenness and irrelevancy, is more true to life than to literature (...) No writing seems to flow more exactly into the very folds and creases of the individual mind, to express its changing moods, to answer its lightest whim and impulse, and yet the result is perfectly precise and composed $^{37}$.

O tempo no romance moderno foi a expressão de um mundo após a formulação da teoria da relatividade de Einstein, na qual o tempo não mais pode ser considerado como absoluto, mas sim como relativo. Além disso, o surgimento da psicanálise

\footnotetext{
37 "Nenhum escritor jovem poderia ter ousado tomar tais liberdades com a gramática e a sintaxe e o sentido e a propriedade de uma longa tradição estabelecida de como um romance deveria ser escrito (...) a ordem das ideias, sua imprevisibilidade e irrelevância relaciona-se mais à vida que à literatura (...). Nenhuma composição parece fluir mais exatamente nas dobras e vincos da mente do indivíduo para expressar suas mudanças de humor, para responder a seu mais leve capricho e impulso, e ainda resultar em uma obra perfeitamente precisa". WOOLF, Virginia. The second common reader. New York: Harvest, 19864. p. 78-79. Tradução nossa.
} 
divulgou a teoria do inconsciente e aumentou o conhecimento sobre a possibilidade de incorporar estados passados ao presente. Em acréscimo, é possível considerar a teoria da durée de Bergson, isto é, a duração interior, psicológica, na qual o tempo flui de modo que os momentos se fundam, estabelecendo uma realidade intuitiva em contraponto com a exterior. Essa formulação é uma reação contra o determinismo das teorias evolucionistas da segunda metade do século XIX que se baseavam no tempo exterior, cronológico. E, finalmente, elencamos como causa da compreensão do tempo na sociedade moderna o advento da Primeira Guerra Mundial, que marcaria profundamente a população dos países envolvidos, corroborando a ideia de um mundo em fragmentação.

No começo do século XX, a noção de mundo se transformara de uma visão harmônica na qual a religião, a ciência, a filosofia e a arte se integravam, para um estado de fragmentação, incoerente e instável, em procura frenética de algo que pudesse substituir as certezas de outras épocas. É um século caracterizado pela “obsessão pelo tempo", já que o homem se viu diante de uma transitoriedade, na qual as modificações sociais e tecnológicas foram rápidas e constantes, e a integração social permanentemente ameaçada. Em uma sociedade com forças conflitantes, sem a firmeza das normas sociais do passado, prevalece um eterno fluir, ou seja, a rapidez é tão marcante que o tempo passa imperceptivelmente.

Em Theorists of the modernist novel, Deborah Parsons refere-se a essa nova abordagem dos fatos:

The beginning of the twentieth century witnessed an international revolution in the arts, as a wide range of cultural groups, aesthetic movements and individual writers and artists sought to extend and transform their relationship with and representation of reality. The 
word 'modernism' represents the retrospective fusion of these very diverse aesthetic experiments into the comprehensive style or social and psychological temper of a 'modern' age, typically dated between 1910 and $1930^{38}$.

A estrutura formal do romance mudou sensivelmente em relação a uma visão tradicional, cujo desenrolar da trama obedecia a um ritmo ditado pelas ações cotidianas mais palpáveis para obter o efeito narrativo de movimento, de anterioridade e posterioridade, os quais caracterizariam a sugestão de uma realidade muito próxima daquela externa à ficção.

Diferentemente dessa visão tradicional, a nova perspectiva de realidade que Virginia Woolf vivenciou e recriou em seus romances não tinha uma preocupação fotográfica dos fatos, mas sim a busca de uma vivência interior como resultado dos processos externos da realidade calcados na subjetividade das personagens em uma sociedade marcada por profundas transformações nos campos artístico, científico e social. No ensaio "The narrow bridge of art" do livro Granite and rainbow, explicita sua visão do romance moderno:

It (the novel) will tell us very little about the houses, incomes, occupations of its characters, it will have little kinship with the sociological novel or the novel of environment (...) it will express the feelings and ideas of the characters closely and vividly, but from a different angle...It will give the relations of man to Nature, to fate; his imagination; his dreams. But it will also give the sneer, the contrast, the question, the closeness and complexity of life (...) - the modern mind $^{39}$.

\footnotetext{
38 "O começo do século XX testemunhou uma revolução internacional nas artes, na medida em que um grande número de grupos culturais, movimentos estéticos, escritores e artistas procuraram aumentar e transformar sua relação com e representação da realidade. A palavra 'modernismo' representa a fusão retrospectiva destes diferentes experimentos estéticos no estilo coeso ou na tendência social e psicológica de uma era 'moderna', costumeiramente datada entre 1910 e 1930." PARSONS, Deborah. Theorists of the modernist novel. New York: Routledge, 2007. p. 11. Tradução nossa.

39 "Ele (o romance) nos contará muito pouco sobre as casas, rendimentos, ocupações de suas personagens, ele terá pouca semelhança com o romance sociológico ou o romance sobre o meio (...) expressará os sentimentos e ideias das personagens íntima e intensamente, mas de um ângulo diferente... Ele estabelecerá as relações do homem com a Natureza, com o destino; sua imaginação; seus sonhos. Mas também mostrará o escárnio, o contraste, o questionamento, a proximidade e complexidade da vida (...) -
} 
A concepção de tempo no romance de Virginia Woolf obedece a uma cronologia que não é muito marcada, pois o que mais a preocupa é o fluir da temporalidade nos pensamentos das personagens, presentificando o tempo pela fusão do passado e presente, tal como se apresenta em suas mentes. Como afirma no ensaio "Character in fiction": "The literary convention of time is so artificial - you have to talk about the weather (...) naturally, the (writers) feeble are tempted to outrage, and the strong are led to destroy the very foundations and rules of literary society" 40 .

As formas do tempo e do espaço deixaram de ser absolutas e tornaram-se relativas e subjetivas, uma vez que o primado da consciência se impõe e questiona a linearidade e a cronologia que já não corresponde a uma realidade verdadeira, pois o homem é visto como parte integrante de um tempo ditado pela sucessão de sensações. Há uma apresentação fragmentada da personagem, focada na simultaneidade dos pensamentos, sem uma ordem lógica. O narrador clássico desaparece ou é omitido, o que resulta na abolição da causalidade e na reprodução a mais próxima possível da experiência psíquica, que passa a ser a prioridade da narrativa.

Nessa nova visão temporal, o enredo passa a desempenhar um papel secundário no processo de verossimilhança, ao ser vencido pela importância adquirida pelo tempo no romance. Benedito Nunes, em $O$ tempo e a narrativa, assinala que ocorreu a "tematização propriamente dita do tempo, integrada, como matéria, à forma

\footnotetext{
a mente moderna". WOOLF. Granite and rainbow. New York: Harvest/Harcourt, 1958. p. 18-19-20. Tradução nossa.

40 "a convenção literária do tempo é tão artificial - você tem que falar sobre o tempo (...) naturalmente, os (escritores) fracos são induzidos ao ultraje e os fortes são levados a destruir as próprias bases e regras da sociedade literária”. WOOLF, Virginia. Virginia Woolf-Selected essays. David Bradshaw (Ed.). New York: Oxford University Press, 2008. p. 51. Tradução nossa.
} 
narrativa", ${ }^{41}$ cuja consequência é a "passagem da consciência individual ao posto de centro mimético da narrativa." 42

Anatol Rosenfeld também pontua essa mudança na concepção romanesca em Texto/Contexto I:

Nota-se no romance do nosso século uma modificação análoga à da pintura moderna, modificação que parece ser essencial à estrutura do modernismo. À eliminação do espaço, ou da ilusão do espaço, parece corresponder no romance a da sucessão temporal. A cronologia, a continuidade temporal foram abaladas, "os relógios foram destruídos" ${ }^{\prime 3}$.

Como afirma Robert Humphrey, tal perspectiva resulta em uma representação da "personagem de uma maneira mais correta e mais realista" 44 , que está inserida em um mundo cujos valores e sentimentos se encontram sob permanente transformação e reflexão. Daí decorre a constante sensação de instabilidade que exigiu adequações estéticas na estrutura narrativa moderna, de modo a abarcar a complexidade das situações psicológicas com as quais o homem se deparava. A necessidade de inovação na elaboração ficcional resulta, portanto, da necessidade da ampliação das possibilidades da forma romance devido às alterações da realidade a partir dos primeiros anos do século XX.

Ao utilizar a técnica do fluxo de consciência, Virginia Woolf estabelece um novo paradigma na elaboração romanesca, pois, agora, a opção pela fluência dos pensamentos das personagens, do texto não-linear, dá vazão a esse novo conceito de uma realidade descontínua ocasionada pelo ritmo frenético imposto pela modernidade.

\footnotetext{
${ }^{41}$ NUNES, Benedito. O tempo na narrativa. São Paulo: Ática, 2000. p. 56. Itálico do autor.

${ }^{42}$ Ibid., p. 56.

${ }^{43}$ ROSENFELD, Anatol. Texto/Contexto I. (Coleção Debates dirigida por J. Guinsburg). São Paulo: Perspectiva, 1996. p. 80.

${ }^{44}$ HUMPHREY, Robert. O fluxo de consciência. Tradução Gert Meyer. São Paulo: McGraw-Hill, 1976. p. 7.
} 
Uma afirmação da escritora no ensaio "Modern Fiction" é altamente esclarecedora em relação à sua opção estética:

Life is not a series of gig lamps symmetrically arranged; life is a luminous halo, a semi-transparent envelope surrounding us from the beginning of consciouness to the end. Is it not the task of the novelist to convey this varying, this unknown and uncircumscribed spirit, whatever aberration or complexity it may display, with as little mixture of the alien and external as possible? We are not pleading merely for courage and sincerity; we are suggesting that the proper stuff of fiction is a little other than custom would have us believe it ${ }^{45}$.

Devemos lembrar que a utilização do fluxo de consciência como forma de representação da realidade não foi exclusividade de Woolf. James Joyce também dele fez uso, notadamente em Ulisses. Essa noção foi elaborada a partir de um estudo descritivo dessa abordagem pelo psicólogo William James, em Princípios de psicologia, de 1890, como comenta Humphrey na obra anteriormente citada : "Na verdade, fluxo de consciência é uma frase para psicólogos. William James a cunhou."46

A opinião de Pereira diferencia-se fundamentalmente em relação à de Woolf, pois essa nova visão do romance moderno tem como parâmetro a realidade vista pelo inconsciente da personagem a partir de uma realidade fragmentada, contrariamente a uma visão não só mais sociológica, como também psicológica sem excessos, de uma corrente do romance de 30. Apesar de a estética de Pereira admitir a abordagem psicológica para uma compreensão da personagem como um todo, a estética de Woolf apresenta-se incompleta, de acordo com a crítica brasileira, ao evidenciar os processos

\footnotetext{
45 "A vida não é uma série de luzes simetricamente colocadas; a vida é um halo luminoso, um envelope semi-transparente que nos cerca do começo até o fim da consciência. Não é a tarefa do romancista expressar este espírito mutável desconhecido e ilimitado, qualquer que seja a aberração ou complexidade que ele possa mostrar, com tão pouco de mistura do alheio e do exterior quanto possível? Não estamos simplesmente suplicando por coragem e sinceridade; estamos sugerindo que o próprio assunto da ficção é um pouco diferente do que o costume nos teria feito acreditar.". WOOLF, Virginia. Virginia WoolfSelected essays. David Bradshaw (Ed.). New York: Oxford University Press, 2008. p. 9. Tradução nossa.

${ }^{46}$ HUMPHREY, Robert. op. cit., p. 1.
} 
do inconsciente e não a apresentação da personagem "em carne e osso" "47. Segundo Pereira, a ação e o enredo em Woolf ficam em um segundo plano, pois “os fatos são em regra de pouca importância, e nem sempre em relação clara com os sentimentos e a evolução das personagens" $" 48$.

O primeiro romance analisado por Pereira é Orlando, uma obra na qual Woolf parodia o texto biográfico. Seu enredo parte do século XVI, no reinado de Elizabeth I, quando Orlando é um belo rapaz de dezesseis anos. Como aprecia muito literatura, envolve-se na elaboração de um poema e se relaciona com os escritores de seu tempo. Mais tarde, ao ser designado embaixador em Constantinopla vive um caso amoroso com uma dançarina e, espantosamente, após ter dormido por uma semana, acorda como mulher. Ao voltar a Londres, sente-se pressionado pelo espírito da era vitoriana, uma época de rigidez de costumes e intensa moralidade, sobretudo em relação ao controle e proibições da participação feminina na vida social. Por fim, casa-se com um marinheiro chamado Shelmerdine. No século XX, ainda como mulher, após perceber as profundas mudanças sociais e tecnológicas desse novo tempo, encontra-se deslocado diante de uma realidade tão diferente das outras que vivenciara.

A obra tem por objetivo satirizar as biografias convencionais, uma vez que as situações e o tempo são irreais. Um ano antes da fatura da obra, Woolf escreveu um ensaio no jornal New York Herald Tribune, em que argumenta a favor de um novo tipo de biografia na qual os fatos sejam imiscuídos na ficção, a fim de mostrar a dicotomia entre a biografia factual e a vida verdadeira:

\footnotetext{
${ }^{47}$ PEREIRA. A leitora e seus personagens. Rio de Janeiro: Graphia, 2005. p. 124.

${ }^{48}$ PEREIRA. Escritos da maturidade. Rio de Janeiro: Graphia, 2005. p. 117.
} 
On the one hand there is truth; on the other there is personality. And if we think of truth as something of granite-like solidity and of personality as something of rainbow- like intangibility and reflect that the aim of biography is to weld these two into one seamless whole, we shall admit that the problem is a stiff one and that we need not wonder if biographers have for the most part failed to solve it ${ }^{49}$.

Em Orlando, é claro o questionamento do trabalho do biógrafo como algo exato, completo. Em uma passagem, o narrador indaga o que é a vida e ele mesmo responde que ela não pode ser contida, como faz o biógrafo, "since a biography is considered complete if it merely accounts for six or seven selves, whereas a person may well have as many thousand. " ${ }^{50}$. Neste trecho, também observamos a influência da psicanálise, em que o inconsciente possibilita o aparecimento de "nossos eus". Nesse sentido, no ensaio “O inconsciente freudiano”, Sebastian Gardner afirma:

Freud intuiu a hipótese do inconsciente como mostrando que somos, em algum sentido novo, ou imprevisto e contra-intuitivo "divididos" constitucionalmente, ou tipos não-unitários de existência ("múltiplos eus", como nos havia sido sugerido chamar os produtos da especulação freudiana e similares) ${ }^{51}$.

Outro exemplo da impossibilidade da exatidão de uma biografia está na seguinte passagem do mesmo romance:

The true lenght of a person's life, whatever the Dictionary of National Biography may say, is always a matter of dispute. For it is a difficult

\footnotetext{
49 "De um lado existe a verdade; de outro existe a personalidade. E se concebermos a verdade como algo parecido com a solidez de um granito e a personalidade como algo semelhante à intangibilidade de um arco-íris - e refletirmos que o objetivo da biografia é unir esses dois em um todo por inteiro, nós admitiremos que o problema é difícil e que não precisaremos nos surpreender se a maior parte dos biógrafos não tem conseguido resolvê-lo." WOOLF. Granite and Rainbow. New York: Harvest/ Harcourt, 1958. p. 149. Tradução nossa.

50 "uma vez que já se considera uma biografia completa aquela que simplesmente enumera seis ou sete eus, embora uma pessoa possa ter muitos milhares." WOOLF. Virginia. Orlando. Tradução Cecília Meireles. Rio de Janeiro: Nova Fronteira, 1958. p. 174.

${ }^{51}$ GARDNER, Sebastião. "O inconsciente freudiano". Disponível em: $<$ http://www.cfh.ufsc.br $>$. Acesso em: 12 out. 2011.
} 
business - this time - keeping; nothing more quickly disorders it than contact with any of the arts ${ }^{52}$.

Nesta profusão de "eus", a temporalidade, elemento de fundamental importância na obra, faz a vida para Orlando parecer eterna. Daí, inferimos a relevância atribuída ao tempo por Woolf. Segundo a autora de Orlando, o tempo apresenta-se fragmentado, sem começo nem fim e sempre presentificado nos momentos que se eternizam pela existência. Na obra Moments of being, a escritora, ao recordar sua infância, pontua: "Those moments - in the nursery, on the road to the beach - can still be more real than the present time." 53

Ao associar o tempo histórico bem demarcado com o tempo fantástico da vida de Orlando, Woolf propõe que as definições dos períodos da história possam ser arbitrárias, uma vez que esse paralelismo entre a "multiplicidade na unidade" do protagonista e as diferentes épocas que vivenciou propicia uma averiguação sobre a própria compreensão tradicional de história, constituída de momentos estanques entre si. Além disso, permite refletir sobre a discrepância entre o tempo interior, vivenciado, e o cronológico, imposto culturalmente.

Outro questionamento proposto por Woolf refere-se à mudança de sexo da protagonista, na medida em que, depois de ela ocorrer, a autora observa "in every other respect, [she] remained precisely as she had been ${ }^{, 54}$, referindo-se aos papéis sexuais definidos que podem ser intercambiáveis: "Different though the sexes are, they

\footnotetext{
52 "A verdadeira extensão da vida de uma pessoa, diga o que disser o Dictionary of National Biography, é sempre matéria discutível. Porque é difícil esse registro do tempo; nada o desordena mais rapidamente que o contato com qualquer das artes”. WOOLF, op. cit., p. 172.

53 "Aqueles momentos na enfermaria, no caminho para a praia - podem ainda ser mais verdadeiros que o tempo presente". WOOLF, Virginia. Moments of being. London: Triad/Grafton, 1986. p. 77. Tradução nossa.

54 “Mas, em tudo o mais, continuava precisamente o que tinha sido". WOOLF, Virginia. Tradução Cecília Meireles. Orlando. Rio de Janeiro: Nova Fronteira, 1978. p. 77.
} 
intermix $"$ "55 . Ao propor a não-diferenciação entre os sexos, reporta-se a um aspecto que considera essencial para a concepção artística: a mente andrógina. A união entre elementos masculinos e femininos, além de denunciar a inferioridade feminina em relação ao masculino em seu tempo, segundo ela, propicia uma condição favorável para a elaboração de uma obra de arte. Essa temática será mais explorada posteriormente ao analisarmos o ensaio de Pereira, "Crítica e feminismo", uma vez que propõe tal discussão.

Em "Dualidade de Virginia Woolf”, a crítica brasileira também se reporta ao mesmo assunto, quando diz que "Orlando é afinal uma tentativa de libertação do sexo e do tempo (...) inquieta [Woolf] por se sentir, intelectualmente andrógina, fadada a pensar ora como homem, ora como mulher" ${ }^{\text {"56 }}$. Pereira explicita em seu texto a atenção de Woolf à questão de gênero, atenção essa com a qual também compartilhava, na medida em que, a exemplo da escritora inglesa, preocupou-se em denunciar a situação social da mulher em seus romances e em alguns de seus ensaios.

Portanto, no contraponto entre o ensaio e o romance virginianos, Lucia Miguel Pereira enfatiza seu posicionamento a favor do ensaio, uma vez que este apresenta uma linguagem equilibrada entre a criticidade e a narratividade. Essa opinião também se coaduna com sua estética literária romanesca, que vê o romance como a síntese dessas linguagens, aliada a uma representação das personagens não só como participantes de um meio social específico, mas representantes dos questionamentos pertinentes a todos os seres humanos.

Em Orlando, a técnica de presentificação do passado não se apresenta tão intensificada como em outros romances, como, por exemplo, Mrs Dalloway (1925) e

\footnotetext{
55 “Embora diferentes, os sexos se confundem". Ibid., p. 105.

${ }^{56}$ PEREIRA, Lucia Miguel. Escritos da maturidade. Rio de Janeiro: Graphia, 2005. p. 108.
} 
The waves (1931), pois as lembranças do protagonista são veiculadas dentro de uma determinada época, ou seja, elas podem ser delimitadas. Já em Mrs Dalloway, apesar de decorrer em um dia, o excesso de apresentação dos pensamentos das personagens não permite que o tempo não fique bem delineado no transcorrer do romance. The waves é calcado basicamente nas rememorações e reflexões das personagens, o que produz uma fluidez temporal preponderante na narrativa e em maior grau que em Mrs Dalloway.

Aliás, o fato de Orlando se estender ao longo de períodos da história da Inglaterra e da literatura inglesa permite a Lucia Miguel Pereira não desconsiderar totalmente sua estética relativamente à construção temporal. Apesar de o tempo do romance ser fantástico, pois seu enredo se passa em trezentos anos, apresenta linearidade temporal no sentido de retratar a sucessão dos fatos históricos e literários. Em "Dualidade de Virginia Woolf", Pereira afirma que, antes de Orlando, Woolf escrevera "uma boa meia dúzia de romances introspectivos, onde não se passava nada",57.

Mrs Dalloway relata um dia na vida de Clarissa Dalloway desde a parte da manhã até a noite. Ela é uma dona de casa da classe alta londrina que prepara uma festa para a noite. Um antigo namorado, Peter Walsh, a visita nesse mesmo dia. O reencontro a faz pensar sobre seu passado e as escolhas que fizera. Ela é casada com um político, Richard Dalloway, com quem tem uma filha, Elizabeth. Paralelamente, é apresentado Septimus Warren, um ex-combatente de guerra obcecado com as lembranças de Evans, um amigo morto em conflito. Ele tem delírios sobre forças ocultas que lhe estão enviando mensagens, o que leva sua esposa, Lucrezia, a procurar assistência médica a fim de cuidar dele. Porém, ao sentir-se sem alternativa para resolver seu trauma, decide suicidar-se.

${ }^{57}$ Ibid., p. 107. 
A festa de Clarissa é um sucesso, e conta até com a presença do Primeiro Ministro inglês. Em uma conversa durante a festa, ela fica sabendo do suicídio de Septimus, e, embora nunca o tivesse encontrado, a notícia a comove a ponto de questionar a alegria que estava vivenciando diante da dor da morte.

Trata-se de um romance voltado tanto aos questionamentos psicológicos quanto aos relacionados ao mundo exterior, o que gera a impressão de que o enredo parece não existir devido à fragmentação temporal, em função de uma preponderância das memórias, arrependimentos e esperanças que pontuam as vidas das personagens. $\mathrm{O}$ tempo assume um tratamento radicalmente intensificado em sua relativização, uma vez que através dele os pensamentos das personagens são expressos pela técnica do fluxo de consciência. Além disso, o fato de o título original do romance ser The hours acentua a preponderância do enfoque temporal que perpassa a obra.

Com relação à construção do tempo no romance, a presença do Big Ben é ambivalente, uma vez que ele atua como relógio, no sentido exato do termo, cuja função é mostrar a passagem do tempo e também criar uma ligação entre as personagens em diferentes lugares, além de permitir que os diferentes fluxos de consciência se unam:

The sound of Big Ben striking the half-hour struck out between them [Clarissa and Peter] with extraordinary vigour, as if a young man, strong, indifferent, inconsiderate, were swinging dumb-bells this way and that (...) speaking to himself rhythmically, in time with the flow of the sound of Big Ben striking the half-hour. (The leaden circles dissolved in the air.) (...) Clarissa's parties. Why does she give these parties? (...) ${ }^{58}$.

\footnotetext{
58 "A batida do Big Ben, marcando a meia hora, ressoou entre ambos [Clarissa e Peter] com extraordinário vigor, como se um homem jovem, forte, indiferente, descuidoso, estivesse a agitar a corda, de um lado para o outro. (...) falando a si mesmo (Peter) ritmicamente, ao compasso daquela vaga sonora, o som direto do Big Ben batendo a meia-hora. (Os pesados círculos dissolviam-se no ar. ) (...) as festas de Clarissa. Por que dá essas festas?" WOOLF, Virginia. Mrs.Dalloway. Tradução Mário Quintana. Rio de Janeiro: Nova Fronteira, 1980. p. 49-50.
} 
E ainda, na reflexão de Clarissa Dalloway: "The sound of the bell flooded the room with its melancholy wave (...) Who at this hour? Three, good Heavens! Three already !"59.

Sobre a técnica de narrar de Woolf, o fluxo dos pensamentos permite penetrar na intimidade das personagens e às vezes indica certa ambiguidade, o que acaba por confundir o leitor. Por exemplo, na passagem que se segue, há uma indefinição de sentido acerca da voz do narrador, ou seja, pode tanto referir-se à opinião de Miss Pym, quanto aos pensamentos de Clarissa sobre os sentimentos de Miss Pym em relação a ela:

There were flowers: delphiniums, sweet peas, bunch of lilac; and carnations (...), Ah yes- so she [Clarissa] breathed in the earthy garden sweet smell as she stood talking to Miss Pym who owed her help, and thought her kind, for kind she had been years ago; very kind, but she looked older, this year, turning her head from side to side among the irises and roses and nodding tufts of lilac with her eyes $(\ldots)^{60}$.

O Big Ben é o leitmotiv para Lucia Miguel Pereira desenvolver sua argumentação sobre Mrs Dalloway no ensaio "O Big Ben e o carrilhão fantasista", também publicado no periódico Gazeta da Manhã, em 1944. Ela opõe "o Big Ben, solene, majestoso, sempre certo (...) lembrando aos homens as leis, os deveres, as coisas sérias"61 a um "carrilhão fantasista e atrasado, cujos sons (...) trazem à memória mil

\footnotetext{
59 "E o som do sino inundava a sala com a sua vaga melancolia (...) Quem seria, àquela hora? Três, meu Deus! Já três horas! Pois, com imponente decisão e dignidade, o relógio bateu três horas (...)". Ibid., p.114.

60 "Por toda parte flores: delfinios, ervilhas-de-cheiro, ramos de lilases; e cravos (...) Ah!- ela [Clarissa] aspirava o suave aroma do jardim terrestre, enquanto conversava com Miss Pym, que lhe devia favores e a supunha boa, pois o tinha sido anos antes; muito boa, mas parecia mais velha aquele ano, volteando a cabeça para um e outro lado, entre os íris, as rosas, os balouçantes tufos de lilases, aspirando-lhes de olhos entrecerrados.". Ibid., p. 16.

${ }^{61}$ PEREIRA, Lucia Miguel. Escritos da maturidade. Rio de Janeiro: Grafia, 2005. p. 116.
} 
insignificâncias, pensamentos não formulados, passageiras preocupações, dúvidas, frivolidades, recordações fragmentárias",62.

Ao criar a metáfora do carrilhão fantasista e opô-lo à precisão do Big Ben, a crítica brasileira reporta-se ao tempo fragmentado da maior parte dos romances de Woolf, especialmente em Mrs Dalloway. Pereira assinala que, ao priorizar o excesso de interiorização das personagens, Virginia Woolf indica que "os fatos [são] em regra de pouca importância, e nem sempre em relação clara com os sentimentos e evolução das personagens"

Em Mrs Dalloway, realmente há uma clara preocupação em retratar os pensamentos, sendo que, algumas vezes, até se confundem. Por isso a afirmação de Pereira em relação ao romance:

Cada minuto, assim desligado do que o precedeu e do que lhe sucederá, torna-se destacado, significativo, é aproveitado inteiramente pelas criaturas a quem essa sensação confere a nítida consciência de estarem vivendo. Vêem-se viver, visão a um tempo exaltante e inibitória, que, se infunde uma certeza, conduz por outro lado à autoanálise ${ }^{64}$.

A técnica de Woolf sobre o modo de compor as personagens é esclarecida em seu diário, durante o processo de criação de Mrs Dalloway:

(...) It may be too stiff, too glittering and tinselly. But then I can bring innumerable other characters to her support... It took me a year's groping to discover what I call my tunneling process, by which I tell the past by installments, as I have need of it. This is my prime discovery so far ${ }^{65}$.

\footnotetext{
${ }^{62}$ Ibid., p. 116.

${ }^{63}$ Ibid., p. 117.

${ }^{64}$ Ibid., p. 117.

65 “[...] Pode ser rígido demais, brilhante e vistoso demais. Mas, então eu posso incluir inumeráveis personagens em seu apoio. Demorei um ano procurando descobrir o que chamo de meu processo de túnel, pelo qual conto o passado aos poucos, conforme necessito. Esta é a minha descoberta mais importante até o momento." WOOLF, Leonard. (Ed.). Virginia Woolf - A writer's diary. London: Triad Granada,1983, pp. 66-67. Tradução nossa.
} 
A estética romanesca de Woolf difere da defendida por Pereira, pois as personagens da autora inglesa são representadas com uma ênfase no psicologismo, dando a aparência de o enredo ser muito reduzido e, consequentemente, aumentando a complexidade de compreensão devido à desconexão entre os nós da trama. Por isso, as personagens, segundo a crítica brasileira, não são verossímeis, não são "gente de carne e osso" $"$.66.

Em vários ensaios de Lucia Miguel Pereira sobre o romance, detectamos essa oposição. Em “A alma flamenga de Gastão Cruls”, publicado na Gazeta de Notícias em 1934, Pereira discute a questão da verossimilhança e do enredo:

Uma das grandes vitórias da arte do romance está em deixar que as personagens continuem a viver além dos limites do livro. (...) É uma grande vitória porque representa uma maior aproximação da realidade. $\mathrm{O}$ romance, em geral, traça o desenrolar de uma crise; e as crises, mesmo as mais profundas, as mais sinceras, as mais pungentes, acabam por se esvanecerem ${ }^{67}$.

Em outro ensaio sobre São Bernardo, ela comenta a apresentação das personagens de Graciliano Ramos:

Que figura bem construída, bem lançada, cruelmente verídica e muito humana (...) esse Paulo Honório, com as suas mãos enormes, calosas, a sua face vultuosa, a sua maldade indiferente, a sua profunda incompreensão de tudo o que não fosse um negócio e, sob tudo isso, um ou outro movimento bom. (...) E não só ele, mas todas as personagens vivem (...) tudo gente de verdade ${ }^{68}$.

\footnotetext{
${ }^{66}$ PEREIRA, Lucia Miguel. A leitora e seus personagens. Rio de Janeiro: Graphia, 2005. p. 124.

${ }^{67}$ Ibid., p. 104.

${ }^{68}$ Ibid., p. 109.
} 
Notamos, nessa descrição de Paulo Honório, não só as características externas, como também as psicológicas, que revelam o caráter universalizante, diferente da ênfase dada ao aspecto individual das personagens por Virginia Woolf.

O modo pelo qual a escritora inglesa constrói suas personagens envolve as preocupações com as questões de cunho existencial, absolutamente intimistas, como memórias, fragmentos de memórias, rememorações e recordações sobre o passado. São vistas por Pereira como "quinquilharias",69, ou seja, detalhes psicológicos nos textos da escritora inglesa que desencadeiam não só o fluxo de consciência, como também a aparente falta de conexão entre os assuntos. Isto tudo, para Lucia Miguel Pereira, compromete a verossimilhança do texto, fragilizando a ligação entre ele e a realidade externa. A passagem abaixo exemplifica o conceito de "quinquilharias".

(...) flores para a festa de Clarissa Dalloway, o bule de chá sempre entupido dos Pagiter, o tricô de Mrs. Ramsay, o quadro inacabado de Lily Bricoe (sic), o guarda sol de Mrs. Flanders, o bote de Jacob (...) isso tudo guardando ecos de risos, de palavras, de emoções (...) numa desordem que não é senão uma ordem desconhecida ${ }^{70}$.

No entanto, Pereira reconhece em Mrs Dalloway qualidades que a fazem afirmar que "cada fragmento tem sentido, e beleza, que de todo esse aglomerado se destaca a figura de Clarissa, uma das boas criações de Virginia Woolf'. Porém, reforça a importância de uma sucessão de fatos em um tempo linear, ao afirmar que “(...) [quando] ela [Woolf] encontra o equilíbrio entre as duas vozes sempre a ressoarem no seu espírito - a do Big Ben e a do carrilhão fantasista - o apelo da unidade e os acentos da diversidade (...) atinge às culminâncias do romance contemporâneo"71. Esse

\footnotetext{
${ }^{69}$ PEREIRA, Lucia Miguel. Escritos da maturidade. Rio de Janeiro: Grafia, 2005. p. 116.

${ }^{70}$ Ibid., p. 116.

${ }^{71}$ Ibid., p. 118.
} 
"acordo"72 entre os dois relógios, ou seja, a equivalência entre o tempo linear e o fragmentário é salientada pela crítica brasileira ao se referir a To the lighthouse .

Com relação a Virginia Woolf, a questão da representação da realidade é questionada em um ensaio central para o entendimento de seus padrões estéticos: "Character in fiction”, de 1924. Em suas reflexões, Woolf pergunta-se: “...I ask to myself, what is reality? And who are the judges of reality?"73. Por meio dessas perguntas, a autora inglesa já se propõe à criação de um novo conceito de construção da realidade em seus romances, ao ter como objetivo retratar a vida, principalmente, através de uma apresentação mais subjetiva das personagens que, segundo ela, é o melhor meio de elas serem mostradas verdadeiramente.

No ensaio "Modern Fiction", o comprometimento do escritor com a realidade é questionado por meio da personagem. Se o conceito de representação da realidade para Virginia Woolf é permeado pela introspecção, outro elemento de análise ganha agora relevância estética como complemento desse movimento de introversão: a personagem em processo de construção, pois é só através dela que o mundo externo adquire uma forma, uma vez que ela atua como elemento de ligação entre o interior e o exterior ao apreender, sentir e expressar as percepções da realidade externa:

The writer seems constrained, not by his own free will but by some powerful and unscrupulous tyrant who has him in thrall, to provide a plot, to provide comedy, tragedy, love interest, and an air of probability embalming the whole so impeccably that if all his figures were to come to life they would find themselves dressed down to the last button of their coats in the fashion of the hour.(...) Is life like this? Must novels be like this? ${ }^{74}$

\footnotetext{
${ }_{72}^{72}$ Ibid., p. 119.

73 "Eu me pergunto, o que é realidade? E quem são os juízes da realidade?" WOOLF, Virginia. Virginia Woolf-Selected essays. David Bradshaw (Ed.). New York: Oxford University Press, 2008. p. 43. Tradução nossa.

74 “O escritor parece coagido, não pelo seu próprio livre-arbítrio, mas por um tirano poderoso e inescrupuloso que o controla, a providenciar um enredo, a providenciar comédia, tragédia, interesse amoroso e um ar de probabilidade embalsamando o todo tão impecavelmente que, se todas as figuras
} 
Para Virginia Woolf, a liberdade com relação à representação da personagem é

tanta que, às vezes, essa mesma personagem chega a se multiplicar e, ao mesmo tempo,

fundir-se com o exterior em busca de uma completude de si mesma:

(...) she [Mrs Dalloway] felt herself everywhere; not 'here, here, here'(...) but everywhere. She waved her hand, going up Shaftesbury Avenue. She was all that. So that to know her, or anyone, one must seek out the people who completed them, even the places" ${ }^{97}$.

No ensaio "Character in Fiction", Woolf comenta:

I believe that all novels (...) deal with character, and that is to express character (...) All human relations have shifted (...) And when human relations change there is at the same time a change in religion, conduct, politics and literature ${ }^{76}$.

A importância da liberdade na criação da personagem é ainda pontuada por Virginia Woolf em outro ensaio, "Mr Bennet and Mrs Brown”, resposta ao crítico Arnold Bennet (1867-1931), vindo de uma geração de intelectuais que a precedeu. A autora não concordava com o excesso de detalhes na caracterização da personagem defendida pelo crítico e considerava crucial sua construção no romance, uma vez que esse tipo de caracterização não criava efeitos de realidade: "Every sort of town is represented, and innumerable institutions [but] (...) in all that congeries of streets and houses, there isn't a

adquirissem vida, elas se descobririam totalmente vestidas na última moda até o último botão de seus casacos (...) A vida é assim? Os romances devem ser assim?”. Ibid., p. 8-9. Tradução nossa.

75 “'(...) se sentia [Mrs Dalloway] em toda parte, não 'aqui, aqui, aqui'(...) mas em toda parte. Estendia a mão, enquanto corriam pela Shaftesbury Avenue. Ela era tudo aquilo. De modo que para conhecê-la ou a qualquer outra pessoa, era só procurar a gente que fosse o seu complemento; a gente, e também os lugares." WOOLF, Virginia. Mrs. Dalloway. Tradução Mário Quintana. Rio de Janeiro: Nova Fronteira, 1980. p. 147.

76 “Acredito que todos os romances (...) lidam com a personagem, e que é para expressar a personagem (...) Todas as relações humanas mudaram (...) E quando as relações humanas mudam, ao mesmo tempo, ocorre uma mudança na religião, na conduta, na política e na literatura. WOOLF, Virginia. Virginia Woolf-Selected essays. David Bradshaw (Ed.). New York: Oxford University Press, 2008. p. 38/42. Tradução nossa. 
single man or woman we know" "77. E criou uma "flesh and blood Mrs Brown" ${ }^{78}$, ou seja, uma personagem real, segundo seu ponto-de-vista.

Observamos, portanto, que tanto Woolf quanto Pereira buscam expressar a realidade por meio da personagem, porém trilhando caminhos opostos. Se para a autora de To the lightouse a realidade é construída pela apresentação dos pensamentos, para a crítica brasileira, é necessário uma personagem não só real em sua caracterização exterior, mas também que apresente uma certa interiorização ao expressar as inquietações humanas.

A técnica utilizada por Virginia Woolf reflete uma mudança de visão de mundo marcada pelos desenvolvimentos que causaram um novo modo de sentir a realidade circundante no começo do século XX. Roger Fry, em 1912, na introdução ao catálogo da segunda mostra de pós-impressionismo, declara em relação aos artistas participantes:

(...) I mean that they wish to make things which by their clearness of their logical structure, and by their close-knit unity of texture, shall appeal to our disinterested and contemplative imagination with something of the same vividness as the things of actual life appeal to our practical activities. In fact, they aim not at illusion, but at reality" ${ }^{39}$.

Essa nova perspectiva de realidade que Virginia Woolf vivenciou e recriou em seus romances não tinha uma preocupação fotográfica dos fatos, mas sim a busca de uma vivência interior como resultado dos processos externos da realidade, calcada na subjetividade das personagens em uma sociedade marcada por profundas transformações nos campos artístico, científico e social, como citamos anteriormente.

\footnotetext{
77 “Todo tipo de cidade é representada, e inumeráveis instituições [mas] (...) em todos aqueles amontoados de ruas e casas, não há um único homem ou mulher que conheçamos”. Ibid., p. 33. Tradução nossa.

78 “Mrs Brown de carne e sangue". Ibid., p. 35. Tradução nossa.

79 “(...) Eu quero dizer que eles desejam fazer coisas que, pela clareza de sua estrutura lógica e pela urdidura, irão atrair nossa imaginação contemplativa e desinteressada, com a mesma nitidez que as coisas da vida real atraem nossas atividades práticas. De fato, o objetivo não é a ilusão, mas a realidade." LEE, Hermione. The novels of Virginia Woolf. London: Metheun \& Co Ltd, 1977. p.16. Tradução nossa.
} 
Foi a partir dessa contingência que o romance começou a contrapor o tempo linear, objetivo, ao tempo vivido segundo uma abordagem introspectiva, fragmentada, como a própria experiência humana em um mundo incompleto, devido às constantes mudanças trazidas pelas inovações tecnológicas em ritmo acelerado.

A narrativa de Proust, que rompe com a técnica de apresentação tradicional da personagem ao utilizar-se da memória como fio condutor do texto, é muito apreciada por Virginia Woolf, e se coaduna com os pressupostos do seu texto. Na realidade, ela deixou bastante clara sua admiração pela literatura proustiana: "Proust so titillates my own desire for expression that I can hardly set out the sentence. Oh! If I could write like that!.." 80 .

Em outro momento, ao envolver-se na escritura de Mrs Dalloway, Woolf afirma:

I wonder if this time I have achieved something?... Well, nothing compared with Proust, in whom I am embedded now. The thing about Proust is his combination of the utmost sensibility with the utmost tenacity. He searches out these butterfly shades to the last grain. He is as tough as catgut and as evanescent as a butterfly's bloom. And he will I suppose both influence me and make me out of temper with every sentence of my own ${ }^{81}$.

É também inegável a motivação que Proust desperta em Virginia Woolf com relação à utilização do fluxo de consciência, como forma de narrar, uma vez que ambos valem-se da apresentação dos processos psíquicos em um movimento contínuo, como em Mrs Dalloway:

\footnotetext{
80 "Proust incita tanto meu próprio desejo de expressão que eu mal posso começar a frase. Oh! Se eu conseguisse escrever daquele modo!..." WOOLF, Virginia apud BOTTON, Alain. How Proust can change your life: Not a novel. New York: Random House/Pantheon, 1997. p. 185-186. Tradução nossa.

81 "Eu me pergunto se dessa vez realizei algo? Bem, nada comparado a Proust, em quem eu estou enterrada agora. Em relação a Proust podemos falar de sua combinação da maior sensibilidade com a maior tenacidade. Ele examina estas sombras de borboleta minuciosamente. Ele é tão duro quanto uma corda e evanescente quanto o nascimento de uma borboleta. E suponho que ele tanto me influenciará quanto me deixará de mau humor com cada frase minha.”. Ibid., p. 186. Tradução nossa.
} 
Well indeed he [Peter Walsh] had got himself into a mess at his age.(...) Suppose they [Peter and Daisy] did marry ? For him it would be all very well,but what about her ? Mrs Burgess (...) thought this absence of his in England, ostensibly to see lawyers, might serve to make Daisy reconsider, think what it meant. It was a question of her position, Mrs Burguess said; the social barrier; giving up her children 82.

Porém, apesar do vanguardismo de Proust em relação à narrativa, há divergência entre sua técnica ficcional e a de Woolf, pois embora aquela utilizada pelo escritor francês tenha um expressivo caráter intimista, recorre a um fato externo no presente a fim de relatar o ocorrido no passado pela rememoração. Já na autora inglesa, observamos o pensamento fluir constantemente numa narrativa, descrito de um modo caótico, sem relação de causa e efeito. A respeito desse diferencial, Anatol Rosenfeld comenta que o romance de Woolf:

(...) vai tecnicamente muito além de Proust. Já não existe um Eu narrador fixo face a um Eu narrado em transformação; o próprio Eu narrador se transforma constantemente, como se a autora quisesse demonstrar a relatividade de tudo e a teoria de Einstein; possivelmente a relatividade da própria teoria da relatividade ${ }^{83}$.

Lucia Miguel Pereira no ensaio “O Big Ben e o carrilhão fantasista” também tece alguns comentários sobre a estética proustiana. Neles, ela o une a Virginia Woolf em termos de "obsessão do tempo" ${ }^{\text {", }}$, e os separa quando afirma que "nele o tempo domina as personagens, nela é por estas dominado" ${ }^{\text {. }}$. Ainda observa outro ponto de divergência entre ambos: "em Proust, uma sensação permite recuperar o tempo perdido;

\footnotetext{
82،"Metera-se [Peter Walsh] realmente em uma embrulhada, na sua idade (...) E supondo que casassem?[Peter e Daisy] Para ele seria excelente. Mas para ela? Mrs. Burgess (...) achava que aquela sua ida à Inglaterra, ostensivamente para consultar advogados, serviria para que Daisy reconsiderasse e pensasse no que ia fazer. Tratava-se da sua posição, dizia Mrs. Burgess, das convenções sociais; do futuro dos seus dois filhos." WOOLF, Virginia. Mrs. Dalloway. Trad. de Mário Quintana. Rio de Janeiro: Nova Fronteira, 1980. p. 151.

${ }^{83}$ ROSENFELD, Anatol. Reflexões sobre o romance moderno. In: Texto/Contexto I. São Paulo: Perspectiva, 1996. p. 93.

${ }_{85}^{84}$ PEREIRA, Lucia Miguel. Escritos da maturidade. Rio de Janeiro: Grafia, 2005. p. 117.

${ }^{85}$ Ibid., p. 117.
} 
em Virginia o tempo não chega a se perder (...)"86 . O tempo, para a escritora inglesa, é expresso pelo pensamento caótico das personagens, o que o torna quase imperceptível em seu fluxo.

Pereira acredita que a técnica utilizada por Proust seja mais relevante com relação à realidade do que a utilizada por Woolf. Ao dominar as personagens, o tempo apresenta-se cronologicamente e divide os fatos em um antes e um depois, criando, dessa maneira, uma ordem compreensível, o que não ocorre na maior parte dos romances virginianos.

A questão da verossimilhança das obras de Woolf também foi abordada na Inglaterra, como afirma a crítica literária contemporânea de Virginia Woolf, Q. D. Leavis, na sua obra Fiction and the reading public, de 1932, na qual revela um panorama da situação da leitura em seu país: “(...) the usual complaints of would-be readers of Mrs. Woolf's novels are 'She doesn't write about anything,' Her characters aren't real,' and 'There isn't any story" ${ }^{\prime 87}$. Embora os romances de Woolf fossem elogiados por parte da crítica, causaram estranhamento aos leitores de sua época. Isto pode ser explicado pela afirmação de Leavis que se tratava de "a public accustomed to nothing more ambitious than the elementary prose of the journalist (...) ${ }^{\text {"88 }}$.

Isto significa que, mesmo no contexto social inglês, os textos de Woolf apresentaram dificuldades para os leitores não acostumados com uma linguagem mais rebuscada e enredos mais psicologizantes. Pereira reconhece a sensibilidade da escritora

\footnotetext{
${ }^{86}$ Ibid., p. 117.

87 “As reclamações usuais dos supostos leitores dos romances da Sra. Woolf são 'Ela não escreve sobre nada, 'Suas personagens não são reais, 'e 'Não existe nenhuma história'”. LEAVIS, Q. D. Fiction and the reading public. London: Chatto \& Windus, 1968. p. 222-223. Tradução nossa.

88 "Um público acostumado a nada mais ambicioso que a prosa elementar do jornalista”. Ibid., p. 222. Tradução nossa.
} 
inglesa, no entanto, não aprecia o excesso verbal e um tom altamente intimista que se oponha a um texto cuja clareza e objetividade sejam comprometidas.

Em “O Big Ben e o carrilhão fantasista", Lucia Miguel Pereira contrapõe Mrs Dalloway a To the lighthouse. Para ela, o segundo romance não apresenta certa “confusão" em relação à trama, como acontece no primeiro, pois nele ocorre uma sucessão de fatos permeados pelos pensamentos das personagens.

O enredo de To the lighhouse é focado no conflito ocasionado pelo desejo de James, o filho mais novo da Sra. Ramsay, de visitar o farol. Porém, seu pai não está disposto a ir. O romance divide-se em três partes: "A janela" descreve um dia nas férias de verão na Escócia, na casa dos Ramsays, que recebem uns convidados, incluindo uma pintora, Lily Briscoe; um poeta, Augustus Carmichael; um cientista, William Bankes; e um acadêmico, Charles Tansley. Na segunda parte, "O tempo passa", a Sra. Ramsay morre e seu filho mais velho, Andrew, é morto na I Guerra Mundial. Sua filha Prue morre durante o parto. Lily Briscoe e Augustus Carmichael voltam à casa abandonada dos Ramsays, e Lily lembra-se dos momentos que passou com eles. Na última parte, "O farol”, Lily pinta um quadro inspirado na Sra. Ramsay e, finalmente, o Sr. Ramsay leva James ao farol.

Aqui, notamos uma estruturação do tempo que se diferencia de Mrs Dalloway, no qual é absolutamente fragmentado. Em To the lighthouse, a sequência temporal é mais perceptível e sustentada pelos fatos que se ordenam cronologicamente, muito embora haja digressões e rememorações. As ações do romance são comentadas por Lucia Miguel Pereira no ensaio "O Big Ben e o carrilhão fantasista”: “(...) a discussão sobre se o tempo permitiria ou não o passeio ao farol, Sra. Ramsay lendo histórias para 
o filho, o retrato feito por Lily Briscoe, o noivado de duas personagens secundárias: fazem pensar em profundezas invisíveis" $"$.

Nesse mesmo ensaio, apesar de detectar alguns pontos negativos no romance ao apontar "um exagero de minúcias, um capricho no acabamento", além de "um requinte verbal", Pereira reconhece "a admirável singeleza, com a economia de linhas dos grandes artistas" ${ }^{90}$, ao referir-se à construção das personagens, principalmente a Sra. Ramsay, que salta aos olhos da crítica brasileira pela sua presença marcante.

$\mathrm{O}$ romance To the lighthouse, como um todo, apresenta uma linguagem comedida, controlada, bem recebida por Lucia Miguel Pereira. Não há um predomínio da técnica de fluxo de consciência e, sim, uma combinação entre o fragmentário e a totalidade, em que a presença de detalhes, segundo seu ponto de vista, não afeta a compreensão do enredo. Dessa forma, Pereira observa no romance um equilíbrio, "um acordo entre o Big Ben e o carrilhão fantasista", o que a leva a considerá-lo como sendo "a maior vitória de Virginia Woolf, como romancista e como artista". Ela afirma que "a vida se une à arte para fixar o momento fugaz" ao referir-se a uma passagem sobre a Sra. Ramsay, na qual a personagem diz: "Aqui a vida fica parada". Nesse aparente paradoxo entre a permanência e a fugacidade, entre o movimento e a imobilidade, a crítica brasileira reconhece na autora inglesa características que, como já apontamos, considera precípuas à elaboração romanesca: a realidade externa aliada a aspectos psicologizantes:

Nesse romance, mais do que em qualquer outro, se percebe o que é o mundo de Virginia Woolf: um mundo espiritualista e artístico,colorido e silencioso (...) onde as almas são quase tão perceptíveis como os corpos (...) Com ela (Sra.Ramsay), o presente resume o passado e

\footnotetext{
${ }^{89}$ PEREIRA, Lucia Miguel. Escritos da maturidade. Rio de Janeiro: Grafia, 2005. p. 118.

${ }^{90}$ Ibid., p. 119 .
} 
antecipa o futuro, não há remorsos nem inquietações, tudo é claro e uno $(\ldots)^{91}$.

Enfim, a visão de Lucia Miguel Pereira acerca do romance em questão evidencia a harmonia entre a abordagem intimista característica de Woolf e a expressão humana das personagens aliada à representação dos fatos cotidianos que movem as vidas das pessoas inseridas em um determinado tempo.

Ao reportar-se sobre o excesso de introspecção presente em boa parte na fatura do romance de Woolf, a crítica brasileira registra: “(...) os sentimentos são como que diluídos pela própria duração, estados mais do que emoções, e por isso mesmo permanentes" ${ }^{92}$. Ela já elabora uma análise que, embora não se refira a To the lighthouse, coincide com a de Auerbach em outro contexto histórico e social acerca desse romance. Em 1946, ou seja, dois anos após a publicação do texto de Pereira, no ensaio "A meia marrom", ele afirma: "O escritor [Virginia Woolf], como narrador de fatos objetivos, desaparece quase que completamente; quase tudo o que é dito aparece como reflexo na consciência das personagens do romance.",93

$\mathrm{O}$ aspecto psicologizante, altamente interiorizado, da produção romanesca de Woolf aparece de forma exacerbada no romance The waves, de 1931, sobre o qual Pereira também afirmou ser um exemplo da obsessão da escritora pelo tempo. Se, em To the lighthouse, a crítica brasileira vê um equilíbrio entre os fragmentos e a totalidade na representação das personagens, assim como no enredo, em The waves vários aspectos diferem radicalmente dessa postura. A própria estrutura do livro já se distancia

\footnotetext{
${ }^{91}$ Ibid., p.119.

92 Ibid., p.119.

93 AUERBACH, Erich. Mimesis. (Coleção Estudos, dirigida por J. Guinsburg). São Paulo: Perspectiva, 2002. p. 481.
} 
consideravelmente dos pressupostos estéticos do romance aceitos pela crítica brasileira, pois é elaborado a partir de monólogos, prescindindo de uma narração corrente, fluida.

Em The waves, o leitor segue a vida de seis pessoas: Bernard, Neville, Louis, Jinny, Susan, Rhoda e um sétimo, Percival, que não aparece como personagem, sendo apenas mencionado. Todos convivem desde a infância até a maturidade, período representado por nove entreatos (intervalos entre dois atos teatrais). A narração é feita através de solilóquios dirigidos ao leitor, sendo de Bernard a maior parte dos monólogos. Apesar de não haver diálogos, as falas podem se referir a um mesmo assunto, pensamento ou a uma mesma situação, como, por exemplo, quando vão à escola pela primeira vez:

'Now, said Bernard, 'the time has come. The day has come. The cab is at the door (...) I'm going to school for the first time.

'Here is Bernard,' said Louis. 'He is composed; he is easy. He swings his bag as he walks. I will follow Bernard, because he is not afraid.'

'This is my first night,'said Susan, 'away from my father, away from my home. My eyes swell; my eyes prick with tears.(...)'.'The purple light', said Rhoda, 'in Miss Lambert's ring passes to and fro across the black stain on the white page of the Prayer Book. ${ }^{94}$

Em seu diário, Woolf explica o processo da elaboração formal do romance como um texto marcado pelo movimento contínuo das ondas: "The Waves is I think resolving itself (I am at page 100) into a series of dramatic soliloquies The thing is to keep them running homogenously in \& out, in the rhythm of the waves. Can they be

\footnotetext{
94 ،“'Agora - disse Bernard - chegou a hora. Estamos no dia aprazado. O táxi está à porta.(...) Vou à escola pela primeira vez./ 'Aqui está o Bernard - disse Louis - tem um ar composto; está à vontade. Abana a mala à medida que caminha. Dado que não tem medo de nada, o melhor que tenho a fazer é segui-lo./Este é o meu primeiro dia na escola - disse Susan -, longe de meu pai, longe de casa. Tenho os olhos inchados; as lágrimas fazem-me arder os olhos (...)/- A luz vermelha - disse Rhoda -, no anel de Miss Lambert move-se de um lado para o outro na mancha negra existente na página branca do livro de Orações." WOOLF, Virginia. As ondas. Tradução Lucília Rodrigues. Lisboa: Publicações EuropaAmérica, 1992. p. 20-22.
} 
read consecutively? I know nothing about that" ${ }^{\text {995 }}$. Uma possível explicação para o uso da metáfora das ondas seria a alusão às oscilações de unidade e separação das personagens, imprimindo um movimento similar ao do mar.

No romance há o predomínio dos pensamentos, reflexões sobre a vida e a morte, a consciência e impressões das existências das personagens, das quais algumas se repetem ao longo do texto: "Life is pleasant. Life is good. The mere process of life is satisfactory" ${ }^{\prime 96}$. O tempo se apresenta como momentos que fluem, sem um antes nem um depois, só o presente, os momentos que se eternizam pela existência, aos quais já nos referimos:

'Yes, but suddenly one hears a clock tick. We who had been immersed in this world became aware of another. It is painful. It was Neville who changed our time. He, who had been thinking with the unlimited time of the mind, which stretches in a flash from Shakespeare to ourselves $(\ldots)^{97}$.

A leitura do texto é complexa devido aos cortes na narrativa e à mudança das falas das personagens, o que colabora para um texto com caráter preponderantemente subjetivo. Esse é um dos aspectos que gerou a controvérsia literária entre os críticos no ano de sua publicação. Harold Nicolson, em um ensaio, afirma sua admiração pelo texto: "Her [Virginia Woolf] whole intention is to depict the fluidity of human experience (...). Her book sparkles with a thousand diamonds, and at times it is

\footnotetext{
95 “As Ondas acho que está se resolvendo por si mesmo (estou na página 100) em uma série de solilóquios dramáticos. O jeito é deixá-los caminhar homogeneamente por dento \& por fora, no ritmo das ondas. Eles podem ser lidos consecutivamente? Não sei nada obre aquilo". WOOLF, Virginia. The diary of Virginia Woolf Vol3 1925-1930. Anne Olivier Bell (Ed.). New York: Harvest, 1980. p. 312. Tradução nossa.

96 “A vida é agradável. A vida é boa. O simples processo segundo o qual decorre é satisfatório." Ibid., p. 163.

97 "Sim, mas de súbito escutamos o tiquetaque de um relógio. Nós que tínhamos estado imersos neste mundo, apercebemo-nos da existência de outro. É doloroso. Foi o Neville quem alterou o nosso tempo. Ele, que pensara com o tempo ilimitado do espírito, o qual se estende como um relâmpago desde Shakespeare até nós". Ibid. p.171.
} 
shrouded with solemn cloud-reflections"98. Já Louis Kronenberger, do New York Times Book Review, expressa outra opinião sobre a obra: “ Mrs. Woolf has not only passed up superficial reality; she has also passed up psychological reality. She is not really concerned in The Waves with people, she is hardly concerned in the prosaic sense of humanity: she is only concerned with symbols"99.

De acordo com Lucia Miguel Pereira, The waves extrapola o equilíbrio entre os aspectos psicologizantes das personagens e a representação verossímil da realidade circundante, devido a uma alta carga de intimismo que chega a romper com a fluidez da prosa romanesca para dar lugar a uma força narrativa associada às reflexões das personagens, ou seja, a narratividade típica do romance é devastada pelas confissões psico-emocionais das personagens.

Outro aspecto relevante é que, no romance, há um predomínio drástico da individualidade, em detrimento do caráter universalizante que, segundo Pereira, a personagem deveria expressar. Em "Dualidade de Virginia Woolf", a crítica comenta: “(..) em The waves, seis destinos humanos se cumprem enquanto, em prelúdios descritivos que alternam com os diálogos das personagens, amanhece e anoitece no mar: simbolismo um tanto sediço; a existência de cada um de nós vista como um dia no mundo" 100 .

No ensaio “Assombração", é claro o posicionamento de Pereira em relação à produção ficcional da escritora inglesa, com exceção de To the lighthouse, ao afirmar

\footnotetext{
98 "Sua [Virginia Woolf] total intenção é descrever a fluidez da experiência humana (...). Seu livro brilha com milhares de diamantes, e, às vezes, é coberto com reflexões interiores importantes”. NICOLSON, Harold. Virginia Woolf - The critical heritage. MADJUMAR, Robin/McLAURIN, Allen. (Ed.). Boston: Routledge\&Keagan, 1975. p. 266. Tradução nossa.

99 “'A Sra. Woolf não somente não considera a realidade superficial; ela também não considera a realidade psicológica. Ela não está realmente preocupada em As Ondas com as pessoas, ela não está nem um pouco preocupada com o sentido prosaico da humanidade: ela só está preocupada com os símbolos”. Ibid., p. 274. Tradução nossa.

${ }^{100}$ PEREIRA, Lucia Miguel. Escritos da maturidade. Rio de Janeiro: Grafia, 2005. p. 109.
} 
que nos romances de Woolf "esse desapego da realidade é (...) constante (...) e dele decorre sem dúvida a sensação de artificialidade (...) a falta de substância de livros como The Waves [em ] que não quis nunca ver as pessoas em si mesmas, e sim através do modo pelo qual se refletem na sensibilidade do observador (...)"101.

Se, por um lado, a crítica brasileira não aprecia grande parte da produção romanesca de Woolf, por outro, o mesmo não ocorre com a obra contística da escritora inglesa. Nesse mesmo ensaio, ela afirma que Virginia Woolf tende "muito mais [para] o gênero livre do sketch onde se pode pôr tudo, onde tudo cabe, do que o romance (...)"102. O conto apresenta-se para ela como um espaço em que a imaginação criadora, em relação aos processos psíquicos, pode atingir um alto grau; admite "um mundo que não é o quotidiano, onde as almas são muito mais sensíveis que os corpos”103.

De fato, se nos remontarmos à definição de conto, encontraremos aspectos que nos remetem à visão de Pereira, como afirma Nádia Batella Gotlib em Teoria do conto: “O conto (...) não se refere só ao acontecido. Não tem compromisso com o evento real. Nele, realidade e ficção não têm limites precisos" ${ }^{104}$.

Portanto, no conto Lucia Miguel Pereira se alinha com a autora de Mrs Dalloway, no sentido de privilegiar uma característica que acreditava ser fundamental nesse gênero literário: o poder de sugestão. Pereira considerava essa faceta muito importante, pois era a demonstração do trabalho criativo do autor, o uso da imaginação a serviço da elaboração literária. A crítica nos dá um exemplo no ensaio "São Bernardo e o mundo seco de Graciliano Ramos", em que o poder da sugestão contribui para a boa qualidade de um texto literário ao preenchê-lo com cenas que incitam a imaginação do

\footnotetext{
${ }^{101}$ Ibid., p.127.

102 Ibid., p.127.

${ }^{103}$ Ibid., p. 125.

${ }^{104}$ GOTLIB, Nádia. Teoria do conto. São Paulo: Ática, 1998. p. 12.
} 
leitor. Como exemplo, Pereira transcreve uma passagem em que o narrador procura se recordar de sua mulher, ao anoitecer e "vai insensivelmente confundindo o presente e o passado. 'O tic-tac do relógio diminuiu (...) Digo baixinho: - Madalena! A voz dela me chega aos ouvidos. Não, não é aos ouvidos. Também já não a vejo com os olhos"”105.

O conceito de recriação da realidade na obra literária, minimamente deformada, é explicado pela crítica brasileira em um ensaio publicado no Correio da Manhã, sobre a escritora inglesa Rosamond Lehmann ${ }^{106}$. Ela participou do "Bloomsbury Group", o grupo constituído por intelectuais, filósofos e artistas, entre os quais Virginia Woolf, na primeira metade do século XX. Eles se encontravam no bairro homônimo, em Londres, e suas discussões giravam em torno de literatura, economia e questões sociais. A estética de Lehmann se assemelha à de Woolf, no sentido de descrever os pensamentos e sensações das personagens em um tempo não-linear e sem uma preocupação factual.

Diferencia-se sensivelmente do conceito romanesco de Pereira, que comenta: “O que (...) não se aceita, é que a vida toda, em todos os seus aspectos, tenha a mesma alta tensão, a mesma difusa efervescência. Não são apenas as criaturas, é tudo (...) os objetos inanimados que participam dessa exaltação, que banham numa atmosfera imprecisa e fluida"107. Essa "atmosfera fluida" de Lehmann, que se assemelha à de Woolf, é o ponto central de discordância entre as escritoras inglesas e Pereira no romance. A partir desse contraponto, a crítica brasileira expõe seu conceito de realidade: “(...) ninguém quererá fazer da arte a cópia da realidade; todo artista deforma - os mesmos chamados realistas deformaram tanto... Mas a deformação há de ser feita para

\footnotetext{
${ }^{105}$ PEREIRA, Lucia Miguel. A leitora e seus personagens. Rio de Janeiro: Grafia, 2005. p. 110.

${ }^{106}$ Seus romances abordavam as tensões e conflitos femininos, como por exemplo: Dusty answer (1927), Invitation to the waltz (1932), The weather in the streets (1936) e The ballad and the source (1944). Também publicou contos e traduções.

${ }^{107}$ PEREIRA, Lucia. Escritos da maturidade. Rio de Janeiro: Grafia, 2005. p. 145.
} 
conseguir a maior realidade dentro do plano da obra, isto é, há de acentuar os traços essenciais, aqueles que marcam o sentido" ${ }^{108}$.

Embora a técnica de descrição dos pensamentos já tenha sido utilizada no romance realista do século XIX, há uma grande diferença em relação à narrativa de Lehmann e Woolf. No romance realista essa prática era elaborada por um autor onisciente que via nesse procedimento a possibilidade de maior verossimilhança. Já nas autoras inglesas, os pensamentos nos são apresentados aleatoriamente no fluxo de consciência das personagens.

É fundamental que reafirmemos o conceito de recriação da realidade no romance para Lucia Miguel Pereira. A própria crítica escreve no artigo sobre Jane Austen que "causa prazer ver como é limpo o seu trabalho, como tudo lhe sai firme e bem acabado. Nada é vago, nada é desarrumado nos seus livros. Cada pessoa surge bem ajustada ao que a cerca, os episódios se adaptam perfeitamente às circunstâncias em que ocorrem"109. Pereira elogia a técnica narrativa de Jane Austen, pois os textos da autora inglesa enfocam questões do cotidiano, principalmente do universo feminino, além de uma abordagem externa e psicológica das personagens de forma linear, o que reforça o caráter realista da narrativa.

Já no conto, como mencionamos, o comprometimento com a realidade é variável, pode ir desde a representação do cotidiano até o sobrenatural. No ensaio “Assombração" Pereira expõe seu ponto de vista sobre esse gênero literário ao escolher o conto "The mark on the wall”. Ele pertence à obra A haunted house, uma publicação póstuma compilada por Leonard Woolf. Trata-se de um livro composto de alguns contos da obra Monday or Tuesday, de 1921, além de outros contos publicados em

\footnotetext{
${ }^{108}$ Ibid., p. 145.

${ }^{109}$ Ibid., p. 99.
} 
revistas e ainda cinco outros inéditos. O conto segue os pensamentos de uma narradora que tece diferentes explicações para uma marca na parede, inserindo e ampliando o poder do sugestionamento.

Segundo a crítica brasileira, a importância do texto "está em mostrar o próprio processo da composição de Virginia Woolf”, ${ }^{\prime 10}$, pois há nele a utilização de uma técnica recorrente da escritora inglesa - a fragmentação do texto expressa por pensamentos aparentemente caóticos que fluem e se fundem. Um excerto de "The mark on the wall" dá a dimensão que Lucia Miguel Pereira percebe como elemento de sugestão na recriação da realidade, que impulsiona o conto de Woolf:

In certain lights that mark on the wall seems actually to project from the wall. Nor is it empty circular. I cannot be sure, but it seems to cast a perceptible shadow, suggesting that if I ran my finger down that strip of the wall it would, at a certain point, mount and descend a small tumulus like those barrows on the South Downs which are, they say, either tombs or camps. ${ }^{111}$

Esse trecho é exemplo da qualidade reconhecida pela crítica brasileira do texto de Woolf em que "Uma insignificância qualquer lhe desperta toda uma série de imagens, sem unidade aparente, que se vão provocando umas às outras (...)"112 e serve para Woolf como um ponto de partida e chegada para dar vazão às reflexões do narrador.

Na passagem acima é clara a referência ao poder de sugestão evocado pelo texto, na busca da narradora pela definição da marca na parede. Além disso, a ironia

\footnotetext{
${ }^{110}$ Ibid., p.127.

111 "Sob certas luzes essa marca na parede parece na verdade se projetar da parede. Não é perfeitamente circular. Não posso ter certeza, mas parece lançar uma sombra perceptível, sugerindo que, se eu corresse o dedo para baixo, naquela faixa da parede, a um certo ponto ele iria subir e descer por um montículo, liso como os de South Downs, que ou bem são túmulos, segundo dizem, ou bem, acampamentos".WOOLF, Virginia. V.Wool f-contos completos. Tradução Leonardo Fróes. São Paulo: Cosac Naify. p. 109-110.

112 PEREIRA, Lucia Miguel. op. cit., p.127.
} 
expressa no fim do conto surpreende o leitor com uma resposta simples, após tantas reflexões e questionamentos:

Oh! dear me, the mystery of life; the inaccuracy of thought! The ignorance of humanity! To show how very little control our possessions we have- what an accidental affair is living is after all our civilization (...) Ah, the mark on the wall! It was a snail. ${ }^{113}$

A fim de esclarecer a sutileza estética expressa pelo conto, Pereira nos dá o exemplo da leitura de quadros de Portinari:

Quando, por exemplo, contemplamos o já clássico retrato que Portinari fez de sua Mãe (...) ou (...) de Manuel Bandeira, o que realmente nos importa não é a semelhança com os modelos (...). O que empolga, o que prende o olhar e o obriga a voltar sempre às telas, a querer guardá-las na retina, é que evocam, e que se desdobra para além, muito além da representação pictórica: a visão completa de existências devotadas, uma das atividades essenciais da condição humana (...) outra ao ato espiritual por excelência - a criação poética 114

Ao fazer essa comparação, Pereira reforça a importância do trabalho artístico, no processo de transposição da realidade norteado pela sensibilidade, pela sugestão, seja no campo das artes plásticas, seja na literatura. No caso do conto, segundo ela, esse trabalho é aguçado pelo livre uso da imaginação.

Outro exemplo, em A haunted house, da estética de Woolf que posteriormente marcaria sua produção romanesca na utilização da técnica de apresentação do fluxo dos pensamentos das personagens está em “An unwritten novel” em que, em um trem, o narrador senta-se na frente de uma mulher aparentando infelicidade, a chama de Minnie Marsh e começa a criar uma história sobre ela ao imaginar sua vida. No momento

\footnotetext{
113 “Oh! meu Deus, o mistério da vida! A inexatidão do pensamento! A ignorância da humanidade! Para mostrar como é pouquíssimo o controle que temos sobre nossas posses - sendo questão acidental que este modo de vida seja afinal nossa civilização (...) ah, a marca na parede! Era um caramujo". WOOLF, Virgina. op. cit., p. 106/115.

${ }^{114}$ PEREIRA, Lucia Miguel. Escritos da maturidade. Rio de Janeiro: Grafia, 2005. p. 126.
} 
seguinte, interrompe a personagem quando sai do trem para encontrar seu filho. Este conto dialoga com "The mark on the wall”, pois lá também Virginia Woolf se utiliza da imagem de personagens sentadas em frente a estranhos. Isto representa a dificuldade de comunicação que as personagens enfrentam, em um processo de espelhamento. Porém, aqui, não se trata da reflexão sobre um objeto, mas sobre outros seres humanos e suas possibilidades de escolhas existenciais.

Em “An unwritten novel”, essa situação do trem é descrita da seguinte forma:

Five faces opposite (...) Marks of reticence are on all those faces; lips shut, eyes shaded, each one of the five doing something to hide or stultify his knowledge. (...) the terrible thing about the fifth is that she does nothing at all. She looks life. Ah, but my poor, unfortunate woman, do play the game - do, for all our sakes, conceal it! $!^{115}$

Já em “The mark on the wall”, a mesma situação é nos apresentada como:

As we face each other in omnibuses and underground railways we are looking into the mirror; that accounts for vagueness, the gleam of glassiness, in our eyes. And the novelists in future will realise more and more the importance of these reflections (...) leaving the description of reality more and more out of their stories $(\ldots)^{116}$.

Woolf cria em "An unwritten novel” um ritmo acelerado de narração dos detalhes da história em um crescendo, no qual a imaginação se apodera de um narrador preocupado em demonstrar os pensamentos das personagens absorvidas por esse fluxo caótico:

\footnotetext{
115 "Cinco rostos opostos (...) sinais de reticência: boca fechada, olhos sombrios, cada um dos cinco fazendo alguma coisa para ocultar ou estultificar seu conhecimento (...) o que há de terrível em relação ao quinto é que ela não faz absolutamente nada. Fica vendo a vida. Ah, minha pobre, infeliz mulher, não deixe de entrar no jogo-e, em atenção a todos nós, disfarce bem!”. WOOLF, Virginia. op. cit., p.149.

116 "Quando nos olhamos face a face, nos ônibus e trens subterrâneos, é no espelho que nós estamos olhando; o que explica a vaguidão, o brilho de vidro, em nossos olhos. E os romancistas do futuro dar-seão cada vez mais conta da importância dessas reflexões (...) deixando a descrição da realidade cada vez mais fora de suas histórias (...)" Ibid. p.108.
} 
That's the man's way; that's the sound that reverberates; that's St. Paul's and the motor-omnibuses. (...) Oh, Moggridge, you won't stay? You must be off? Are you driving through Eastbourne this afternoon in one of those little carriages? Are you the man who's walled up in green cardboard boxes $(\ldots)^{117}$.

A narradora reflete sobre seu próprio vazio e não vê o mundo como um local em que possamos nos relacionar, mas para ela as pessoas só existem para seu entretenimento. Essa característica de centrar-se em si mesma será uma marca de Woolf na elaboração de personagens romanescos, dos quais Mrs Dalloway é um exemplo.

Esse conto foi a primeira tentativa de Woolf de captar os pensamentos das personagens e utilizar essa técnica em seus romances posteriores, como afirma em uma carta a Ethel Smyth, compositora e uma das líderes do movimento sufragista no começo do século XX:

The Unwritten Novel (...) showed me how I could embody all my deposit of experience in a shape that fitted it -not that I have ever reached that end; but anyhow I saw, branching out of the tunnel I made, when I discovered that method of approach, Jacobs Room [1922], Mrs Dalloway[1925] etc- How I trembled with excitement $(\ldots)^{118}$.

Ainda em seu diário de 26 de janeiro de 1920, ela também destaca a importância de alguns contos que serão decisivos para sua produção romanesca: “(...) but conceive mark on the wall, K.[ew]. G.[ardens]. \& unwritten novel taking hands \&

\footnotetext{
117 "Isto é o jeito de homem; isto é o som que reverbera; isto é a basílica de São Paulo e os ônibus a motor (...) Oh, Moggridge, você então não vai ficar? Tem de sair? Vai passar por Eastbourne hoje à tarde num desses coches apertados? É você que aí vai emparedado numa caixa de papelão verde (...)”. Ibid., p. 158159.

118 "Um romance não escrito (...) me mostrou como eu poderia corporificar todo meu depósito de experiência em uma forma que se lhe ajustasse - não que já tenha atingido o objetivo; mas de qualquer forma eu vi, ramificando do túnel que fiz, quando eu descobri aquele método de abordagem, O quarto de Jacob[1922], Mrs Dalloway [1925] etc. - Como eu tremi de emoção". WOOLF, Virginia. Congenial spirits. Joanne Trautmann (Ed.). New York: Harvest, 1990. p. 274. Tradução nossa.
} 
dancing in unity (...). I see immense possibilities in the form I hit upon more or less by chance 2 weeks ago"119.

Esses contos de Monday or Tuesday, em particular , "The mark on the wall" e "An unwritten novel", foram importantes para o que denominou "the tunneling process", a que já nos referimos anteriormente, de modo a presentificar o passado e apresentar o fluxo do pensamento das personagens, como ocorre, por exemplo, em Mrs Daloway. Monday or Tuesday explora profundamente a complexidade dos processos mentais. Esse mesmo título será utilizado em 1925, no ensaio "Modern fiction", uma reflexão sobre seu processo de criação, além de apresentar um novo modo de produção ficcional:

Examine for a moment an ordinary mind on an ordinary day. The mind receives a myriad impressions- trivial, fantastic, evanescent, or engraved with the sharpness of steel. From all sides they come, an incessant shower of innumerable atoms; and as they fall, as they shape themselves into the life of Monday or Tuesday, the accent falls differently from of old; the moment of importance came not here but there $(\ldots)^{120}$

Para Lucia Miguel Pereira, essa técnica de Woolf, que propõe uma reflexão de cunho existencial, é cabível no conto, pois nele, segundo a crítica brasileira, o desbravamento da alma humana que Woolf elabora demonstra o trabalho da sensibilidade do artista. Pereira sempre reitera em sua crítica literária a importância do trabalho criador. Nessa empreitada, o artista pode “(...) lidar com relações em vez de

\footnotetext{
119 "Mas conceber a marca na parede, K.[ew]. G.[ardens]. \& romance não escrito dando as mãos e dançando em harmonia (...). Eu vejo imensas possibilidades na forma que descobri mais ou menos por acaso há duas semanas". WOOLF, Virginia. The diary of Virginia Woolf. Vol.2 1920-1924. Annie Olivier Bell (Ed.). New York: Harcourt Brace Jovanovich, 1978. p. 14. Tradução nossa.

120 "Examine por um momento uma mente comum e um dia comum. A mente recebe uma miríade de impressões - triviais, fantásticas, evanescentes ou esculpidas com a firmeza do aço. De todos os lados elas vêm, uma incessante chuva de inumeráveis átomos; e enquanto caem, enquanto se acomodam à vidinha de segunda ou terça-feira, a ênfase recai diferentemente de antigamente; o momento importante aparece não aqui, mas ali (...).”. WOOLF, Virginia. O leitor comum. Tradução Luciana Viégas. Rio de Janeiro: Grafia, 2007. p. 75.
} 
ações, sem que isso revele importância para abranger a natureza humana em sua totalidade"121. Apesar de não considerar o romance como o gênero de tais arroubos da imaginação, é no conto que a crítica brasileira vê tal possibilidade.

Essa diferenciação entre a produção romanesca e a contística também acontece, segundo ela, com um autor de sua grande admiração: Machado de Assis. Também a ele tece algumas críticas em relação à elaboração romanesca, como em Iaiá Garcia, em que, segundo Pereira, "ainda [está] enleado no convencionalismo"122, mas reconhece que "foi como contista que o escritor deu toda a sua medida", pois o conto permite que explore os pormenores das personagens. Ao definir o conto como "o flagrante de um indivíduo em determinada circunstância, ou sob determinado aspecto", ela admite uma "visão parcial" da personagem em contraponto com a "visão global"123 do romance. Ainda reforça o caráter positivo do conto, pois uma vez que ele se detém mais minuciosamente na personagem, propicia um "olhar mais concentrado" no sentido de captar a essência humana. Em acréscimo, a crítica brasileira ressalta na obra de Machado o caráter universalizante que a obra do escritor criou a partir da construção de personagens locais.

Woolf apreende um momento do pensamento de suas personagens, o "flagrante". Penetra nos devaneios das personagens em seus questionamentos existenciais, ou seja, demonstra as aflições que se estendem a todos os seres humanos. Pereira reconhece seus contos como exemplos do "mundo silencioso das transmissões

\footnotetext{
${ }^{121}$ PEREIRA, Lucia Miguel. Escritos da maturidade. Rio de Janeiro: Grafia, 2005. p. 127.

${ }^{122}$ PEREIRA, Lucia Miguel. Prosa de ficção. Belo Horizonte: Itatiaia; São Paulo: EDUSP, 1988. p. 67.

${ }^{123}$ Ibid., p.99.
} 
de pensamentos, das premonições, das intuições, dos mudos antagonismos e das compreensões mudas" ${ }^{\prime 124}$.

Portanto, Lucia Miguel Pereira vê o conto onde se localiza o espaço do fragmentário, da hegemonia das ilações decorrentes de questionamentos existenciais e do sugestionamento. Aprecia o trabalho de Woolf que se caracteriza por uma subjetividade acentuada na expressão dos pensamentos de suas personagens, sem uma preocupação factual e cronológica. No conto, Pereira extravasa o aspecto humanístico que, no romance, considera importante aliado à representação da realidade. É na contística que Pereira afasta-se radicalmente de seus contemporâneos centrados na especificidade local.

Enfim, o "mundo" que Lucia Miguel Pereira percebeu de Virginia Woolf a uniu à escritora inglesa nos contos. Nos ensaios também compartilharam o equilíbrio da linguagem crítica e narrativa. Somente discordaram na linguagem romanesca: Pereira ao buscar o equilíbrio entre a objetividade e a essência universalizante nas personagens e Woolf na profusão do tom intimista para chegar ao âmago da existência.

Em ambas, encontra-se a busca pela essência humana, quer seja na realidade, quer seja nos devaneios dos pensamentos. Suas trajetórias literárias as uniram como ensaístas em periódicos, romancistas, assim como na ideologia na luta pela defesa de direitos básicos negados às mulheres em suas épocas. Em outras palavras, a busca das duas escritoras da essência do humano no texto literário, através da força latente da vida, pode ser comparada à afirmação do suicida do conto "O espelho", de Machado de

${ }^{124}$ PEREIRA, Lucia Miguel. Escritos da maturidade. Rio de Janeiro: Grafia, 2005. pp. 127-128. 
Assis, ao acreditar que sua alma poderia se esconder em um calçado: "Sim, a felicidade é um par de botas."

${ }^{125}$ ASSIS, Machado de apud PEREIRA, Lucia Miguel. Prosa de ficção. Belo Horizonte: Itatiaia; São Paulo: EDUSP, 1988. p. 91. 
CAPÍTULO III - A CONSTRUÇÃO DO TEMPO EM MRS DALLOWAY, TO THE LIGHTHOUSE E AMANHECER 
Nesse capítulo analisaremos três romances, Mrs. Dalloway e To the lighthouse, ambos de Virginia Woolf, e Amanhecer, ${ }^{1}$ de Lucia Miguel Pereira, de modo a comparar como as autoras trataram um aspecto especialmente relevante para sua estética literária: a construção do tempo ficcional.

No processo da concepção romanesca, a elaboração temporal é de fundamental importância, uma vez que está ligada à experiência humana. Hans Meyerhoff afirma em $O$ tempo na literatura:

O que somos, nós o somos apenas no tempo e através dele; mas somos também constantemente modificados no tempo e pelo tempo. O tempo nos faz e nos desfaz, tanto no sentido físico da mudança da estrutura celular do corpo- completamente renovada, afirma-se, a cada período de anos- e no sentido psicológico de um fluxo de consciência constantemente mutável. ${ }^{2}$

Em Mrs. Dalloway, a concepção do tempo é fragmentada, de forma a centrar-se em uma temporalidade psicológica que posiciona o elemento humano e suas questões existenciais como o centro das preocupações do autor. Esse tipo de abordagem é resultado das mudanças científicas, tecnológicas e sociais e também da guerra que avassalou a Europa na época de Woolf. Tal compreensão temporal se expressará no romance pelo uso do fluxo de consciência, uma técnica que Woolf denominou "tunneling process", na qual predomina a apresentação dos pensamentos das personagens em um tempo não cronológico, o que possibilita a união do presente com o passado por meio das reflexões e rememorações. Desde o começo de sua elaboração, Woolf estava determinada a utilizá-lo, sem se importar com sua recepção crítica ao utilizar essa abordagem, uma vez que rompe com a linearidade temporal, como verificamos em seu diário de 1922: "I have made up my mind that I'm not going to be so popular, \& so genuinely that I look upon disregard or

\footnotetext{
${ }^{1}$ PEREIRA, Lucia Miguel. Amanhecer. Rio de Janeiro: Livraria José Olympio, 1938. Utilizaremos a primeira edição, de 1938, pois, embora seus romances tenham sido reeditados em 2006, acreditamos que aquela seja a mais indicada para nossa análise. Assim, faz-se necessário informar que manteremos a grafia originalmente usada na referida edição.

${ }_{2}^{2}$ MEYERHOFF, Hans. O tempo na literatura. Tradução Myriam Campello. São Paulo: McGraw-Hill, 1976. p. 27.
} 
abuse as part of my bargain. I'm to write what I like; \& they're to say what they like."3 Shiv K. Kumar, explica, em Bergson and the stream of consciousness novel, que " what (...) Virginia Woolf [ calls] 'luminous halo' [life], is nothing else than those transitional phases of our mental processes which mark the merging of the past into the present, and the fading of the present into the future, thus making experience a continuum.",

Esse procedimento em Mrs. Dalloway estrutura o romance e permite que todas as ações se passem na dimensão psicológica das personagens, construindo, assim, uma temporalidade interior que põe em simultaneidade o presente e o passado:

(...) a child throwing bread to the ducks, between her parents, and at the same time a grown woman coming to her parents who stood by the lake, holding her life in her arms which, as she neared them, grew larger and larger in her arms, until it became a whole life, a complete life, which she put down by them and said, 'This is what I have made of it! This! ${ }^{5}$

Além de dar ao leitor essa ideia de concomitância, ainda proporciona uma maior visibilidade dos sentimentos experimentados pelos personagens.

Outro ponto ligado ao "tunneling process" é a interação entre pensamentos, como aponta Howard Harper em Between language and silence-the novels of Virginia Woolf:

The transitions from one mind to another, and from individual minds to a larger cultural awareness, enhance the feeling that human consciousness transcends the limitations of individual minds. The

\footnotetext{
3 “Eu decidi que não serei muito popular, \& tão genuinamente que considero o desprezo e o insulto como parte da minha barganha. Vou escrever o que eu gosto; \& eles vão dizer do que gostam." WOOLF, Virginia. The diary of Virginia Woolf Vol 2. 1920-1924. New York: Harcourt Brace Jovanovich, 1978. p. 168. Tradução nossa.

4 “O que (...) Virginia Woolf [chama de] halo luminoso [a vida] nada mais é do que aquelas fases de transição de nossos processos mentais que assinalam a fusão do passado no presente, e o desaparecimento do presente no futuro, tornando, desse modo, a experiência um continuum.” KUMAR, Shiv K. Bergson and the stream of consciouness novel. New York: New York University Press, 1963. p. 15. Tradução nossa.

5 ““(...) uma menina, que arrojava pão aos patos, na companhia dos pais, e ao mesmo tempo uma mulher que se dirigia para os seus pais junto ao lago, carregando nos braços a própria vida que ia crescendo à medida que se lhes aproximava, até se tornar uma vida inteira, uma vida completa, que ela pôs ante eles, dizendo:' Foi isto o que eu fiz da minha vida! Isto!'”. WOOLF, Virginia. Mrs. Dalloway. Tradução Mário Quintana. Rio de Janeiro: Nova Fronteira, 1980. p. 44.
} 
significance of an individual human life, Clarissa once told Peter, is "completed" by other people, and even by places. That, she sensed, is the secret of immortality, the perpetuation of human meaning beyond the limitations of individual lives. ${ }^{6}$

Essa união pode ser observada na ligação entre Clarissa e Septimus, que, embora nunca tenham se encontrado pessoalmente, compartilham o mesmo sofrimento causado pelas atitudes da sociedade: Septimus fora uma vítima da guerra e Clarissa sentia-se culpada por pertencer a uma classe dominante que, muito possivelmente, encontrava-se cega diante das penúrias sociais. Sua reflexão, após saber do suicídio de Septimus, dirige seus pensamentos em direção aos do suicida:

Somehow it [Septimus' death] was her disaster-her disgrace. It was her punishment to see sink and disappear here a man, there a woman, in this profound darkness, and she forced to stand here in her evening dress. $^{7}$

Septimus Warren Smith, pertencente à classe trabalhadora, voltou traumatizado da guerra, o que acabou por torná-lo insensível aos sentimentos dos outros. Retirou-se do mundo físico e passou a viver em seu próprio mundo interior, onde vê e ouve coisas que não estão presentes e conversa com seu grande amigo, Evans, morto na guerra.

Aparentemente, distingue-se de Clarissa, mas possui muitas características que o aproximam dela. Na realidade, poderia ser quase considerado seu duplo. Ambos apreciam as obras de Shakespeare e o que mais os une é o medo da opressão: no caso de Septimus, pela guerra, e no de Clarissa, pela sociedade. Os delírios de Septimus trazem à tona os princípios políticos que regem a sociedade inglesa, uma vez que "London has swallowed up

\footnotetext{
6 "As transições de uma mente para a outra, e de mentes individuais para uma maior percepção cultural intensificam o sentimento de que a consciência humana transcende as limitações de mentes individuais. $O$ sentido de uma vida humana individual, Clarissa, uma vez disse a Peter, se 'completa' por outras pessoas, mesmo por lugares. Este, ela ponderou, é o segredo da imortalidade, a perpetuação do sentido humano para além dos limites das vidas individuais." HARPER, Howard. Between language and silence. Baton Rouge: Louisiana State University Press, 1982. p. 117.

7 "De certo modo, era aquilo [o suicídio de Septimus] um desastre dela própria, uma catástrofe sua. Eralhe um castigo ver afundar e desaparecer aqui um homem, ali uma mulher, naquela profunda escuridão, enquanto ela era forçada a permanecer ali, com seu vestido de gala. (...) Nunca fora inteiramente admirável." WOOLF, Virginia, op. cit., p.178.
} 
many millions of young men called Smith." ${ }^{8}$ Além disso, os pensamentos dele são colocados paralelamente aos de Clarissa, o que nos faz pensar sobre a linha tênue que separa a sanidade da insanidade, como afirma Virginia Woolf em seu diário ao comentar sobre a fatura do romance: "Mrs. Dalloway has branched into a book; \& I adumbrate here a study of insanity \& suicide: the world seen by the sane \& the insane side by side something like that."9

A morte de Septimus é o auge da comunhão entre ele e Mrs. Dalloway, pois o suicídio foi o modo que encontrou para escapar de seus problemas e, ao mesmo tempo, acaba sendo o gesto que fundamentalmente ajuda Clarissa a refletir sobre a sociedade em que vive:

She felt somehow very like him- the young man who had killed himself. She felt glad that he had had done it; thrown it away (...). The clock was striking. The leaden circles dissolved in the air. But she must go back. She must assemble [the guests]. ${ }^{10}$

Retomando a questão da temporalidade, as batidas do Big Ben, que representam as marcas de uma realidade exterior às ações que se desencadeiam nas mentes dos personagens, conduzem a tessitura textual. Sempre presentes, essas batidas que anunciam o tempo cronológico deflagram, simultaneamente, o desfiar das reflexões, das recordações e do intimismo pessoal. Ao permearem o romance, demonstram a validade da importância do tempo factual, material e histórico em conexão ao fluxo do pensamento na atemporalidade. É como se estivessem sempre a lembrar que o tempo psicológico vivenciado pelas personagens se diferencia do tempo cronológico, sempre preciso e exato, mas que dele sente necessidade a fim de construir uma unidade que fundamente a existência humana.

\footnotetext{
8 “Londres tragara muitos milhões de jovens chamados Smith". Ibid., p. 83.

9 "Mrs. Dalloway ramificou-se em um livro; \& eu prenuncio aqui um estudo sobre a insanidade \& suicídio: o mundo visto pelos sãos \& insanos lado a lado- algo assim.” BELL, Anne Olivier. (Ed.). The diary of Virginia Woolf. Vol. 2 1920-1924. New York: Harcourt Brace Jovanovich, 1978. p. 107.

10 "Sentia-se de certo modo como ele... o jovem que havia se suicidado. Sentia-se contente de que ele tivesse feito aquilo; alijado a vida (...). O relógio batia. Os pesados círculos se dissolviam no ar. Mas tinha de voltar para junto deles. Tinha de reuni-los [os convidados].” WOOLF, Virginia, op. cit., p. 135.
} 
Nesse contraponto, acaba por evidenciar a interdependência de duas realidades consideráveis: a externa, constantemente a apontar a fluidez do tempo, e a interna, que, formada pela confluência do presente, passado e futuro, marca a história de vida de cada um.

A circularidade do tempo na construção romanesca é expressa em uma passagem na qual uma mendiga, na estação de metrô de Regent's Park, canta uma canção que traz, em pensamento, o retorno de seu amado perdido no tempo. O passado conflui, então, para o presente. É interessante observar que o presente marcado pelas pessoas que passam em frente ao metrô desaparece instantaneamente e mergulha num estado da natureza anterior à civilização, transformando-se, por sua vez, em passado:

(...) a man who had loved her. But the passage of ages had blurred the clarity of that ancient May day; the bright-petalled flowers were hoar and silver frosted; and she no longer saw, when she implored him (as she did now quite clearly) 'look in my eyes with thy sweet eyes intently,' she no longer saw brown eyes, black whiskers or sunburnt face, but only a looming shape, a shadow shape, to which, with the bird-like freshness of the very aged, she twittered 'give me your hand and let me press it gently' (Peter Walsh couldn't help giving the poor creature a coin as he stepped into his taxi), 'and if someone should see, what matter they? She demanded; and her fist clutched at her side, and she smiled, pocketing her shilling, and all peer inquisitive eyes seemed blotted out, and the passing generations- the pavement was crowded with bustling middle-class people-vanished like leaves, to be trodden under, to be soaked and steeped and made mould $(\ldots)^{11}$.

A preponderância do uso do fluxo de consciência no romance possibilita a exposição dos pensamentos das personagens e deixa os fatos da realidade em um segundo

\footnotetext{
11 “(...) um homem que a havia amado. Mas a passagem dos séculos empanava a claridade daquele antigo dia de maio; as folhas de brilhantes pétalas estavam brancas de geada; e ele não mais via, quando lhe implorava (como o fazia agora claramente): 'olha bem para mim com esses teus doces olhos', não mais via olhos castanhos, negros bigodes, ou curtida face, mas uma vaga, uma sombria forma, para a qual, com a frescura de pássaro da velhice extrema, ainda gorjeava 'dá-me essa mão e deixa-me apertá-la' (Peter Walsh não pôde deixar de dar uma moeda à pobre criatura, ao tomar o táxi), 'e se alguém nos vê, que importa?', perguntava ela; e sua mão fechou-se, e ela sorriu, embolsando o xelim, e todos os olhos curiosos pareceram apagar-se, e as gerações que passavam - o pavimento estava coberto de afanosos pequenos burgueses - desapareciam, como folhas atropeladas, molhadas e convertidas em barro (...)". Ibid., p. 81.
} 
plano, uma vez que Woolf opta por uma representação psíquica. A ruptura com a representação da realidade exterior não se enquadra na concepção estética romanesca de Pereira, como afirma no ensaio "O Big Ben e o carrilhão fantasista". Ela se refere a Mrs. Dalloway como um "acúmulo de sugestões, de impressões, de recordações, de associações mentais, a anotação prolixa de cada minuto, como que impossibilitam a apreciação em conjunto.Tudo fica dividido, pulverizado." 12

No rumo de nossas considerações a respeito da coexistência/oposição do tempo cronológico e do psíquico, é importante acrescentar que, nesse mesmo ensaio, Lucia Miguel Pereira faz referência a um "carrilhão fantasista cujos sons (...) trazem (...) pensamentos informulados (...) frivolidades". ${ }^{33}$ Este outro relógio é a metáfora de um tempo descompassado, incerto, que se opõe à exatidão das horas marcadas pelo Big Ben, e aponta para os pensamentos fragmentados, as rememorações, as recordações e reminiscências que constituem a aparente atemporalidade do mundo psíquico. A estes pensamentos, Pereira atribuiu a designação de "quinquilharias". Uma passagem em Mrs. Dalloway ilustra a afirmação da crítica brasileira:

(...) but here the other clock, the clock which always struck two minutes after Big Ben, came shuffling in with its lap full of odds and ends, which it dumped down as if Big Ben were all very well with his majesty laying down the law, so solemn, so just, but she must remember all sorts of little things $(\ldots)^{14}$.

Podemos ainda dizer que o tempo no romance também se mostra ameaçador, e é nesse instante que ele assume uma concepção cronológica de construção literária não mais como um motivador da temporalidade psíquica, mas como o ente devastador da vida. A

\footnotetext{
${ }_{12}^{12}$ PEREIRA, Lucia Miguel. Escritos da maturidade. Rio de Janeiro: Graphia, 2005. p. 118.

${ }^{13}$ Ibid., p. 116.

14 “(...) Mais eis que o outro relógio, o relógio que sempre batia dois minutos depois do Big Ben, entrou com suas mangas cheias de bagatelas, que se despejou no chão, como se ao Big Ben, tão solene, tão injusto, coubesse ditar a lei, com a sua majestade, ao passo que ele devia lembrar toda espécie de coisas insignificantes (...)." WOOLF, Virginia, op. cit., p. 124.
} 
lembrança de seu passar, sempre alertada pelo sino do Big Ben, é a lembrança da finitude. Um exemplo dessa faceta da temporalidade é demonstrada na preocupação de Clarissa quando se refere a Lady Bruton, dez anos mais velha que ela:

But she [Clarissa] feared time itself, and read on Lady Bruton's face, as if it had been a dial cut in impassive stone, the dwindling of life; how year by year her share was sliced; how little the margin that remained was capable any longer of stretching, of absorbing as in the youthful years, the colours, salts, tones of existence (...). ${ }^{15}$

Ao contrapor To the lighthouse a Mrs. Dalloway, Lucia Miguel Pereira posiciona-se claramente a favor do primeiro, uma vez que o considera o que mais se enquadra em sua visão estética de romance - a narrativa se desenvolve de um modo mais factual, com ações mais sequenciadas, caracterizando, assim, um antes e um depois no transcorrer dos eventos, em que a passagem do tempo é mais perceptível, a trama se desenrola de maneira mais linear para o leitor. Segundo a crítica brasileira, em To the lighthouse, "o tempo - a sua principal personagem - é como que visível, sensível como uma corrente, como uma lufada de vento; as emoções se gravam nos rostos, nos modos das personagens." 16

To the lighthouse trata a relação entre o presente e o passado de modo que a circularidade temporal se relacione muito mais claramente com o tempo cronológico do que aquela percebida em Mrs. Dalloway, o que resulta em uma impressão mais nítida da realidade, contrariamente às ilações psicológicas.

Em seu diário de 1925, ao planejar a elaboração do romance, Woolf escreve que realmente queria incluir o "flight of time, \& the consequent break of unity in [its] design."17 Ela tinha por objetivo elaborar uma ficção cuja temporalidade pudesse ser compreendida

\footnotetext{
15 "Mas o tempo é o que ela [Clarissa] temia, e lia na face de Lady Bruton, como num quadrante de impassível pedra, o fluir da vida; como, ano após ano, a sua parte diminuía; quão pouco podia dilatar o que ainda restava , e absorver , como nos dias juvenis, as cores, o sabor, o tom da existência.” Ibid., p. 32. ${ }^{16}$ PEREIRA. Lucia Miguel, op. cit., p. 119.

17 “a passagem do tempo, \& a consequente quebra de unidade em [sua] concepção.” WOOLF, Virginia. The diary of Virginia Woolf. Vol 3. 1925-1930. BELL, Anne Olivier (Ed.) New York: Harcourt Brace Jovanovich, 1980.p.36.
} 
pelos dois caminhos: o da circularidade e o da linearidade. A circularidade temporal ocorre entre a primeira parte do romance (o primeiro dia em que os Ramsays e convidados estão na casa de veraneio), na qual o passeio ao farol apresenta-se como um projeto não concluído, e a terceira parte (quando os Ramsays remanescentes e seus convidados voltam à casa na ilha), que retoma a primeira como se fosse um espelhamento e conclui o passeio ao farol. Entre essas duas partes da narrativa há uma espécie de volta no tempo e, concomitantemente, há uma forte presença do tempo linear, na medida em que entre elas há um período de dez anos que separa as ações num antes e num depois. Pode-se dizer, consequentemente, que a primeira e a última partes são conectadas externamente pela circularidade temporal, como se o tempo voltasse para dar continuidade aos eventos da primeira parte, mas, internamente, as partes da narrativa se unem por uma temporalidade linear, uma vez que dez anos se passaram e provocaram profundas modificações.

A primeira parte, "A janela", deixa impressões nas personagens que serão relembradas na última parte do romance, ligando, assim, o tempo futuro ao presente que vivem naquele momento, e, esta união dos tempos, se tornará passado na sequência da narrativa. A Sra. Ramsay parece antecipar esse retorno do tempo, reatando começo e fim por meio de suas sensações:

It was windy, so that the leaves now and then brushed open a star, and the stars themselves seemed to be shaking and darting light and trying to flash out between the edge of the leaves. (...) Now one thought of it, cleared of chatter and emotion, it seemed always to have been, only was shown now, and so being shown struck everything into stability. They would, she thought, going on again, however long they lived, come back to this night; this moon; this wind; this house: and her too. $^{18}$

\footnotetext{
${ }^{18}$ Ventava, e assim as folhas deixavam às vezes entrever uma estrela, e as próprias estrelas pareciam tremular e lampejar, forcejando seu brilho entre as ourelas das folhas.(...) Agora que pensava nisso longe das conversas e das emoções, parecia-lhe que sempre existira, mas que somente então se mostrava a ela, e, ao fazê-lo, trazia tudo repentinamente à estabilidade. E, recomeçando a andar, continuou pensando: eles sempre voltarão a esta noite, por mais que vivam; a esta lua; a este vento; a esta casa; e também a ela." WOOLF, Virginia. Passeio ao farol. Tradução Luiza Lobo. Rio de Janeiro: Rio Gráfica, 1987. p. 113.
} 
Nessa passagem, é clara a relação entre o intimismo, a percepção e o movimento dialético do tempo cronológico e psicológico. Por uma espécie de presságio, a Sra. Ramsay une seu pensamento à temporalidade circular (“eles sempre voltarão a esta noite”) e à linear, como se preconizasse que o transcorrer do tempo desembocaria em profundas modificações na vida de todos, inclusive trazendo a sua própria morte naquele entreperíodo de dez anos vindouros. Essa forte união entre os dois enfoques temporais (circularidade e linearidade) também se apresenta na situação metafórica do tricotar uma meia em várias passagens. A união entre os pontos e as carreiras do tricô que formarão a meia está em direta proporção com o transcurso do tempo linear (à medida que a meia se forma), e o eterno retorno e recomeço dos próprios pontos e das carreiras, ao tempo circular. Assim, a coexistência dos dois tempos forma uma unidade explicada pela metáfora do tecer.

Com relação aos pensamentos das personagens, estes nos são mostrados dentro de uma sequência narrativa (muito embora, reiteramos, haja a coexistência/oposição entre os tempos cronológico e psicológico), isto é, não ocorrem aleatoriamente em um espaço temporal desordenado como acontece em Mrs. Dalloway, no qual há a predominância dos fluxos psicológicos. A sequência ordenada de pensamentos recebe a denominação de “moments of being”, ou seja, ocasiões em que as impressões passadas se presentificam. Como exemplo desse procedimento, depois de tricotar, a Sra. Ramsay entrega-se extasiada à admiração pelo farol, reconstruindo, assim, por meio daquele sinal luminoso, a essência mais feliz que sustentou e motivou toda sua vida. Na circularidade do tempo que o pensamento dispara, ela reencontra e reconhece seus grandes momentos. Paradoxalmente, o pensamento estanca-se, o tempo cronológico é invocado e a Sra. Ramsay parece pôr um fim a sua existência, conclamando, dessa maneira, a finitude de todo e qualquer tempo que possa, para ela, existir: 
(...) watching it [the light] with fascination, hypnotised, as if it were stroking with its silver fingers some sealed vessel in her brain whose bursting would flood her with delight, she had known happiness, exquisite happiness, intense happiness (...) and the ecstasy burst in her eyes and waves of pure delight raced over the floor of her mind and she felt, It is enough! It is enough! $!^{19}$

A interiorização das personagens, pela qual expressam seus pensamentos, pode ser observada mais na primeira e terceira partes do romance. Parece-nos um processo de espelhamento, na medida em que os fatos ocorridos na primeira parte são rememorados na terceira, de forma a caracterizar um tempo cíclico. Dessa maneira, por exemplo, em "A janela”, a Sra. Ramsay reflete: “But what have I done with my life ?"20, e na última parte, Lily, em seus pensamentos diante do quadro quase pronto da Sra. Ramsay, retoma a reflexão:

What is the meaning of life? That was all - a simple question; one that tended to close in on one with years. (...) Mrs. Ramsay saying 'Life stand still here'; Mrs. Ramsay making of the moment something permanent $(. .$.$) - this was of the nature of a revelation. In the midst of$ the chaos there was a shape; this eternal passing and flowing $(\ldots)^{21}$.

Ao trazer a Sra. Ramsay de volta do passado ao presente, Lily completa o quadro com um significado temporal circular capaz de preencher um vazio que se registra no momento de seu dia, como se negasse a passagem dos dez anos com todos seus infortúnios, como se varresse a guerra, a destruição e a morte numa perfeita negação da realidade que o tempo cronológico impôs. Tudo o que ela vê é "like curves and arabesques flourishing round a centre of complete emptiness.",22 Então, ela percebe que "those empty flourishes

\footnotetext{
19 “(...) a [a luz] olhava fascinada, hipnotizada, como se a luz fizesse surgir, com seus dedos de prata, algum veleiro em seu cérebro que, ao explodir, a inundaria de prazer - conhecera a felicidade, a mais perfeita felicidade, a intensa felicidade. (...) o êxtase inundou seus olhos, e ondas de puro deleite precipitaram-se no fundo de sua mente, e ela sentiu: 'Chega! Basta!”' Ibid., p. 67-68.

20 "Mas o que fiz de minha vida?" Ibid., p. 84.

${ }^{21}$ “"Qual o sentido da vida? Isso era tudo - uma pergunta simples; das que tendem a agrilhoar uma pessoa com o passar dos anos. (...) a Sra. Ramsay dizendo: 'Pare aqui, vida!', a Sra. Ramsay tentando transformar o momento em alguma coisa permanente - isso era da mesma natureza que uma revelação. No meio do caos havia uma forma. Esse eterno repassar e refluir (...)" Ibid., p.164.

22 "como curvas e arabescos florescendo em torno de um centro de completo vazio." Ibid. p.180.
} 
would form into shape; if they shouted loud enough Mrs. Ramsay would return. 'Mrs. Ramsay!' she said aloud, 'Mrs. Ramsay!' The tears ran down her face."23

Ao mesmo tempo em que Lily termina seu quadro, o Sr. Ramsay e seus filhos chegam ao farol, como fora programado na primeira parte da narrativa; o mesmo farol que traz em si um pouco da Sra. Ramsay, dado que ela "became the thing she looked at", ${ }^{24}$ pois, "and pausing there she [Mrs. Ramsay] looked out to meet that stroke of the Lighthouse, the long steady stroke, the last of the three, which was her stroke, for watching them in this mood always at this hour one could not help attaching oneself to one thing especially". ${ }^{25}$ Tanto Lily quanto o Sr. Ramsay e seus filhos acabam encontrando-se com as manifestações da Sra. Ramsay que foram retomadas pela presentificação do passado.

Se a ordenação dos pensamentos em um circuito temporal circular entra em harmonia com a linearidade cronológica em "A janela" e "O farol”, em "O tempo passa" há o predomínio da linearidade. A narradora evidencia a noite que precede o dia da terceira parte e o estado devastador da casa de verão associado à eclosão da guerra. Os fatos narrados acerca das profundas e trágicas mudanças que o tempo proporcionou são colocados entre parênteses, de forma bem rápida, dando-nos a impressão de certa pressa em descrever a velocidade da temporalidade que define a efemeridade da vida. Dessa maneira, por exemplo, a morte da Sra. Ramsay é assim narrada: "[Mr. Ramsay stumbling along a passage stretched his arms out one dark morning, but, Mrs. Ramsay having died rather suddenly the night before, he stretched his arms out. They remained empty.]"26 O fato é narrado tão rapidamente que não é possível saber a razão de sua morte. Também a morte de

\footnotetext{
23 "esses floreios vazios ganhariam uma forma. Se gritassem bem alto, juntos, a Sra. Ramsay voltaria. Sra. Ramsay! - disse em voz alta. - Sra. Ramsay! - as lágrimas escorriam pelo seu rosto.” Ibid., p. 182. 24 "se transformava na coisa que olhava". Ibid., p. 66.

25 "detendo-se [Sra. Ramsay], seu olhar encontrou no exterior o raio de luz do Farol longo e firme, o último dos três, que era o seu raio, pois de tanto olhar os três com o,mesmo estado de espírito, e sempre à mesma hora, não conseguia evitar ligar-se a um deles particularmente". Ibid., p. 66.

26 “(O Sr. Ramsay, andando aos tropeções no corredor, esticou os braços, certa manhã, mas, como a Sra. Ramsay morrera repentinamente na noite anterior, esticou os braços e eles continuaram vazios.)" Ibid., p. 130.
} 
seus filhos Andrew e Prue, ele na guerra e ela no parto, é apresentada de modo bem sumário. A singularidade de criação temporal transcende e diversifica o padrão préestabelecido que caracteriza a primeira parte do romance de Virginia Woolf. Tal forma de construção do tempo remete à ideia de rapidez causada pela velocidade que define o século $\mathrm{XX}$ e todas as consequências funestas resultantes do abandono do homem por si próprio em prol de um mundo mais ágil, mais técnico e tecnológico. A guerra, o ensandecimento das negociações políticas, o massacre de inocentes e a destruição de um grande número de famílias foram os efeitos dos desajustes de um tempo que favoreceu muito mais a evolução tecnológica e a nova realidade política em detrimento dos processos interiores do indivíduo, suas percepções, seu tempo de reencontro consigo próprio e com o outro, ou seja, seu bem estar mental e emocional. O tempo que passa, construído e marcado pelo homem, é o motivador das destruições e da morte, da infelicidade e da separação. Não há momentos para reencontros nessa segunda parte, tudo é escuro e rápido na materialidade execrável do tempo diluidor da felicidade e do conforto pessoal.

Assim, podemos dizer que, em ambos os romances, Woolf se utiliza de uma técnica de construção temporal que privilegia a circularidade e a linearidade, muitas vezes parecendo ajustá-las em oposição, outras, em interação.

No primeiro romance, há o predomínio da circularidade temporal pela fluidez dos pensamentos das personagens, dando, dessa maneira, a impressão de uma fragmentação temporal, de uma presentificação eterna das ações que parece comprometer o próprio enredo da narrativa. A busca pela compreensão da vida e de si própria permite à narradora se inserir num mundo de ilações psicológicas que só poderia ser explicado pelo tempo psicológico. Neste caso, a conexão com o mundo exterior e sua realidade dá-se apenas pela lembrança de um tempo externo, o cronológico, ativado por um relógio histórico londrino que marca, inexoravelmente, o passar da vida de todos. No entanto, este relógio é apenas a 
lembrança da presença de uma realidade factual que parece não interessar em absoluto à protagonista, a não ser pelo viés do pensamento. Não podemos negar que haja certa linearidade temporal em Mrs. Dalloway; no entanto, ela é frágil e fugaz, como se a única forma de construir o tempo fosse por meio dos processos psíquicos e emocionais, com as elucubrações como fio condutor. O resultado disso tudo é um romance que foge aos padrões de fatura ligados à tradição: o predomínio do tempo inexato e circular contextualiza os eventos no presente, causando, dessa maneira, uma fratura na compreensão das relações de anterioridade e posterioridade, o que o romance, de forma geral, não costumava apresentar até então.

No segundo (To the lighthouse), há um maior equilíbrio entre a relação das duas formas de composição do tempo: os fatos da realidade emergem segundo uma estrutura narrativa que ordena os eventos e, consequentemente, os dispõe em uma ordem de sucessão mais clara e perceptível. Isso não significa que o tempo psicológico, circular, não esteja presente e atuante. Ele é, por sua vez, o responsável pelo processo intimista das personagens que liberam seus pensamentos. O fato é que o romance foi construído mediante um equilíbrio entre as duas formas temporais, como já demonstrado. Lucia Miguel Pereira evidenciou esse equilíbrio no ensaio "Dualidade de Virginia Woolf”:

Mrs. Dalloway passa-se num único dia, que, pela sua repercussão interior, como que resume toda uma vida: em To the lighthouse (...) [o tempo] é o tema principal: (...), ele se faz sentir na casa abandonada como se fosse alguma coisa de palpável, uma corrente de ar que levantasse em vez de poeira, fatos esquecidos, que agitasse, em lugar de cortinas, velhas emoções, sonhos antigos (...) ${ }^{27}$.

A opção da escritora inglesa por cristalizar o tempo de forma que fique imperceptível à diferença entre os momentos passados e os presentes foi delineada por ela no ensaio "Modern fiction", quando esboça sua estética ficcional e propõe que a ficção

\footnotetext{
${ }^{27}$ PEREIRA, Lucia Miguel. Escritos da maturidade. Rio de Janeiro: Graphia, 2005. p. 109.
} 
tenha por objetivo expor a vida, uma vez que "life escapes; and perhaps without life nothing is worth while."28 Daí sua escolha em favor dos registros das reflexões das personagens. Nesse aspecto reside a diferença de seu ponto de vista com o de Pereira, que vê o romance como o espaço de representação de uma realidade verossímil, minimamente deformada na transposição para o plano ficcional, com uma construção temporal que pode desencadear a sequência dos eventos formadores da trama.

Para compreender a diferença de abordagem entre Virginia Woolf e Lucia Miguel Pereira com relação à construção do tempo na ficção, R. L. Chambers, em The novels of Virginia Woolf, dá uma pista:

The scene of Mrs. Dalloway was set in London, and in order to write in a "spiritual" way about characters placed in so "materialistic" an environment, a process of abstraction was necessary (...). In To the lighthouse the process of abstraction has, in a sense, been already completed in the plan of the novel before the action starts. The reader now finds himself in a small community of people who might be expected to have "spiritual" interests and experiences, in an environment which might be expected to encourage them. (...) it is easier for the reader to sympathise with and identify with his own experience the lonely questioning of the mind which for Virginia Woolf formed so great a part of life. ${ }^{29}$

Outra diferença apontada por esse mesmo crítico refere-se à estrutura do romance, uma vez que To the lighthouse apresenta uma divisão por capítulos, sugerindo, assim, um sequenciamento temporal bem definido e mudanças de cena, o que não ocorre em Mrs. Dalloway, cujo enredo transcorre numa sequência única, sem divisões, como que representando a fluidez dos pensamentos das personagens que transitam no tempo:

\footnotetext{
28 "A vida escapa e talvez sem ela nada valha a pena.” WOOLF, Virginia. Virginia Woolf-Selected essays. David Bradshaw (Ed.). New York: Oxford University Press, 2008. p. 8. Tradução nossa.

29 "O cenário de Mrs. Dalloway é Londres, e para escrever de um modo "espiritual" sobre personagens colocadas em meio tão "materialista", foi necessário um processo de abstração (...). Em To the lighthouse o processo de abstração, de certo modo, já estava completo no plano do romance antes que a ação se inicie. O leitor agora encontra-se em uma pequena comunidade de pessoas que, espera-se, tenham interesses e experiências "espirituais", em um meio que se supõe que os encoraje. (...) é mais fácil para o leitor compactuar e identificar com sua própria experiência o questionamento solitário da mente que para Virginia Woolf constituía parte tão importante da vida." CHAMBERS, R. L. The novels of Virginia Woolf. London: Oliver \& Boyd Ltd., 1957. p. 32/33/34. Tradução nossa.
} 
[Mrs. Dalloway] (...) is printed from beginning to end as one piece, without parts or chapters or numerical section headings (...) and this is right, for such typographical interruptions would have interfered with the internal unity of the whole. To the lighthouse, on the other hand, marks its change of scene by a numerical heading: the convention is accepted because it is necessary, and because it does not interfere to any important extent with the flow of the "stream of consciousness." 30

Como já dito, a construção do tempo em To the lighthouse também propicia a ordenação cronológica das ações. Lucia Miguel Pereira tem esse tipo de abordagem temporal como princípio estético na produção romanesca, pois, assim, segundo ela, é possível que o texto ficcional se atenha mais à verossimilhança dos acontecimentos narrados. Esse ponto de vista de Pereira é característico de sua visão de romance reforçado pela estética literária dos anos 30 .

Nesse período da nossa literatura a elaboração ficcional enfocava uma construção temporal caracterizada pelo enfoque linear, dado que se coadunava com as necessidades temáticas dessa época, isto é, compor o retrato de um tempo marcado por grandes mudanças sociais e políticas em nosso país.

O tempo nos romances de Pereira se caracteriza pela sequência dos eventos, privilegiando, assim, a construção temporal cronológica (linear) da ficção. Isso não impede a autora de utilizar-se de uma abordagem psicologizante; no entanto, essa abordagem difere da empregada por Woolf, uma vez que, devido à linearidade temporal, o aspecto fragmentário da narrativa é eliminado. Assim, sua elaboração temporal se distingue sobremaneira daquela adotada por Woolf em Mrs. Dalloway, e se aproximará de To the lighthouse, haja vista essa obra apresentar um equilíbrio entre o tempo linear e o psicológico.

30 “[Mrs. Dalloway] (...) é impresso do começo ao fim de uma única vez, sem partes ou capítulos ou cabeçalhos numerados (...) e isso está certo, pois tais interrupções tipográficas teriam interferido com a unidade interna do todo. To the lighthouse, por sua vez, destaca sua mudança de cena por um cabeçalho numerado; a convenção é aceita porque é necessária, e porque não interfere de modo algum com o desenrolar do fluxo de consciência.” Ibid., p. 34-35. Tradução nossa. 
O cenário literário da década de 30 privilegiava a fatura de romances que se preocupavam com as questões sociais e políticas. Muito embora Pereira também estivesse preocupada com essas questões, seu olhar vai se voltar para uma abordagem mais intimista, na qual o pensamento tem um lugar de real destaque. No entanto, este pensamento não é desordenado pelo tempo assim como também não o desordena, da maneira como aparece em Mrs. Dalloway; muito ao contrário, ele deixa transparecer nitidamente a reflexão intimista da personagem ligada às questões sociais de sua época, principalmente as relacionadas com o feminino. Isto tudo é possibilitado pela existência da linearidade temporal que compõe um antes e um depois na narrativa, conferindo ao romance, em sua função básica, uma característica que insere o indivíduo e seus problemas na sociedade, estabelece um contato entre a coisa literária e a pública e permite à literatura se apresentar como uma emoção estética que leva à reflexão cognitiva. Segundo a própria Lucia Miguel Pereira, "a literatura já não é, já não pode ser um passatempo". ${ }^{31}$ Claro que não estamos nos referindo a Mrs. Dalloway como um passatempo ao invés de literatura. Por meio da postura da crítica brasileira, queremos apenas demonstrar a estética de Lucia Miguel Pereira com relação àquilo que ela julga ser efetivamente o papel do romance por meio das interferências da construção temporal no enredo.

De acordo com essas preocupações estéticas Pereira escreve o romance Amanhecer, um texto que trata das questões relativas ao universo feminino, além de contextualizar ideologicamente a situação política do país. Sobre essa particularidade no romance da autora brasileira, Luís Bueno em Uma história do romance de 30, afirma:

No caso do romance de 30, a formação da consciência de que o país é atrasado canalizou todas as forças. Produziram-se romances que se esgotavam ou na reprodução documental de um aspecto injusto da realidade brasileira ou no aprofundamento de uma mentalidade equivocada que contribuiria para a figuração desse atraso. O herói, ao

\footnotetext{
${ }^{31}$ PEREIRA, Lucia Miguel. A leitora e seus personagens. Rio de Janeiro: Grafia, 2005. p. 90.
} 
invés de promover ações para transformar essa realidade negativa, servia para incorporar algum aspecto do atraso. (...) em Amanhecer, [o herói foi] a mulher. ${ }^{32}$

A abordagem romanesca psicológica ou intimista dos anos 30, denominada de "segunda via"33, um termo de Luciana Stegagno Picchio foi pouco discutida pela crítica. No entanto, apresenta-se como uma literatura empenhada, a partir do momento que se volta para as questões sociais do país. Aí está o ponto em que a composição estética de Lucia Miguel Pereira e de Virginia Woolf acerca da circularidade e da linearidade do tempo diverge: para a primeira, o tempo psicológico criado por Woolf destrói a essência da narrativa romanesca pelo predomínio de uma extremada introspecção voltada para os aspectos existenciais da personagem; mesmo quando há uma reflexão sobre as questões sociais, o processo é por demais intimista e existencialista. Com isso, o romance perde a sua característica básica que é a de remeter o indivíduo à sociedade e reproduzir, consequentemente, a realidade social. Para Virginia Woolf, o tempo circular é não mais do que a única solução estética para fazer as personagens se conhecerem por inteiro por meio das ilações do pensamento, não necessariamente ligando-se à realidade externa, ao tempo que passa e marca. Para Woolf, esse tempo cronológico é ameaçador e devastador (como visto na segunda parte de To the lighthouse).

Portanto, o conceito de romance para a escritora inglesa possui uma definição oposta à de Lucia Miguel Pereira. O romance, para Woolf, é o veículo que expressa as interioridades humanas, suas carências, faltas, angústias, conflitos e felicidades por meio das reflexões. Caso haja a necessidade de uma reflexão sobre as questões políticas e sociais, elas devem ser realizadas pelo aparato psicológico das personagens. Em Lucia Miguel Pereira, o romance é de natureza e finalidade social; embora haja intimismo, este não se

\footnotetext{
${ }^{32}$ BUENO, Luís. Uma história do romance de 30. São Paulo: EDUSP/ Campinas: Editora da Unicamp, 2006. p. 78.

${ }^{33}$ Ibid., p. 19.
} 
encontra ligado às elucubrações psíquicas, mas sim a um ordenado questionamento promovido pela inteligência, ou seja, pela racionalidade.

Amanhecer, romance de Lucia Miguel Pereira publicado em 1938, é considerado por Luís Bueno como uma "pequena obra-prima"34. O texto se distingue com relação à grande maioria dos romances de sua época pela abordagem intimista com uso de linearidade temporal, como já ressaltamos anteriormente, e ainda difere dos outros dois romances anteriores de Lucia Miguel Pereira pela utilização do foco narrativo em primeira pessoa.

No texto, a própria protagonista Maria Aparecida narra sua história. Ela é uma menina criada em São José, interior do Rio de Janeiro, de família humilde e, por causa de sua tia freira, foi educada em um colégio religioso. Maria Aparecida é obcecada pela história da Casa Verde, uma mansão vizinha marcada pelo suicídio sem explicação de uma moça. Isso a impressionava, pois, religiosa como era, o suicídio assumia uma dimensão contrária aos princípios sagrados. Sua rotina se altera quando a mansão é alugada para uma família da capital, cuja filha, Sonia, é da mesma idade que Aparecida. Sonia, diferentemente da protagonista, é rica e possui uma visão de vida bem diferenciada dessa última com relação à modernidade. Após o contato com Sonia, as aspirações de Aparecida começam a se modificar, principalmente sobre o casamento. Uma mudança fundamental em sua vida ocorrerá com a chegada de Antônio, um primo de Sonia, vindo do Rio de Janeiro. Ele não é bem visto pela família porque tem ideias diversas: é um comunista envolvido em situações complicadas. Aparecida sente-se fascinada por esse homem a ponto de ter a impressão de que iria determinar seu destino. Além do mais, reconhece nele uma semelhança física com o moço que fora o pivô do suicídio na Casa Verde. Aparecida se apaixona por Antonio, mesmo sabendo que o rapaz é contra o casamento.

\footnotetext{
${ }^{34}$ Ibid., p. 304.
} 
Depois de um tempo em São José, ele retorna à capital. Aparecida alimenta, cada vez mais, o sonho de deixar a cidade onde nascera e, finalmente, o realiza, quando a família de Sonia volta para o Rio de Janeiro. Como a amizade com Sonia havia se intensificado, a protagonista é convidada a ir com eles para a capital, mediante a promessa de emprego que o pai da amiga havia lhe feito. Sonia havia sido violentada em São José e, ao retornar ao Rio, decide tornar-se freira. Aparecida, por sua vez, reencontra Antônio e resolve morar com ele, mesmo sabendo que não haveria casamento. Essa situação a faz refletir sobre uma eterna espera por uma mudança em sua vida e, também, se perguntar se aquele seria seu verdadeiro destino.

Maria Aparecida anseia por uma mudança de situação como indivíduo e ser social, na medida em que questiona o "destino natural" do casamento e ambiciona uma ascensão social, ou seja, Pereira evidencia a possibilidade da emancipação feminina em uma sociedade patriarcal. Assim que o tempo vai transcorrendo e o enredo muda de uma situação para outra, a posição de Maria Aparecida, tanto como indivíduo quanto como um ser social, também vai mudando. O desenrolar do enredo está intimamente ligado às transformações da protagonista ao longo da temporalidade construída para o romance. Contrariamente, em Mrs. Dalloway, as personagens não evoluem com o tempo, pois estão eternamente presentificadas na circularidade do psiquismo.

Em Amanhecer, podemos estabelecer uma relação entre a inquietação da personagem com as circunstâncias sociais nas quais o romance foi elaborado. No ano anterior à publicação da obra, foi estabelecida, por Getulio Vargas, a lei da censura em nome dos bons costumes. O romance de Pereira se situa na direção oposta ao propor uma mudança na concepção da ideia de feminino. Está aí a interferência da realidade externa na composição estética de Lucia Miguel Pereira e a vinculação da literatura às questões 
públicas, o que demonstra como a arte é um dos gatilhos deflagradores das reflexões críticas acerca da sociedade, seus costumes e regras.

O tom lírico que perpassa o romance em forma de pensamentos, sensações e sonhos caracteriza o narrador-personagem que se entrega ao relato dos fatos acontecidos num período de dois anos, possibilitando ao leitor refletir sobre as questões apresentadas pela protagonista: virgindade, casamento, independência, religião, relacionamentos, liberdade feminina, a sociedade burguesa, entre outros temas. O modo de exprimir suas recordações dá ao texto um tom confessional, porém motivador de reflexões críticas, em que o presente passa a ser uma consequência do passado no desencadear dos eventos que compõem o enredo da narrativa. Essa característica do romance de Pereira é salientada por Marlene Bilenky, que alude ao crítico literário Flávio Loureiro Chaves e reforça a ligação entre a escritora brasileira e seu tempo:

A década de 30 traz a marca da confissão e do memorialismo que serve como testemunho e depoimento do que era o Brasil e como estava sendo, projeto de rever o país, cujo "drama individual se revela como representação e metáfora do desastre social." 35

A subjetividade desse narrador é estabelecida ou pela aproximação no passado com a coisa narrada, ou pela sua distância quando a descreve. Porém, paradoxalmente, esse lirismo permite que a individualidade característica de um texto como o de Pereira remeta ao social, na medida em que Aparecida funciona como uma metonímia para denunciar uma sociedade. Da mesma forma que Pereira ressalta que é preciso registrar as angústias e anseios da protagonista, também revela a necessidade da vida social como pressuposto da condição humana. A temporalidade em Amanhecer extrapola o sentido primeiro de uma

\footnotetext{
35 BILENKY, Marlene. O claro olhar (Análise da personagem feminina na ficção de Lúcia Miguel Pereira). Dissertação de Mestrado. Universidade de São Paulo, São Paulo, 1986. p. 176.
} 
mera volta ao passado e adquire, em última instância, um caráter humanístico, como ocorre nos textos de Virginia Woolf, qualidade essencial no romance, segundo Pereira.

O tempo apresentado no momento da fala da protagonista relata a sucessão dos fatos do passado que contribuem para novas situações no futuro. Cabe lembrar que a Sra. Ramsay, em To the lighthouse, também antecipa os acontecimentos futuros, porém, não o faz por meio do encadeamento dos fatos lógicos, mas pelo presságio que sente em relação à própria morte. Maria Aparecida, por sua vez, conclui os acontecimentos futuros pela esperança justificada por uma lógica decorrente da evolução dos fatos:

Lembro-me tão bem daquele dia... Papai chegou em casa, e (...) disse (...) - Chegou a família que alugou a Casa Verde. (...) Fiquei escutando o barulho da chuva e imaginando (...). Uma menina loura, alta, com quem eu passearia de braço dado na estação (...). Ela me diria: - Como é que, bonita como você é, pode viver neste buraco? (...) E depois apareceria o seu irmão, que se apaixonaria por mim; e eu me casaria, e iria morar no Rio, numa casa cheia de cortinas e tapetes. ${ }^{36}$

Pereira, em vários ensaios de Prosa de ficção, reporta-se à necessidade de o romance expressar o meio que o circunda a fim de recriar uma realidade ficcional muito próxima da vida real. Entendemos que este pressuposto da escritora brasileira tem muito a ver com as características da estética de seu tempo. O romance de 30 procurou a verossimilhança como recurso fundamental para solucionar os seus objetivos, de maneira que a forma do romance pudesse dar ao conteúdo a sua validade. Porém, Pereira destaca-se por apresentar a sociedade na qual vivia de um modo diferenciado ao abordar os conflitos internos das personagens, mais preocupada com o enfoque humanista. No ensaio "Aventuras sobrenaturais no romance de Bernanos", publicado no Boletim de Ariel em 1936, ela esclarece que “(...) o romance é a vida - e percorre, como a existência, toda a gama do fútil ao trágico, e muitas vezes consegue nos mostrar, condensada por um

\footnotetext{
${ }^{36}$ PEREIRA, Lucia Miguel. Amanhecer. Rio de Janeiro: Livraria José Olympio, 1938. p. 5-6.
} 
temperamento de artista, essa verdade profunda do homem que o quotidiano dilui de ordinário."37 Tal afirmação explica o uso da linearidade temporal, tão defendida por ela, não como um gosto pessoal ou uma regra imposta, mas sim como uma forma de organização temporal mais adequada às finalidades do romance.

Sua estruturação estética, principalmente com relação à temporalidade e sua ligação com a recriação da realidade no plano ficcional, deixa claro a que o romance se propõe: trazer para o mundo da literatura uma fusão entre a emoção e a racionalidade de forma a integrar a arte ao pensamento crítico social. Indubitavelmente, o romance não poderia deixar de ser o nicho da verossimilhança caracterizada pela história do indivíduo e seu meio histórico-social. Não queremos dizer com isso que o romance Amanhecer seja um documento histórico-sociológico de natureza científica, ao contrário, é um espaço literárioartístico no qual e pelo qual as reflexões sobre os problemas sociais e as angústias individuais pendem para o lado humano, uma preocupação artística com o outro e com a sociedade de maneira geral. Das páginas carregadas de pensamentos intimistas que povoam o texto de Lucia Miguel Pereira brotam as ramificações discursivas que motivam o leitor a uma análise dos fatos humanos, sociais e políticos.

Antonio Candido comenta o período literário de 30 em nossa história e a postura da intelectualidade com relação a um Estado autoritário de forma a elucidar as questões ideológicas subjacentes à elaboração artística. No ensaio "A revolução de 1930 e a cultura" diz que, na década de 30:

(...) houve maior consciência a respeito das contradições da própria sociedade, podendo-se dizer que sob este aspecto os anos 30 abrem a fase moderna nas concepções de cultura no Brasil. ${ }^{38}$

Deve-se reiterar que Lucia Miguel Pereira articulou e defendeu uma estética de criação temporal para o romance que realmente fez jus aos propósitos do gênero. Por essa

\footnotetext{
${ }^{37}$ PEREIRA, Lucia Miguel. A escritora e seus personagens. Rio de Janeiro: Grafia, 2005. p, 145.

${ }^{38}$ CANDIDO, Antonio. A educação pela noite e outros ensaios. São Paulo: Ed. Ática, 2000. p. 195.
} 
razão, em contato com o romance Mrs. Dalloway, a escritora brasileira apresenta resistências à temporalidade eternamente presentificada e o excesso de interiorização das personagens expresso pelo pensamento que volteia e revolteia, nunca avança no tempo e não recolhe do mundo externo a materialidade suficiente para pôr em contato a coisa literária com a pública. Tudo é pessoal, excessivamente pessoal em Mrs. Dalloway, tudo flui para dentro e lá fica estagnado, ao passo que, em Amanhecer, o pensamento escorre para fora, contagia e invade o leitor convidando-o a participar da obra. Assim, o texto de Pereira se abre para o humano e para a sociedade, transcende o intimismo e a subjetividade exacerbada para tocar nos conflitos comuns a todas as pessoas. O enredo poderia, em suma, ser a historia de cada um de nós. O relato claro e compreensível, repleto de agilidade, traz em sua construção um tempo que passa como qualquer outro e marca um período da vida como qualquer tempo sobre o qual se possa refletir sem a necessidade de isolamento.

Outra abordagem de Amanhecer reporta-se à obra como um romance de formação, o Bildungsroman, no qual as mudanças pelas quais a personagem passa fazem parte de um processo de amadurecimento. Aparecida, então, é uma típica personagem dessa espécie de romance e tem Antonio como seu mentor, ou seja, aquele que propicia a transformação. A protagonista evolui com o passar do tempo, suas percepções e reflexões estão em constante alteração como se avolumasse, crescesse, a partir de um ponto mínimo para uma conformação mais adulta. Muito embora os pensamentos continuem a agitar seu psiquismo, não há paradas ou retrocessos; o que existe, na verdade, é um moto-contínuo que permite à personagem se movimentar para um ponto maior de formação. O tempo não a escraviza, muito pelo contrário, a liberta das posições menores para ganhar estatura como um ser psíquico, espiritual e carnal; um ser real que vive uma realidade imediata e intensa, indispensável para o seu crescimento. Se em To the lighthouse o tempo que evolui é algoz e devastador, em Amanhecer, a sua linearidade é construtora, propícia e benéfica no sentido 
de formar a vida. Partindo-se da Casa Verde, que é o ponto da morte para Maria Aparecida, o tempo se estende levando-a para a vida. Em To the lighthouse, o passar do tempo deseduca, isto é, demonstra claramente que o que é civilizado pode ser destruído pelo conflito armado, pelo inconciliável. Qualquer sentido de formação é violentamente amputado pela passagem do tempo. Contrariamente, no romance de Pereira, a evolução do tempo educa para a vida e forma o elemento humano, ou seja, possui uma "função didática”39 ${ }^{, 3}$ como afirma Cristina Ferreira Pinto.

Além dessa leitura, o romance de Pereira propõe igualmente uma aproximação com a obra de Proust, no sentido de, assim como o escritor francês, também apresentar reminiscências e ainda retratar a sociedade de seu tempo. Dessa forma, há predominância da utilização da primeira pessoa de modo a conceber o enredo a partir de uma experiência íntima trazida ao presente. Enquanto o narrador de No Caminho de Swann "recordava, para cada quarto, o tipo de cama, o local das portas", ${ }^{40}$ no começo de Amanhecer, Aparecida afirma: "Lembro-me tão bem daquele dia..."41.

Nesse contexto, o narrador proustiano resgata o passado por meio da memória afetiva, um tempo do qual foi apartado, para viver, no presente, um real que não o satisfaz. No entanto, não se trata de reviver o passado como se fosse o presente ou realimentá-lo para que ganhe formas e contornos de utopia ou saudosismo. Trata-se, então, de uma busca arqueológica para que o passado sustente a conformação do presente. Não há psicologismos exagerados e crises existenciais conflituosas; o que há, na verdade, é uma tentativa de apreender o real do momento pela essência dos acontecimentos que formaram a vida da personagem ao longo do tempo para que a existência possa ser alicerçada pelo viés de uma história pessoal, íntima e significativa. Walter Benjamim, em "A imagem de Proust",

\footnotetext{
${ }^{39}$ PINTO, Cristina Ferreira. O bildungsroman feminino: quatro exemplos brasileiros. São Paulo: Ed. Perspectiva, 1990. p. 60.

${ }^{40}$ PROUST, Marcel. No caminho de Swann. Tradução Fernando Py. Rio de Janeiro: O Globo; São Paulo: Folha de São Paulo, 2003. p.12.

${ }^{41}$ PEREIRA, Lucia Miguel. Amanhecer. Rio de Janeiro: José Olympio, 1938. p. 5.
} 
afirma sobre esse assunto que "o importante para o autor que rememora, não é o que ele viveu, mas o tecido de sua rememoração, o trabalho de Penélope da reminiscência." ${ }^{42}$

Em Amanhecer, Aparecida, ao lembrar-se de seu passado, tenta recuperar as boas recordações de sua família, as ideias inovadoras de Sonia e, claro, dos momentos com Antonio. Apesar da semelhança com Proust, difere dele pela técnica de narração, uma vez que o escritor francês faz algumas inserções abruptas que expressam os pensamentos da personagem quando se encontra no momento de suas recordações: "Depois renascia a lembrança de uma nova atitude; a parede fugia em outra direção: eu estava em meu quarto na casa de Mme. de Saint - Loup, no campo; meu Deus! São pelo menos dez horas, já devem ter acabado de jantar!"43

Já Pereira, além do uso da primeira pessoa, vale-se do discurso direto em suas recordações, como ocorre ao lembrar-se de Sonia: "E perguntei, achando que isso talvez me prestigiasse junto da minha nova amiga: - Você não conhece o meu tio, o coronel Antonio Lobato?"44

Tanto Pereira quanto Proust empregam a memória involuntária em seus processos de rememorações, ou seja, a lembrança surge como resultado de uma emoção ou sensação. Esse termo é originário da teoria de Bergson, segundo a qual existem duas formas de recuperar o passado, como assinala Flávio Pereira Camargo, em "Marcel Proust e o triunfo da memória":

(...) há duas formas de sobrevivência do passado: 1) em mecanismos motores e 2) em lembranças independentes. A memória voluntária é aquela adquirida pelo hábito, pela repetição de um mesmo esforço, de uma mesma ação (...) a memória involuntária (...) surge de uma lembrança e é imprevisível. Há como que uma amplificação de um ponto do passado. É o resultado de uma emoção, de uma sensação $(\ldots)^{45}$.

\footnotetext{
${ }^{42}$ BENJAMIN, Walter. Magia, técnica, arte e política: ensaios sobre literatura e história da cultura. Trad. de Sérgio Paulo Rouanet. São Paulo: Brasiliense, 1994. p. 37.

${ }^{43}$ PROUST, Marcel . op. cit., p.12.

${ }^{44}$ PEREIRA, Lucia Miguel. Amanhecer. Rio de Janeiro: Livraria José Olympio, 1938. p. 18.

${ }^{45}$ CAMARGO, Flávio Pereira. Disponível em: <http:// www.ucm.es/info/especulo/numero 41/proustme.html.>. Acesso em: 07 nov. 2011.
} 
Outra relação entre a escritora e Proust pode ser depreendida a partir de Mimesis, de Auerbach, em que o autor se refere à técnica utilizada pelo escritor francês. Nesse texto ele pontua que "Proust visa à objetividade e à essência do acontecido: procura atingir esta meta confiando-se à direção da sua própria consciência, não da consciência presente em cada instante, mas da consciência rememorante." 46

Com relação a Virginia Woolf, observamos em alguns trechos de To the lighthouse esse mesmo tipo de recordação, ao passo que, em Mrs. Dalloway, ela é totalmente ausente. Na realidade, no segundo romance, percebe-se outro conceito de Bergson: a "durée", isto é, a expansão da profusão psicológica das personagens, em que cabe " toda vida em um dia [e] toda vida em um momento." ${ }^{47}$ Ou seja, como diz o próprio filósofo:

Ela [a duração] é memória, mas não memória pessoal (...) é uma memória (...) que prolonga o antes no depois (...) a transição ininterrupta, multiplicidade sem divisibilidade e sucessão sem separação, para encontrar por fim o tempo fundamental. ${ }^{48}$

Esse aspecto temporal proposto Bergson é motivo de muita controvérsia sobre sua utilização tanto por Proust quanto por Virginia Woolf. Para alguns estudiosos, como os filósofos Paul Ricoeur (1913- 2005) e Gilles Deleuze (1925-1995), o escritor francês não se alinhava ao conceito de "duração" proposto por Bergson. No ensaio "Acordes e dissonâncias entre Bergson e Proust", Regina Rossetti, ao propor a discussão sobre a relação entre os dois, comenta:

Para Ricoeur, o tempo de Proust é um tempo que nos engloba, onde todos os homens têm o seu lugar, lugar mais considerável que o lugar

\footnotetext{
${ }^{46}$ AUERBACH, Erich. Mimesis - A representação da realidade na literatura ocidental. (Coleção Estudos dirigida por J. Guinsburg). São Paulo: Perspectiva, 2002. p. 488.

${ }^{47}$ MENDILLOW, A. A. O tempo na literatura. Tradução Flávio Wolf. Porto Alegre: Ed. Globo, 1972. p. 167.

${ }^{48}$ BERGSON, Henri. Duração e simultaneidade. São Paulo: Martins Fontes, 2006. p. 51-52.
} 
que ocupam no espaço, mas, mesmo assim, lugar. Sendo assim, o tempo em Proust se aproximaria mais do tempo espacializado do que da duração bergsoniana. ${ }^{49}$

Por outro lado, Estela Sahm afirma:

(...) no que diz respeito à duração bergsoniana, trata-se de um movimento contínuo e ininterrupto que é próprio a nossa existência na dimensão temporal; o que é reproduzido, na criação literária de Proust, é um possível fluxo de pensamento, com toda a variedade que o constitui; assim, não encontramos aqui uma diferença de concepções, mas apenas constatamos que essa multiplicidade diz respeito ao próprio fluxo de pensamento, e não se opõe, dessa forma, à continuidade da duração. ${ }^{50}$

Com relação à existência ou não desse "fluxo de pensamento" na obra do escritor

francês, Robert Humphrey assinala:

Marcel Proust escreveu um clássico moderno muitas vezes citado como exemplo da ficção do fluxo da consciência, mas À la recherche du temps perdu (Em busca do tempo perdido) somente se ocupa com o aspecto rememorativo da consciência. Proust estava propositalmente recapturando o passado com finalidades de comunicação; portanto não escreveu um romance de fluxo da consciência. ${ }^{51}$

No caso de Woolf, Kumar registra a respeito desse asunto que "her [Woolf's] work provides (...) another example of parallelism between the stream of consciousness technique and the Bergsonian flux."52 Ele ainda salienta suas características como escritora: "Virginia Woolf was an exceptionally individualistic writer who had (...) formulated her own theories regarding the nature of reality and experience. The true

\footnotetext{
${ }^{49}$ ROSSETTI, Regina. "Acordes e dissonâncias entre Bergson e Proust". Disponível em: <http://www.revistafilosofia.unisinos.br>. Acesso em: 08 nov. 2011.

${ }^{50}$ SAHN, Estela. Bergson e Proust- Sobre a representação da passagem do tempo. São Paulo: Iluminuras, 2011. p. 73-74.

${ }^{51}$ HUMPHREY, Robert. O fluxo de consciência. Tradução Gert Meyer. São Paulo: McGraw-Hill, 1976. p. 3-4.

52 "sua [de Woolf] obra possibilita (...) um outro exemplo de paralelismo entre a técnica do fluxo de consciência e o fluxo bergsoniano." KUMAR, Shiv K. Bergson and the stream of consciouness novel. New York: New York University Press, 1963. p. 64. Tradução nossa.
} 
explanation of the Bergsonian character of her novels lies in her being a manifestation (...) of the Zeitgist." ${ }^{, 53}$

É grande a polêmica instaurada em torno de Proust e Woolf sobre o uso da "durée". Essa controvérsia é aumentada pelo fato de não haver comprovação do contato direto entre a escritora e o filósofo francês, mas apenas indireto, pela evidência de sua leitura dos textos de Proust. De qualquer forma, ao lermos as obras dos dois escritores percebemos que a escritora inglesa aproxima-se mais desse conceito bergsoniano, como no caso de seu livro The waves, citado no capítulo anterior.

A partir das considerações que fizemos acerca dos romances de Virginia Woolf e Lucia Miguel Pereira, podemos estabelecer alguns pontos em comum e algumas diferenças sobre a recriação do tempo no romance.

Em Mrs. Dalloway, o que predomina é a fragmentação temporal, de forma que os pensamentos das personagens vão delineando o romance. Essa característica é tão marcante que torna o enredo, entendido como uma sucessão de fatos, praticamente inexistente.

Woolf, no ensaio "Modern fiction”, estabelece seus parâmetros para a escrita ficcional, cujo objetivo, segundo ela, é aproximar-se o mais perto possível da realidade, e, para tanto, retratar os pensamentos das personagens: "Let us record the atoms as they fall upon the mind in the order in which they fall, let us trace the pattern, however disconnected and incoherent in appearance, which each sight or incident scores upon the consciousness." 54

Já no texto de Pereira, apesar de centrar-se nos conflitos internos da personagem, o tempo rememorado é bem delineado, de maneira a situar o leitor na ocasião em que os fatos

\footnotetext{
53 "Virginia Woolf foi uma escritora excepcionalmente individualista que (...) formulou suas próprias teorias sobre a natureza da realidade e da experiência. A verdadeira explicação do caráter bergsoniano de seus romances reside em ela ser uma manifestação (...) do Zeitgeist. [espírito do tempo]”. Ibid., p. 68. Tradução nossa.

54 "Recordemos os átomos que se lançam sobre a mente e a ordem em que caem, vamos estabelecer o desenho que cada visão ou incidente imprime na consciência, por mais desconexo e incoerente que seja na aparência.” WOOLF, Virginia. Virginia Woolf-Selected essays. David Bradshaw (Ed.). New York: Oxford University Press, 2008. p. 9. Tradução nossa.
} 
ocorreram. Pereira, tal como Woolf, partiu do princípio da necessidade de retratar a personagem por inteiro, o que implica uma abordagem mais interiorizada. Porém, diferentemente de Pereira, a autora inglesa opta por um maior aprofundamento do psiquismo das personagens do que aquele observado em Aparecida.

Em To the lighthouse, a passagem do tempo é mais demarcada que em Mrs. Dalloway. A própria divisão do romance em três partes já denota um cuidado em estabelecer períodos específicos de tempo para o desenrolar das ações, além de uma atenção voltada para aspectos do cotidiano. Uma passagem do texto sobre a Sra. Ramsay exemplifica a união entre os aspectos psicológicos da personagem com seu dia-a-dia:

like a ghostly roll of drums remorselessly beat the measure of life, made one think of the destruction of the island and its engulfment in the sea, and warned her whose day had slipped past in one quick doing after another that it was all ephemeral as a rainbow. ${ }^{55}$

Pereira, ao descrever as recordações de Aparecida, apresenta um tempo bem delimitado, sugerindo, assim, uma ordem cronológica dos fatos. A estrutura de seu romance, dividido em capítulos, corrobora sua opção por uma temporalidade encadeada sequencialmente. Um excerto, que se refere à protagonista, exemplifica essa proposta da autora:

O mundo de Sonia me aparecia como uma feira, como o parque de diversões que vi no Rio, quando lá estivera havia dois anos, logo que saí do colégio, para consultar um médico. O da morta era como a Casa Verde- a Casa Verde de antes da chegada de Sonia - misterioso, vasio [sic] aparentemente, cheio de emoção. ${ }^{56}$

Portanto, To the lighthouse aproxima-se mais de sua estética ficcional, calcada em uma abordagem que visa à verossimilhança por meio da construção do tempo ficcional, do

\footnotetext{
55 “(...) como o rufar fantasmagórico de tambores que batessem impiedosamente o sentido da vida, fazia pensar na destruição da ilha e no seu engolfamento com o mar e a prevenia (a ela cujo dia escapara com um afazer depois do outro) de que tudo era efêmero como um arco íris." WOOLF, Virginia. Passeio ao farol. Tradução Luiza Lobo. Rio de Janeiro: Ed. Rio Gráfica, 1987. p. 20-21.

${ }^{56}$ PEREIRA, Lucia Miguel. Amanhecer. Rio de Janeiro: Livraria José Olympio, 1938. p. 42.
} 
que Mrs. Dalloway, o que faz a escritora brasileira considerá-lo um texto cuja falta de clareza - causada pela fragmentação temporal desencadeada pelo excesso de psicologismo dificulta a inteligibilidade.

Pela comparação entre os romances de Virginia Woolf e Lucia Miguel Pereira notamos que suas estéticas se diferenciam no modo da apresentação do tempo ficcional, que, por sua vez, diferencia o modo de concepção das personagens e do enredo. $\mathrm{Na}$ elaboração romanesca da escritora inglesa há o predomínio do tempo psicológico sobre o cronológico, o que permite um maior aprofundamento na interioridade das personagens e deixa a trama em um segundo plano.

Já Pereira busca um equilíbrio entre a realidade e a interioridade das personagens, a partir de um romance em que a temporalidade seja mais linear, de forma a não comprometer a inteligibilidade da trama.

Porém, as autoras se aproximam em suas temáticas de cunho humanístico, ao abordar questões existenciais e ao perscrutar questões intimamente relacionadas à essência da mulher, com um lirismo que aproxima suas obras ficcionais da poesia.

Dessa forma, é questionável afirmamos peremptoriamente que haja uma total dissensão entre seus conceitos estéticos, pois, em seu âmago, seus romances nos propiciam a reflexão sobre a natureza humana. Haverá outro assunto mais importante de que trate a literatura? 
CAPÍTULO IV - O ENSAIO COMO ESPAÇO DE CRIAÇÃO ARTÍSTICA 
“Crítica e feminismo", publicado no Correio da Manhã em 1944, é um olhar minucioso por meio do qual Lucia Miguel Pereira contempla dois volumes da ensaística de Virginia Woolf, The common reader (1925) e A room of one's own (1929), mediante o foco de análise estético, que examina como Woolf constrói seus ensaios pelo ajustamento da crítica à criação literária.

Lucia Miguel Pereira enfatiza que os aspectos estéticos estabelecem diferenças substanciais entre os ensaios da escritora inglesa com relação aos seus contemporâneos e predecessores.

Em The common reader, Pereira assinala um novo estilo de escrita ensaística pela inovação da linguagem, a qual observa ser uma união entre a da forma narrativa, típica das histórias ficcionais, e a da crítica, que se caracteriza por um texto objetivo e de natureza analítica. A confluência dessas duas linguagens praticamente antagônicas consolida um novo parâmetro para a concepção do ensaio que acaba por fugir aos padrões acadêmicos vigentes até então. O texto crítico passa a ser um local de encontros e inclusões, de possibilidades de coexistência entre aquilo que era, até Virginia Woolf, aparentemente inconciliável. A fusão da linguagem narrativa com a reflexiva cria uma nova espécie de textura que desloca o ensaio do âmbito puramente científico, didático e informativo, o que doravante chamaremos de ensaio crítico, para reposicioná-lo como um objeto artístico, cuja elaboração formal seja capaz de atrair a atenção do leitor ao romper com seu horizonte de expectativas e possibilitar, dessa maneira, a fruição estética que apenas as obras de arte são capazes de proporcionar.

Ao mesmo tempo em que surpreende pela beleza da inovação da linguagem capaz de recriar a forma, o ensaio de Woolf, observa Pereira, expressa opiniões pessoais da autora por meio de uma fundamentação sólida e bem articulada, revela análises 
literárias muito apuradas e, acima de tudo, desperta no leitor a motivação e o prazer em ler aquilo que está sendo analisado, além de desafiá-lo a refletir sobre os temas ali contemplados, de forma que a sensibilidade e a inteligência do leitor sejam frequentemente reclamadas. Este leitor, então, é convidado a participar daquele universo instigante e prazeroso e, assim, ser incluído numa relação humana com a autora.

O ensaio, com Woolf, sai de sua concha hermética e assume um novo papel: o de veículo das interações humanas, o instrumento da preocupação com a importância do "outro", o espaço de encontros prazerosos.

A room of one's own, por sua vez, é a coletânea de ensaios na qual Lucia Miguel Pereira descobre uma excessiva presença feminina de Virginia Woolf em toda sua essência conflitiva, quer seja pessoal, psicológica e social-ideológica, quer seja como escritora. É desse espaço metalinguístico que a crítica brasileira extrai leituras reveladoras e instigantes acerca das condições existenciais de Virginia Woolf, enquanto esta explica seu processo de criação literária em relação à composição estética do texto e às condições ideais para a produção de literatura em sua época.

As questões sobre o feminismo como um movimento social e humano em conflito e confusão com a "fragilidade sofisticadamente feminina" e sua reprimida "consciência de sexo" são aqui abordadas. As relações de Woolf com o masculino, que vão desembocar na androginia como explicação metalinguística para a criação literária, são, nesse momento, fortemente questionadas por Pereira: o protótipo do andrógino, que para Virginia Woolf é o cerne da criação, para Lucia Miguel Pereira é apenas uma confusão intelecto-pessoal da escritora inglesa, uma maneira de desabafar seu

\footnotetext{
${ }^{1}$ PEREIRA, Lucia Miguel Pereira. Escritos da maturidade. Rio de Janeiro: Grafia, 2005. p. 114.Ibid., p.114.
} 
ressentimento e amargor contra os homens e de denunciar seu sentimento de inferioridade como mulher.

Para Lucia Miguel Pereira, nos ensaios de $A$ room of one's own, que são uma análise das relações da mulher com o romance, o que mais aflora é Virginia Woolf como ser humano, ou seja, mais do que estética ou crítica literária em geral, o que emerge da profundidade desses textos é uma autora in persona em todos os seus aspectos existenciais, angustiantes, confusos e conflitivos.

Para acompanhar e expor a leitura de Lucia Miguel Pereira, principalmente acerca das inovações observadas em The common reader, serão revisitadas breve e panoramicamente as informações básicas sobre o ensaio moderno desde Montaigne, além de examinada a forma do ensaio na Inglaterra até o momento dos escritos de Woolf e seus contemporâneos, entre os quais selecionamos Matthew Arnold, T. S. Eliot e o casal Leavis, em virtude de suas relevâncias, contribuições e importâncias na construção do ensaio moderno inglês.

É esta rápida incursão pela história do ensaio e, consequentemente, da leitura de obras literárias e das relações autor-obra-leitor, que levará à compreensão do ponto-devista de Lucia Miguel Pereira acerca das inovações na ensaística de Woolf.

O ensaio moderno foi introduzido por Montaigne em 1588 e tem como finalidade a apresentação da expressão dos pensamentos pessoais acerca de um tema sob a forma de uma escrita subjetiva e livre. Na realidade, desde sua origem até os dias de hoje, trata-se de um gênero literário sobre o qual é particularmente difícil estabelecer uma rigorosa definição. Sobre a sua elaboração, Montaigne afirma: 
Minhas concepções e meus pensamentos só avançam às apalpadelas, cambaleantes, a escorregar entre tropeços; e por mais longe que vá, não fico satisfeito; vejo terras ainda além, mas turvas e enevoadas e não as posso distinguir. (...) Exponho aqui meus sentimentos e opiniões, dou-os como concebo e não como os concebem os outros; meu único objetivo é analisar a mim mesmo e o resultado dessa análise pode, amanhã, ser bem diferente do de hoje, se novas experiências me mudarem. Não tenho autoridade para impor minha maneira de ver, nem o desejo, sabendo-me mal instruído para instruir os outros. ${ }^{2}$

Em seu ensaio "Montaigne", coligido em The common reader, Woolf enfatiza as definições do autor francês com relação ao ensaio como um espaço de expressão pessoal, de errâncias e divagações: “(...) talking of oneself, following one’s own vagaries, giving the whole map, weight, colour, and circumference of the soul in its confusion, its variety, its imperfection-this art belonged to one man only: Montaigne."3 A fim de descartar qualquer aspecto científico ou dogmático e realçar a importância da subjetividade como fonte das opiniões e dos juízos, ela escreve em "The decay of essaywriting":

The peculiar form of an essay implies a peculiar substance; you can say in this shape what you cannot with equal fitness say in any other. (...). Almost all essays begin with a capital I - 'I think', 'I feel' - and when you have said that, it is clear that you are not writing history or philosophy or biography $(. . .)^{4}$.

Tal concepção se opõe radicalmente à visão cientificista e empírica do século XIX que a precedeu e ainda irradiava as suas luzes em direção ao século XX. Nesse período,

\footnotetext{
${ }^{2}$ MONTAIGNE, apud Galvão, Sylvia C. Abbot. O gênero como ensaio: momentos de diálogos/confronto e murmúrio subjetivo. Revista Vivência, $\mathrm{n}^{\circ}$ 31. UFRN, 2006. p. 9-15.

3 “'(...) conversa sobre si mesmo, seguindo suas próprias excentricidades, fornecendo todo mapa, peso, cor e circunferência da alma em sua confusão, variedade, imperfeição - esta arte pertenceu somente a um homem: Montaigne." WOOLF, Virginia. The common reader. New York: Harvest/Harcourt, 1984. p. 58. Tradução nossa.

4 "A forma característica do ensaio sugere um material característico; você pode expressar nessa forma o que não pode com a mesma adequação em qualquer outra (...). Quase todos os ensaios começam com a maiúscula Eu - 'Eu acho', 'Eu sinto'- e quando você diz aquilo, está claro que você não está escrevendo história ou filosofia ou biografia (...)".WOOLF, Virginia. Virginia Woolf-Selected essays. David Bradshaw (Ed.). New York: Oxford University Press, 2008. p. 4. Tradução nossa.
} 
o empirismo se manifestou por meio do Positivismo, o qual enunciava a aplicação dos rígidos princípios e métodos das ciências a fim de solucionar os problemas do mundo e da vida. Havia, ainda, o fenomenalismo - tudo aquilo que sabemos sobre o mundo externo só pode ser aceito se comprovado por meio da experiência, e todo fato enunciado tem obrigatoriamente de ser provado pelas ferramentas e pela linguagem da ciência. Nenhuma enunciação acadêmica deveria, portanto, escapar das rígidas imposições formais estabelecidas pelas normas científicas. Isso levava, naturalmente, a uma ostensiva impessoalidade e severa padronização na elaboração de um texto científico.

Com relação à história da crítica literária inglesa, podemos dizer que teve seu começo, efetivamente, no século XVI, pois antes dessa data não há registros significativos, como afirma George Saintsbury na obra A history of English criticism:

Until the close of the fifteenth century, and for some decades afterwards, not a single critical treatise on English existed in the English language, or even in Latin; the nearest approach, even in fragment, to any utterance of the kind being the naif and interesting, but only infinitely critical $(\ldots)^{5}$.

Na época elisabetana (1558-1603), que corresponde ao renascimento inglês, houve a revalorização dos estudos sobre os clássicos, com predomínio de uma linguagem retórica na crítica. Sobre essa circunstância, Saintsbury nos informa que: “(...) all (the critics) were fully penetrated with the Renaissance adoration of the classics; and this was lucky again, because the classics alone could supply the training

\footnotetext{
5 “Até o término do século quinze, e por algumas décadas seguintes, nem um simples tratado crítico foi registrado em língua inglesa, ou mesmo em latim; o que mais se aproximava, mesmo em fragmento, a qualquer expressão do tipo, era tido como ingênuo e interessante, mas apenas infinitamente crítico." SAINTSBURY, George. A history of English criticism. New Delhi: Atlantic, 2004. p. 28. Tradução nossa.
} 
and the models just then required by English prose, and even to some extent by English poetry"6.

Cumpre destacar que, nesse período, durante o qual a crítica começa a se manifestar na Inglaterra, Ben Jonson foi considerado "the greatest of Elizabethan critics, and perhaps the only English critic who deserves the adjective "great" before Dryden."” Com um conhecimento literário vasto e sólido, foi o primeiro a introduzir o conceito de regra na condução de sua crítica. Embora seguisse rigidamente o classicismo, ele não se opunha à liberdade dos poetas e considerava os clássicos mais como uma orientação do que como uma norma a ser obedecida. Sobre as regras literárias, já no prólogo de sua comédia Volpone (1606), ele afirma que segue as leis de uma comédia refinada:

As best critics have designed;

The laws of time, place, persons he observeth From no needful rule he swerveth (sic) ${ }^{8}$

Sua obra principal de crítica literária é Timber or discoveries, publicada postumamente em 1641. Nela, advoga os princípios norteadores da estruturação de um texto:

De stylo, et optimo scribendi genere. - For a man to write well, there are required three necessaries- to read the best authors, observe the best speakers and much and after exercise of his own style; in style to consider what ought to be written, and after what manner. He must first think and excogitate his matter, then choose his words, and examine the weight of either. Then take care, in placing and ranking

\footnotetext{
6 “(...) todos (os críticos) estavam totalmente habituados à adoração dos clássicos da Renascença; e isso foi muita sorte (...) porque só os clássicos podiam suprir o aprendizado e os modelos só então exigidos pela prosa inglesa, e ainda de certa forma pela poesia inglesa.”. Ibid., p. 30-31. Tradução nossa.

7 "O mais importante crítico elisabetano e talvez o único crítico inglês que mereça o adjetivo 'importante' antes de Dryden.”. Ibid., p. 70. Tradução nossa.

8 "Como os melhores críticos conceberam/ As leis do tempo, lugar e pessoas ele observa/ De nenhuma regra ele desvia." Disponível em: <www.gradesaver.com>. Acesso em: 23 ago. 2011. Tradução nossa.
} 
both matter and words, that the composition be comely; and to do this with diligence and often. ${ }^{9}$

Já no século XVII, podemos destacar o poeta, tradutor, dramaturgo e crítico literário John Dryden, que foi uma figura central tanto na literatura quanto na crítica inglesa, além de ser um dos mais influentes críticos do seu século. Seu trabalho se opôs à crítica incipiente da época, que se pautava na imitação dos clássicos. George de Saintsbury afirma:

He established (...) the English fashion of criticising, as Shakespeare did the English fashion of dramatising, - the fashion of aiming at delight, at truth, as (sic) justice, at nature, at poetry, and letting the rules take care of themselves. ${ }^{10}$

Sua atuação foi reconhecida por outros críticos como Samuel Johnson e, já no século XX, T.S. Eliot. Dryden se diferenciou de seus antecessores por não ser dogmático, não havia, para ele, a necessidade de estabelecer regras, mas procurar encontrá-las, e nem impor julgamentos, e sim mostrar-se cético em sua crítica. Suas leituras não se resumiam apenas à tradição clássica, compreendiam escritores ingleses, como Shakespeare, por exemplo. Dryden foi pioneiro na crítica histórica ao reconhecer a ligação entre a literatura e os diferentes períodos. Além disso, contribuiu com a crítica comparativa ao utilizar-se da análise comparada entre as literaturas greco-romana e francesa e os escritores ingleses. Por fim, contribuiu com a teoria crítica no sentido de

\footnotetext{
9 "De stylo, et optimo scribendi genere - Para um homem escrever bem são necessárias três coisas - ler os melhores autores, observar os melhores oradores, e muito exercício de seu próprio estilo; no estilo considerar o que deve ser escrito, e depois qual o modo. Ele deve antes pensar e planejar seu assunto, então escolher suas palavras, e examinar o peso dele e delas. Então, tomar cuidado em colocar e ordenar tanto o assunto quanto as palavras para que a composição seja bela; e fazer isso com cautela e freqüência." Disponível em: 〈www.everypoet.com>. Acesso em: 23.08.2011. Tradução nossa.

10 "Ele estabeleceu (...) o modo inglês de criticar, como Shakespeare estabeleceu o modo de fazer drama, o modo de ter como alvo o prazer, a verdade, a justiça, a natureza, a poesia, e deixar as regras tomarem conta de si mesmas." SAINTSBURY, George. A history of English criticism. New Delhi: Atlantic, 2004. p.131-132. Tradução nossa.
} 
modificar antigas doutrinas à luz da "modernidade" e renunciar a modelos de outros tempos.

Enfim, Dryden, como pontua Saintsbury, foi:

The first very considerable example in England, if not anywhere, of the critic who (...) attributes no arbitrary or conventional eminence to certain parts of it [of literature] (...) the critic who is never afraid to say "Why". Of the critic who asks whether he does like it [a thing], and whether there is any real reason why he should not like it; of the critic, finally, who tries, without prepossession or convention, to get a general grasp of the book or author, and then to set forth that grasp in luminous language, and with a fair display of supporting analysis and argument. ${ }^{11}$

Samuel Johnson, que viveu no século XVIII, foi outro crítico de destaque e de formação neoclássica. Era preocupado com o bom uso da língua inglesa e sua crítica era baseada em padrões morais, ou seja, para ele, um autor tinha por obrigação retratar personagens moralmente aceitos a fim de influenciar positivamente o leitor. Além disso, Johnson analisou as obras a partir de um contexto histórico e não se importava com os autores que não aceitavam os modelos clássicos. Destacou-se pela sua atuação crítica especialmente na obra Lives of the poets, de 1777, marcada pelas opiniões acerca de autores como Milton, Gray, Dryden e Pope. Nessa obra há um equilíbrio entre biografia e crítica, uma vez que não se interessava somente pelo poeta, mas também pela pessoa. Com relação a essa obra, Saintsbury aponta:

In that combination of biography and criticism, which is so natural that it is wonderful (...). They are full of anecdote, agreeably and crisply told, yet they never descend to mere gossip: their [biographies] criticism of life is almost always just and sound, grave without being

\footnotetext{
11 "O primeiro exemplo muito importante na Inglaterra, se não em qualquer outro lugar, do crítico que (...) não atribui eminência arbitrária ou convencional a certas partes dela [da literatura] (...) o crítico que nunca tem receio de dizer "Por quê"; do crítico que pergunta se ele realmente gosta disso [uma coisa], e se há algum verdadeiro motivo pelo qual ele não devesse gostar disso; do crítico, finalmente, que tenta, sem predisposição ou convenção, obter uma compreensão geral do livro ou autor, e então apresentar aquela compreensão em uma linguagem admirável, com uma demonstração apropriada da análise bem fundamentada e argumentada." Ibid., p. 133. Tradução nossa.
} 
precise (...).Their criticism of literature is all the more valuable for being the criticism of their time. ${ }^{12}$

Ao unir a biografia à crítica, Johnson enfrentou problemas com a sociedade de seu tempo, pois reformulou o tom da escrita biográfica ao revelar os aspectos negativos dos biografados, o que não era usual em sua época. Outro diferencial de sua obra crítica foi não se ater somente a poetas bem conhecidos.

Uma passagem de Lives of the poets, sobre o poeta Abraham Cowley (16181667), exemplifica seu modo de abordagem biográfica:

The life of Cowley (...) has been written by Dr. Sprat, an author whose pregnancy of imagination (...) set him high in the ranks of literature; but his zeal of friendship, or ambition of eloquence, has produced a funeral oration rather than a history: he has given the character, not the life, of Cowley (...). His [Cowley] father was a grocer, whose condition Dr. Sprat conceals under the general appellation of a citizen $(\ldots)^{13}$

A volta aos valores clássicos exercida por esses autores é basicamente uma característica comum à literatura inglesa e aos críticos dos séculos XVI ao XVII. Woolf os abordou em seus ensaios em reconhecimento à importância de suas contribuições à literatura clássica inglesa.

No século $\mathrm{XX}$, um dos críticos de grande importância que precedeu Virginia Woolf, e seu contemporâneo, foi Matthew Arnold, reconhecido como o fundador de um movimento na crítica inglesa cujo objetivo era reajustar a discussão sobre a função

\footnotetext{
12 "Naquela combinação de biografia e crítica, que é tão natural que é maravilhosa (...). Elas são cheias de aspectos curiosos, agradável e vigorosamente contados, mas nunca descendo ao nível da simples fofoca: sua [da biografia] crítica da vida é quase sempre justa e adequada, comedida sem deixar de ser exata (...) sua crítica literária é do maior valor por ser a crítica de seu tempo.” Ibid., p. 226-227. Tradução nossa.

13 "A vida de Cowley (...) foi escrita pelo Dr. Sprat, um autor cuja fecundidade imaginativa (...) o colocou em uma posição elevada da literatura; mas seu entusiasmo pela amizade, ou ambição da eloquência produziu um discurso fúnebre mais que uma história; ele revelou o caráter, não a vida, de Cowley (...). Seu [Cowley] pai era um proprietário de uma mercearia, cuja condição Dr. Sprat oculta sob a denominação de cidadão (...)”. Disponível em:< www.gutenberg.org.>. Acesso em: 25 ago. 2011. Tradução nossa.
} 
social da literatura e da crítica a partir de uma abordagem humanista, isto é, colocar a arte em estreita relação com a sociedade e a cultura. Esta abordagem também aparece em Virginia Woolf, como constatado por Lucia Miguel Pereira, porém, num sentido muito diferente daquele de Arnold. Enquanto este objetivava uma relação da literatura com a sociedade e a cultura tendo como instrumento um texto rigorosamente analítico, Woolf, por seu lado, tinha por preocupação básica o envolvimento do leitor com o texto ensaístico pelo viés artístico, ou seja, o estabelecimento de um conjunto interativo entre autor e leitor por meio de um objeto de arte, o ensaio. $\mathrm{O}$ resultado dessa interação foi chamado de abordagem humanista, isto é, um processo de interatividade no qual o principal componente era o prazer despertado pelo encontro com a arte.

$\mathrm{Na}$ postura de Arnold pode ser observada a influência da crítica do francês Charles-Augustin Saint-Beuve, visto como modelo da crítica moderna. A abordagem do crítico francês é considerada a mais importante do século XIX e se baseava na função social da crítica, no julgamento da obra, assim como do escritor. Com relação à linguagem, deveria ser objetiva e transparente, voltada para os padrões clássicos, em contraponto aos arroubos do Romantismo. Uma passagem do livro de Chris Baldwick se reporta a um texto de Saint-Beuve no qual se refere ao papel do crítico como promotor de uma renovação cultural paralelamente a uma renovação política na época do período revolucionário francês:

Every time political order restores itself and resumes its regular course, literary order tends to fall into line and follow suit as best it can. Under the wing of a guardian power, criticism (when there is criticism) does its work and serves this combined restoration. ${ }^{14}$

\footnotetext{
14 “Toda vez que a ordem política se restaura e retoma seu curso regular, a ordem literária tende a fazer o mesmo e segue o exemplo da melhor maneira possível. Sob a proteção de um poder guardião, a crítica (quando há crítica) faz seu trabalho e serve a essa restauração.” BALDWICK, Chris. The social mission of English criticism 1848-1932. Oxford: Clarendon Press/ OUP, 1987. p.12. Tradução nossa.
} 
Arnold tinha por finalidade elaborar um projeto crítico com o objetivo de reestruturar as atividades intelectuais na Inglaterra. Tentou estabelecer uma relação pacífica entre a cultura e a sociedade a fim de amenizar os conflitos políticos e religiosos de sua época. Dessa forma, sintetizou uma visão humanística da literatura, uma vez que a considerava como algo que dá sentido à vida e à cultura e que torna os seres humanos melhores em uma sociedade impregnada pela industrialização. Para ele, a literatura também funcionava como um complemento das ciências, da religião e da filosofia.

Matthew Arnold buscava uma excelência em relação aos destinos da literatura inglesa e da crítica; os valores culturais e os críticos literários estavam colocados em um mesmo patamar. Essa responsabilidade social da crítica literária é claramente expressa em seu texto "The function of criticism at the present time", de 1864:

It is the business of the critical power, as I said in the words already quoted, "in all branches of knowledge, theology, philosophy, history, art, science, to see the object as in itself it really is."(...). It tends to establish an order of ideas (...) if not absolutely true, yet true by comparison with that which it displaces (...). Presently these new ideas reach society, the touch of truth is the touch of life $(\ldots)^{15}$.

A função da literatura ainda é, mais uma vez, reforçada em outro texto, "The study of poetry", de 1880:

Without poetry, our science will appear incomplete; and most of what now passes with us for religion and philosophy will be replaced by poetry (...). For finely and truly does Wordsworth call poetry 'the impassioned expression which is in the countenance of all science'; and what is a countenance without its expression? Again, Wordsworth

\footnotetext{
15 "É tarefa do poder crítico, como disse nas palavras já citadas, 'em todas as áreas do conhecimento, teologia, filosofia, história da arte, ciência, ver o objeto como ele realmente é em si mesmo. '(...) Ele tende a estabelecer uma ordem de idéias (...) se não totalmente verdadeira, pelo menos verdadeira por comparação com aquilo que substitui (...). Logo essas novas ideias alcançarão a sociedade, o contato com a verdade é o contato com a vida (...)" Disponível em: <www.rlclarke.net>. Acesso em: 28 ago. 2011. Tradução nossa.
} 
finely and truly calls poetry 'the breath and finer spirit of all knowledge' $(\ldots)^{16}$.

Para a consecução do projeto de Arnold, o papel do crítico tinha como objetivo premente a elaboração de um ensaio a partir de um significado exato, ou seja, a compreensão clara e exata da obra, de modo a "to see the object as in itself it really is". Fazia uma análise crítica cujo ponto de partida era o texto em si, sem a interferência de fatores externos, sem que o autor assumisse um partidarismo político. Aparentemente, pode até parecer uma contradição um crítico social que não se valia de conceitos que pudessem remeter a fatores extrínsecos ao texto, no entanto, para Arnold, a função social do crítico era defender uma análise imparcial da obra literária que contribuísse com a melhoria da sociedade.

Por essa razão, não poderia se envolver em querelas partidárias relacionadas ao mundo político, como ocorrera em épocas anteriores. Essa nova forma de conceber o trabalho crítico revela sua imparcialidade:

Everything was long seen, by the young and ardent amongst us, in inseparable connection with politics and practical life. We have pretty well exhausted the benefits of seeing things in this connection, we have got all that can be got by so seeing them. Let us try a more disinterested mode of seeing them; let us betake ourselves to the serener life of the mind and spirit. ${ }^{17}$

Outro ponto de extrema importância no projeto de Arnold diz respeito à questão do julgamento da obra, visto que considerava o crítico como um supervisor dos assuntos

\footnotetext{
16 "Sem poesia, nossa ciência parecerá incompleta; e a maior parte do que consideramos agora como religião ou filosofia será substituída pela poesia. (...). Bela e verdadeiramente Wordsworth denomina poesia "a expressão apaixonada que está na fisionomia de toda ciência"; e o que é a fisionomia sem sua expressão? Mais uma vez, Wordsworth bela e verdadeiramente denomina poesia a essência e o espírito mais refinado de todo conhecimento". BALDWICK, Chris. The social mission of English criticism 18481932. Oxford: Clarence Press/OUP, 1987. p.18-19. Tradução nossa.

17 "Tudo foi considerado por muito tempo pelos jovens e os fervorosos entre nós, em uma conexão inseparável com a política e a vida prática. Praticamente esgotamos os benefícios de ver as coisas nesta conexão, nós conseguimos tudo o que pode ser conseguido em vê-las assim. Vamos tentar um modo mais imparcial de vê-las; vamos nos dirigir para uma vida mais tranqüila de mente e espírito". Ibid., p 22-23. Tradução nossa.
} 
relacionados à literatura. Cabia a ele preparar o caminho para uma época literária mais produtiva no futuro, a reforma da vida intelectual de seu tempo era sentida como algo de suma importância. Insatisfeito com a literatura de sua época, postulava como meta a busca de uma excelência que pudesse resgatar a grandiosidade perdida no período nãoliterário em que vivia e que recuperasse "a golden age of creative literature equivalent to those of Aeschylus or Shakespeare"18. Para isso, muitos obstáculos deviam ser removidos, sendo, pois, necessário estabelecer novos rumos para o futuro da literatura, como comenta Chris Baldwick: "The present time was, for Arnold, an unpoetical age, a depressingly difficult interim period of transition in which obstacles had to be cleared and the ground laid for poetry’s future." ${ }^{, 19}$ Baldwick cita Arnold sobre o assunto:

But if we conceive thus highly of the destinies of poetry, we must also set our standard for poetry high, since poetry, to be capable of fulfilling such high destinies, must be poetry of a high order of excellence. We must accustom ourselves to a high standard and to a strict judgement. ${ }^{20}$

Woolf também se alinha com Arnold quanto à necessidade de mudança da situação da literatura de seu tempo e acredita que a sociedade deva estar pronta para que uma literatura mais crítica e melhor apareça no futuro, como afirma em "How it strikes a contemporary":

(...) it seems that it would be wise for the writers of the present to renounce the hope of creating masterpieces. (...) Time, like a good schoolmaster, will take them [their poems, plays, biographies, novels] in his hands, point to their blots and scrawls and erasions (sic), and

\footnotetext{
18 "Uma idade de ouro da literatura criativa equivalente àquelas de Ésquilo ou Shakespeare." Ibid., p. 20. Tradução nossa.

19 "O tempo atual era, para Arnold, uma era sem poesia, um intervalo de um período de transição difícil e deprimente no qual os obstáculos tinham de ser removidos e a base estabelecida para a poesia do futuro." Ibid., p. 19. Tradução nossa.

20 "Mas se nós concebermos em tão alto grau os destinos da poesia, nós também devemos estabelecer um padrão alto para a poesia, uma vez que a poesia, para ser capaz de satisfazer tais objetivos, deve ser poesia de alta condição de excelência. Nós devemos nos acostumar a um alto padrão e a um julgamento rigoroso.” Ibid., p. 18-19. Tradução nossa.
} 
tear them across; but he will not throw them into the waste-paper basket. $^{21}$

As ideias de Matthew Arnold influenciaram outros críticos, como é o caso de T. S.

Eliot que, inclusive, desejava terminar o projeto literário de Arnold. Primeiramente, como Arnold, ele defendia a teoria de que a criação crítica e a literária são atividades interdependentes. Porém, diferentemente daquele, não acreditava que houvesse períodos alternados entre a produção crítica e a criação, mas que ocorressem ao mesmo tempo. Outro diferencial em relação a Arnold refere-se ao conceito de crítica e criação literária. Segundo Eliot, há uma diferença fundamental de concepção: a criação literária é autotélica, isto é, tem sentido em si própria e não visa a um objetivo, já a crítica versa sobre algo, tendo por finalidade comentar e esclarecer pontos relacionados a obras de arte. Dessa forma, não há a possibilidade de união entre criação e crítica, mas sim da crítica com a criação, originando, desse modo, uma crítica bem elaborada, como afirma no ensaio "The function of criticism", de 1923, citado por Baldwick:

Matthew Arnold distinguishes far too bluntly, it seems to me, between two activities: he overlooks the capital importance of criticism in the work of creation itself. (...) I maintain even that the criticism employed by a trained and skilled writer on his work is the most vital, the highest kind of criticism (...) I have assumed as axiomatic that a creation, a work of art, is autotelic, and that criticism, by definition, is about something other than itself. Hence you cannot fuse creation with criticism as you can fuse criticism with creation. The critical activity finds its highest, its true fulfillment in a kind of union with creation in the labour of the artist. ${ }^{22}$

\footnotetext{
21 “(...) parece que seria sábio para os escritores da atualidade renunciar à esperança de criar obras-primas. (...) o Tempo, como um bom mestre, vai levá-los [seus poemas, peças, biografias, romances] pela mão , apontar seus borrões e rasuras e os rasgará. Mas ele não os jogará na lixeira de papel." WOOLF, Virginia. The common reader. New York: Harvest/Harcourt, 1984. p. 240. Tradução nossa.

22 "Matthew Arnold distingue abruptamente, me parece, entre duas atividades: ele negligencia a importância fundamental da crítica no trabalho da criação em si. (...) Eu afirmo até que a crítica utilizada por um escritor experiente e habilidoso sobre seu trabalho é o mais importante, o mais elevado tipo de crítica (...). Eu tenho como princípio que a criação, um trabalho artístico, é autotélico; e que a crítica, por definição, é sobre algo diferente de si mesmo. Portanto, não se pode unir a criação com a crítica como se pode unir a crítica com a criação. A atividade crítica encontra seu ponto máximo, sua completa realização em um tipo de associação com a criação no trabalho do artista." BALDWICK. Chris. The social mission of the English criticism 1848-1932. Oxford: Clarendon/OUP, 187. p.116-117. Tradução nossa.
} 
Eliot também enfatiza neste texto a importância da tradição dos escritores ingleses do século XVII, aliás, ele próprio se denominava "a classicist in literature, royalist in politics and anglo-catholic in religion" 23 e argumentava que a crítica deveria contemplar não só os contemporâneos, mas também reconhecer a contribuição do passado. Isso seria no sentido de proporcionar uma adequação presente-passado e reforçar a união entre a criação literária e a crítica, ao considerar suas existências simultâneas ("simultaneous order"). Para ele, a literatura europeia, desde Homero, havia formado uma única tradição literária capaz de atribuir relevante importância tanto às obras de arte quanto aos escritores:

(...) the historical sense involves a perception not only of the pastness of the past, but of its presence; the historical sense compels a man to write not merely with his own generation in his bones, but with a feeling that the whole of the literature of Europe from Homer and within it the whole of the literature of his own country has a simultaneous existence and composes a simultaneous order. ${ }^{24}$

Tanto Eliot quanto Matthew Arnold e Woolf acreditam que a tradição literária seja um fator importante para a compreensão das obras contemporâneas. Assim, ela escreve no ensaio "Hours in a library", de 1916:

Take Shakespeare, or Milton, or Sir Thomas Browne. (...) Did we ever in our youngest days feel such amazement at their achievement (...)? New books may be more stimulating and in some ways more suggestive than the old, but they do not give us that absolute certainty of delight which breathes through when we come back again to Comus, or 'Lycidas' $(\ldots)^{25}$.

\footnotetext{
23 "Um classicista na literatura, um monarquista na política e um anglo-católico na religião.” Ibid., p. 109.

24 “(...) o senso histórico envolve uma percepção não só do caráter passado do passado, mas de sua presença; o senso histórico impele um homem a escrever não somente com sua própria geração em seus ossos, mas com um sentimento de que a totalidade da literatura da Europa desde Homero e dentro dela a totalidade da literatura de seu próprio país tem uma existência simultânea e constitui uma ordem simultânea.” Ibid., p. 120. Tradução nossa.

25 "Veja Shakespeare, Milton, ou Sir Thomas Browne. (...) Alguma vez sentimos em nossa juventude tal admiração pelos seus êxitos (...)? Os livros novos podem ser mais estimulantes e de alguma forma mais sugestivos que os antigos, mas eles não nos dão aquela certeza absoluta de deleite que se manifesta quando voltamos outra vez a Comus, ou "Lycidas", (“...)." MCNEILLE, Andrew. The essays of Virginia Woolf. Vol. 2 1920-1924. New York: Harcourt Brace Jovanovich, 1987. p. 60. Tradução nossa.
} 
A visão crítica de Eliot também privilegia o aspecto social ao reconhecer as especificidades culturais, como ressalta no ensaio "Tradition and the individual talent", de 1920: "Every nation, every race, has not only its own creative, but its own critical turn of mind; and is even more oblivious of the shortcomings and limitations of its critical habits than those of its creative genius." ${ }^{26}$ Cabe ao crítico adaptar seus valores sociais a fim de dar continuidade à tradição literária europeia. A atitude baseada em uma perspectiva histórica permite ao artista ficar atento ao seu tempo e refletir sobre a sociedade em que vive.

Eliot e Arnold valorizam a objetividade e a importância delegadas ao poder de julgamento e à função social da crítica. Com relação à objetividade, nesse mesmo texto, Eliot afirma que “(...) the most important qualification which I have been able to find, which accounts for the peculiar importance of the criticism practitioners, is that a critic must have a very highly developed sense of fact." ${ }^{27}$ Eliot reforça a imparcialidade da análise ao questionar a crítica baseada em uma opinião bem fundamentada, em detrimento de um julgamento literário que considere somente a obra de maneira vaga e superficial. Defende que o verdadeiro crítico deve deter um sólido conhecimento dos fatos sobre o trabalho artístico no tocante às suas condições, adequações e origens. Em outras palavras, é necessário que apresente ao leitor os aspectos técnicos da obra de arte de modo a proporcionar seu amplo entendimento. É imprescindível que o crítico se atenha ao texto guiado pelo conhecimento advindo da tradição literária, aproximando,

\footnotetext{
26 "Cada nação, cada raça, não tem somente sua própria atitude criativa perante a vida, mas crítica também; e ainda está mais esquecida das imperfeições e limitações de seus hábitos críticos do que daqueles de seu gênio criativo.” Disponível em: <www.bartleby.com>. Acesso em: 01 set. 2011. Tradução nossa.

27 “(...) a mais importante qualificação que consegui achar, que explica a importância característica dos críticos profissionais, é que um crítico deve ter um entendimento da realidade muitíssimo desenvolvido." BALDWICK, Chris. The social mission of English criticism 1848-1932.Oxford: Clarendon Press/OUP, 1987. p. 117. Tradução nossa.
} 
dessa maneira, a elaboração da crítica a um enfoque científico, como afirma na obra

Sacred wood, de 1920:

English criticism is inclined to argue or persuade rather than to state; and, instead of forcing the subject to expose himself, these critics have left in their work an undissolved residuum of their own good taste, which, however impeccable, is something that requires our faith. ${ }^{28}$

Em The use of poetry and the use of criticism, Eliot, ao afirmar que "every hundred years or so, it is desirable that some critic shall appear to review the past of our literature, and set the poets and the poems in a new order" ${ }^{29}$ não podia prever que dois críticos ingleses em Cambridge articulavam um projeto de reavaliação da poética inglesa e que seriam os pioneiros de uma análise crítica dos romancistas ingleses: F. R. e sua esposa, Q. D. Leavis.

Suas obras críticas foram publicadas em veículos distintos como, por exemplo, no livro The great tradition (1948), de F. R. Leavis, que versa sobre os aspectos sociais, históricos e éticos da literatura e na revista de crítica Scrutiny, lançada por ele e sua esposa Q. D. Leavis em 1932, cujo foco era a avaliação das obras literárias com ênfase na descrição e na análise de pormenores textuais e linguísticos. Na realidade, a análise literária encontrada na Scrutiny estava ligada à crítica prática, uma detalhada interpretação analítica conduzida por um "close reading" e isolada do contexto histórico-social. Tal tipo de análise serviu de base para a teoria da Nova Crítica que surgiu nos Estados Unidos nas décadas de 20 e 30 e alcançou sua maior repercussão em 1950.

\footnotetext{
28 "A crítica inglesa tende a argumentar ou persuadir mais que afirmar; e, ao invés de obrigar o sujeito a se expor, estes críticos deixaram em seu trabalho um resíduo indissolúvel de seu bom gosto, que, embora irrepreensível, é algo que exige nossa fé." Ibid., p. 118. Tradução nossa.

29 “A cada cem anos mais ou menos, é desejável que algum crítico apareça para rever o passado de nossa literatura, e colocar os poetas e os poemas em uma nova ordem.” Ibid., p. 162. Tradução nossa.
} 
Os Leavises defendiam que a linguagem utilizada na literatura deveria ser preservada por uma minoria a fim de evitar sua deterioração pelo uso cotidiano da sociedade de massa. Para eles, a banalização do idioma poderia ser evitada por meio de um processo educacional de valorização da língua denominado "Englishness" propunha-se que algumas formas de expressão eram superiores a outras e uma parte da população deveria atuar como guardiã da língua e reforçar sua defesa como uma instituição. Percebe-se nessa crítica uma rígida preocupação no sentido de estabelecer parâmetros literários contra a invasão e o domínio da linguagem coloquial, o que a torna uma crítica de perfil impositivo. Uma passagem do livro de F. R. Leavis, For continuity, citada por Baldwick, ilustra nossa afirmação:

The minority capable not only of appreciating Dante, Shakespeare, Donne, Baudelaire, Hardy (...) constitute the consciousness of the race (...).Upon this minority depends our power of profiting by the finest human experience of the past (...). Upon them depend the implicit standards that order the finer living of one age, the sense that this is worth more than that, this rather than that is the direction in which to go, that the centre is here rather than there. ${ }^{30}$

A missão da revista Scrutiny, portanto, foi divulgar, reorganizar e preservar esses novos parâmetros literários, até então, conhecidos apenas entre poucos e principalmente pelos intelectuais da esfera acadêmica.

Podemos perceber quatro momentos pelos quais passou a produção literária de F. R. Leavis. Nas primeiras obras e ensaios, sua preocupação voltava-se para o reexame da poesia do século XVII ao XX. Num momento posterior, ocupou-se com a ficção e o romance. Durante esse período a obra The Great tradition foi escrita com o objetivo de

\footnotetext{
${ }^{30}$ A minoria capaz não só de apreciar Dante, Shakespeare, Donne, Baudelaire, Hardy (...) constitui a consciência da raça (...). Dessa minoria depende nosso poder de tirar proveito da mais refinada experiência humana do passado (...). Deles dependem os padrões implícitos que determinam a mais requintada existência de uma época, a ideia de que isso vale mais que aquilo, de que esse é o caminho a seguir, de que o centro está aqui e não lá.” Ibid., p. 164-165.Tradução nossa.
} 
determinar a importância do romance após a experiência da guerra, e, embora o escritor tenha vivido em um período marcado pelas ideologias fascista e comunista, seu foco de atenção dirigiu-se para um romance voltado à experiência da vida. Jane Austen, George Eliot, Henry James e Joseph Conrad são alguns dos autores contemplados em sua obra, porque, segundo Leavis, incitam à consciência da importância da vida.

A obra de Q. D. Leavis, Fiction and the reading public, de 1932, procura explicar o contexto no qual a cultura literária se encontrava, o que possibilita entender a fundamentação dos parâmetros literários instituídos. Baldwick cita uma passagem em que contrapõe o século XX à era elisabetana, durante a qual, apesar de não haver o cinema para a distração das massas, "they possessed an enormously rich heritage of proverbial wisdom, music, ballads, and folk -history. They had a lore, while today's literate masses have only information, 'a kind of knowledge not rooted in the soil...",31.

A obra de Q. D. Leavis expõe sua preocupação com o público leitor, mas, diferentemente de Woolf, ressalta uma distinção do público de acordo com seu grau de instrução, pensando, dessa maneira, na formação de uma elite interessada na leitura. Tal concepção vai de encontro ao do "leitor comum" defendido por Woolf, pois sua preocupação substancial é com a efetiva participação de um leitor destituído completamente de traços acadêmicos, cujo propósito essencial é o prazer literário a partir do envolvimento estético com o texto e pela reflexão crítica motivada pelos jogos cognitivos engatilhados pelo autor.

Transcrevemos uma passagem do ensaio "The contemporary situation" da obra supra-citada de Q. D. Leavis, com seu posicionamento ao confrontar com o "leitor

\footnotetext{
31 "Eles tinham uma herança muitíssimo rica de sabedoria proverbial, música, baladas, e história popular. Eles tinham um saber, ao passo que hoje as massas letradas só têm informação, 'um tipo de conhecimento não enraizado no solo..." BALDWICK, Chris. The social mission of English criticism 1848-1932. Oxford: Clarendon Press/OUP, 1987. p. 177. Tradução nossa.
} 
comum” de Samuel Johnson e Woolf: “(...) the general public- Dr Johnson's common reader- has now not even a glimpse of the interests of modern literature, is ignorant of its growth and so prevented from developing with it (...) ${ }^{\text {,32 }}$.

Sua crítica centrou-se nos romances do século XIX e XX, principalmente os de literatura feminina. Uma de suas análises é o ensaio "Caterpillars of the commonwealth unite!”, de 1938, em que analisa a obra Three guineas, de Virginia Woolf:

(...) the release of sex hostility this kind of writing represents is selfindulgent because it provides Mrs. Woolf with a self-righteous glow at the cost of furnishing an easy target for unsympathetic males, and at the still greater cost of embarrassing those women who are aware that the only chance of their getting accepted as intellectual equals by intelligent men (...) is by living down their sex's reputation for having in general minds as ill-regulated as Mrs. Woolf is here seen to be. ${ }^{33}$

Em resposta a esse posicionamento, Woolf afirma:

A violent attack on Three Guineas in Scrutiny by Q.D. Leavis. I don't think it gave me an entire single thrill of horror. And I didn't read it through. A symbol though of what wiggings are to come. But I read enough to see that it was all personal-about Queenie's own grievances and retorts to my snubs. ${ }^{34}$

A passagem escrita por Q. D. Leavis é um tipo de julgamento crítico

frequentemente exercido pela ensaística inglesa vigente naquela época da qual Woolf

muito se distinguiu, não apenas quanto aos Leavises, mas também em relação aos

\footnotetext{
32 “(...) o público em geral - o leitor comum do Dr. Johnson - agora não tem o mínimo interesse na literatura moderna, é ignorante do seu crescimento e, assim, está impedido de se desenvolver com ela." LEAVIS, Q. D. Fiction and the reading public. London: Penguin, 1979. p. 42. Tradução nossa.

33 “(...) a liberação de hostilidade sexual que este tipo de escrita representa é auto-indulgente porque ele confere a Sra. Woolf um brilho farisaico à custa de fornecer um alvo fácil para os homens não compreensivos e ainda ao maior custo de embaraçar aquelas mulheres que têm consciência de que a única possibilidade de serem aceitas intelectualmente da mesma forma pelos homens inteligentes (...) é fazer esquecer a reputação de seu sexo por terem mentes tão mal reguladas quanto a Sra. Woolf aqui parece ter." Disponível em: <mypages.surrey.ac.uk>. Acesso em: 03/09/2011. Tradução nossa.

34 “Um ataque violento em relação a Three Guineas na Scrutiny por Q. D. Leavis. Eu não acho que me fez sentir horrorizada. E eu não o li por inteiro. Um sinal, entretanto, de que repreensões estão por vir. Mas eu li o suficiente para entender que ele foi totalmente pessoal sobre as próprias queixas e réplicas de Queenie à minha indiferença..” Revista Alicantina de estúdios ingleses. p. 214. Disponível em: <http://rua.ua.es>. Acesso em: 03 set. 2011. Tradução nossa.
} 
demais críticos ingleses. O não-julgamento é uma das potenciais características do ensaio virginiano e sobre isso Lucia Miguel Pereira comenta em "Crítica e feminismo":

De fato, o que faz é dar vida ao autor que estuda, para poder tratá-lo familiarmente, como a um velho amigo, com quem se discute, de quem às vezes se zomba, mas a quem se quer bem. Evocados por ela (...) Chaucer e Shakespeare, Defoe e Jane Austen se fazem espantosamente próximos e fáceis de abordar. Não que os simplifique (...) mas porque sabe como penetrar até eles, até as pessoas que foram. Tudo lhe parece claro, e quente, e vivo, como se acabasse de acontecer. $^{35}$

E ainda, como avalia em "O ofício de compreender":

À vaidade do julgamento, é sempre preferível a sinceridade da simples explicação. Só esta pertence à alçada do crítico. O que não exclui, de maneira alguma, a liberdade de exame, de discussão. Só se discute, honestamente, aquilo que se acata; como só se pode acatar o que se entendeu, embora sem aceitar. ${ }^{36}$

No ensaio "How should one read a book?", do livro The second common reader,

de 1935, Woolf trata da questão do julgamento literário. Ressaltamos que ela se utiliza do verbo “judge” (julgar) em seu texto, porém, a acepção ali não se refere a uma prática impositiva que escolha entre o certo e o errado mediante técnicas padronizadas de leitura, mas, sim, a uma análise sobre a qual possa fundamentar seu ponto de vista baseado em uma reflexão consistente sobre o assunto tratado e com a devida sensibilidade e prazer que são tipicamente dedicados a uma obra de arte. Dessa forma, volta-se, mais uma vez, ao conceito do crítico como um "leitor comum":

We must remain readers; we shall not put on the further glory that belongs to those rare beings who are also critics. But still we have our responsibilities as readers and even our importance. (...) If (...) the author felt that there was another kind of criticism, the opinion of people reading for the love of reading, slowly and unprofessionally, and judging with great sympathy and yet with great severity, might this not improve the quality of his work? ${ }^{37}$

\footnotetext{
${ }^{35}$ PEREIRA, Lúcia Miguel. Escritos da maturidade. Rio de Janeiro: Grafia, 2005. p. 112.

${ }^{36}$ PEREIRA, Lucia Miguel. O leitor e seus personagens. Rio de Janeiro: Grafia, 2005. p. 92.

37 "Nós devemos continuar a ser leitores; nós não aumentaremos a glória posterior que pertence àqueles seres raros que também são críticos. Mas contudo nós temos nossas responsabilidades como leitores e ainda nossa importância. (...)Se (...) o autor sentisse que houve um outro tipo de crítica, a opinião das pessoas que lêem pelo amor à leitura, vagarosa e amadoristicamente, e julgando com grande simpatia,
} 
Com relação à união da crítica com a criação literária, Lucia Miguel Pereira afirma que o resultado dessa interação é a coexistência das linguagens narrativa e crítica no ensaio virginiano, quando menciona em "Crítica e feminismo" que "graças ao primeiro [senso lírico] pode recriar" ${ }^{38}$ uma nova forma para o ensaio utilizando-se de seus atributos e de suas habilidades como ficcionista e crítica literária. Esse assunto, como assinalado, foi objeto de discussão para Eliot em "The function of criticism", que acreditava que a crítica bem elaborada deveria originar-se da união com a criação artística, pressupondo, assim, um artista-crítico. Woolf compartilha dessa visão de Eliot, como afirma Mark Goldman, em The reader's art: Virginia Woolf as literary critic, ao referir-se ao ensaio de Woolf sobre o pintor "Roger Fry”: “(...) Mrs. Woolf endorses the value of the artist-critic (...) on the creative work of Roger Fry." ${ }^{, 39}$

$\mathrm{Na}$ verdade, além de todo o diálogo entre Woolf e seus compatriotas predecessores e contemporâneos, a forma do ensaio virginiano também se aproxima muito das concepções do filósofo alemão Theodor Adorno (1903-1969), cujo texto "O ensaio como forma", em Notas de literatura I, apresenta uma série de reflexões acerca desse gênero literário. Como está claro no título do texto de Adorno, a forma é o próprio ensaio em cada momento de sua fatura, sem obedecer a regras pré-estabelecidas e como produto resultante de um acaso que se assemelha à "felicidade e [ao] jogo" ${ }^{40}$. A partir desse processo, cada ensaio torna-se diferente do outro e sua identidade está justamente nessa falta de uma estrutura previamente estipulada. A unidade que caracteriza o ensaio

mas com muito rigor, isso não poderia melhorar a qualidade de seu trabalho?" WOOLF, Virginia. The second common reader. New York: Harcourt, 1986. P. 269-270. Tradução nossa.

${ }^{38}$ PEREIRA, Lucia Miguel. Escritos da maturidade. Rio de Janeiro: Grafia, 2005. p.113.

39 “A Sra. Woolf endossa o valor do artista-crítico (...) no trabalho criativo de Roger Fry.” GOLDMAN, Mark. The reader's art: Virginia Woolf as literary critic. Paris: Mouton, 1976. p. 93. Tradução nossa.

40 ADORNO, Theodor. Notas de literatura I. Trad. de Jorge de Almeida. São Paulo: Duas Cidades/Editora 34 .p. 17 
deve ser aquela mais apropriada ao conteúdo a ser tematizado, levando-se em consideração a liberdade de uso da expressão pessoal sem qualquer tipo de dogmatismo:

O ensaio (...) não admite que seu âmbito de competência lhe seja prescrito. Em vez de alcançar algo cientificamente ou criar artisticamente alguma coisa, seus esforços ainda espelham a disponibilidade de quem, como uma criança, não tem vergonha de se entusiasmar com o que os outros fizeram. O ensaio reflete o que é amado e odiado, em vez de conceber o espírito como uma criação a partir do nada (...). O ensaio recua, assustado, diante da violência do dogma, que atribui dignidade ontológica ao resultado da abstração, ao conceito invariável no tempo, por oposição ao individual nele subsumido. ${ }^{41}$

As concepções estéticas de Woolf a respeito do ensaio também se aproximam de György Lukács (1885-1971), outro filósofo cujas reflexões sobre o tema levam a um redimensionamento da definição e da finalidade do ensaio. No texto "On the nature and form of the essay", da obra Soul and form, Lukács se opõe a uma visão cientificista da ensaística e afirma que "science affects us by its contents, art by its forms; science offers us facts and the relationships between facts, but art offers us souls and destinies." $" 42$

Se de acordo com as afirmações de Lukács, o ensaio não possui uma natureza científica, mas artística, sua maior finalidade, então, seria a de causar prazer por meio da beleza ou do estranhamento e, o mais importante, integrar o autor e o receptor da obra numa relação humana para que juntos deem sentido à existência do objeto artístico. Tal assunto suscitou muito debate, e a esse respeito, Woolf escreveu em "The modern essay": "Vague as all definitions are (...) it [the essay] must draw its curtains round us,

\footnotetext{
${ }^{41}$ Ibid., p.16-17/25.

42 "A ciência nos afeta pelo seu assunto, a arte pela suas formas; a ciência nos oferece fatos e relações entre fatos, mas a arte nos oferece almas e destinos." LUCKÁCS, Gyöfgy apud ROSENBERG, Beth Carole/ DUBINO, Jeanne. Virginia Woolf and the essay. New York: St. Martin's Press, 98. p. 11.Tradução nossa
} 
but it must be a curtain that shuts us in, not out." ${ }^{, 43}$. Desse modo, Woolf sinaliza à existência do ensaio o objetivo de aproximar autor e receptor por meio de uma elaboração contrária àquela de natureza científica que, pelo rigor de sua forma, só poderia ser recebida por um leitor altamente especializado no assunto, como vimos na estrutura ensaística dos Leavises, por exemplo. Apenas uma obra de arte consegue um grau de interação tão profundo capaz de envolver o leitor e trazê-lo para seus domínios. Isso concretiza a impossibilidade de definir o ensaio como um instrumento essencialmente científico.

Em Woolf, a identidade do ensaio é caracterizada pela união da linguagem narrativa e da crítica, o que acaba por proporcionar uma nova arquitetura da forma definida a partir de sua escritura e cujo "principle which controls it is simply that it should give pleasure". ${ }^{44}$ É por essa razão que a escritora inglesa afirma que "the art of writing has for backbone some fierce attachment to an idea, something believed in with conviction or seen as with precision and thus compelling words to its shape." $"$ Ao escolher como princípio fundamental a articulação de dois tipos de linguagem, Woolf tem como objetivo não apenas reestruturar o conceito e o objetivo do ensaio, mas também utilizá-lo como uma fonte geradora de prazeres estéticos.

De acordo com Lucia Miguel Pereira, a natureza do ensaio de Woolf é de caráter plural e não-científico, "não obedece a sistemas, não é científica, nem impressionista, nem moralista, nem esteta: não classifica, não rotula, não distribui bons e maus

\footnotetext{
43 "Vagas como são todas as definições (...) ele [o ensaio] deve descerrar suas cortinas ao nosso redor, mas deve ser uma cortina que nos atraia para dentro, não que nos impeça de entrar." WOOLF, Virginia. The common reader. New York: Harvest/Harcourt, 1984. p. 222.

44 "princípio que o controla é simplesmente aquele que deve nos causar prazer." Ibid., p. 211. Tradução nossa.

45 “a arte de escrever tem por sustentáculo algum vínculo muito forte a uma ideia, algo em que se acredita com convicção ou que se vê com precisão e assim que impele as palavras à sua forma.” Ibid., p. 221. Tradução nossa.
} 
pontos" ${ }^{\text {;6; }}$ seu texto é construído a partir de uma linguagem mista e de uma maneira muito peculiar no tratamento dos temas que surge sob uma forma aparentemente fragmentária ao "perambular" por diferentes possibilidades analíticas, demonstrando, assim, um "ar de excursionista" 47 . Há, como resultados, um pretenso abandono da forma e o aparecimento de um jogo de ideias espalhado pela superfície do texto, o que acarreta ao ensaio uma espécie de informalidade, um tom casual que foge à estrutura acadêmica e atrai a atenção do leitor pelo estranhamento que provoca.

Vem daí o atributo humanista que impele o leitor à leitura prazerosa e que o instiga a participar do jogo pela reflexão sobre o texto analisado. $\mathrm{O}$ movimento proposto pela escrita de Woolf é identificado por Pereira quando a analisa como leitora. Para a crítica brasileira, Woolf escreve seus ensaios da mesma maneira como lê os livros pelos quais se interessa, agindo como um "leitor comum", termo utilizado pelo intelectual inglês do século XVII, Samuel Johnson (1709-1784), que revela um leitor que lê tão somente pelo prazer da leitura, sem interesses acadêmicos. Woolf, ao buscar proporcionar prazer ao seu leitor, rearticula a estrutura ensaística a fim de deixar transparecer o mesmo prazer que sentira ao ler a obra que analisa. Não por acaso, na introdução de The common reader, ela cita a definição do leitor comum de acordo com Johnson: “(...) [ he/she] differs from the critic and the scholar. He is worse educated, and nature has not gifted him so generously. He reads for his own pleasure rather than to impart knowledge or correct the opinions of others."48

Virginia Woolf leva a experiência ao extremo ao unir crítica e criação pela adequação de ambas as linguagens. Enquanto seus predecessores transitaram pelo

\footnotetext{
${ }^{46}$ PEREIRA, Lucia Miguel. Escritos da maturidade. Rio de Janeiro: Grafia, 2005. p. 112.

${ }^{47}$ Ibid., p. 111.

48 “(....) [ele/ela] se diferencia do crítico e do erudito. Ele não é tão instruído e a natureza não o capacitou muito generosamente. Ele lê para seu próprio prazer mais do que para transmitir conhecimento ou corrigir as opiniões dos outros." WOOLF. Virginia. The common reader. Harvest/Harcourt, 1984. p. 1. Tradução nossa.
} 
ensaio acadêmico de linguagem retórica e forma padronizada, ela libertou-se dos dogmas e das regras sem causar fraturas letais com a tradição pré-existente e livrou o ensaio das garras do cientificismo, elevando-o à categoria de arte sem, no entanto, comprometer o seu rigor analítico.

Se, de Ben Jonson a Arnold, Eliot e os Leavises, o ensaio passou por diferentes concepções, estruturações e finalidades, em Virginia Woolf ele reuniu todos os conceitos anteriores aliados, ainda, à forma concebida por Montaigne, a qual é um instrumento de opiniões pessoais, um espaço para as ilações e propostas reflexivas de seu autor, isento das comprovações científicas, das dissecações expositivas e das precisões cirúrgicas; ainda mais, definiu-se como o local das interações humanas, das preocupações com o outro, das propostas desafiadoras da inteligência do leitor e, acima de tudo, como um nicho de prazer resultante da fruição estética que só se obtém por meio da arte. Virginia Woolf passou a sintetizar as características anteriores do ensaio como uma forma criadora de um espaço onde todos os conceitos sobre a ensaística se irradiam e no qual os contrários e os afins se encontram em harmonia, formando, desse modo, uma unidade articulada pelas diferenças e complementaridades: linguagem crítica e narrativa, emoção e consciência político-social, integração entre a mente criadora masculina que encerra a razão e a feminina que comporta a sensibilidade e opiniões pessoais particulares bem embasadas, sem a necessidade de comprovações científicas. A forma do ensaio virginiano é congregadora e conciliadora; funda uma dimensão que recria a tradição ensaística inglesa em diálogo e completude com as inovações da modernidade. A nova forma, em suma, posiciona o ensaio como um objeto que promove reflexões cognitivas e ao mesmo tempo como um espaço de prazeres estéticos, um objeto de arte. 
Em $A$ room of one's own, analisado por Lucia Miguel Pereira em Crítica $e$ feminismo, Virginia Woolf dá contornos nítidos ao seu conceito estético para a criação literária (que já havia iniciado anteriormente e aprofundado em The common reader), e arquiteta o princípio teórico que sustentará uma nova forma não só para o ensaio como também para todas as criações literárias: o conceito de androginia.

A obra foi originalmente apresentada, de maneira condensada, em forma de artigos lidos nas faculdades de Newnham e Girton na cidade de Cambridge, em 1928, e pode ser denominada de ensaio-ficção, pois foi construída a partir de uma narrativa parcialmente ficcionalizada na qual uma narradora imaginária reflete sobre a criação literária. Sua reflexão leva em consideração, além do conceito de androginia como base para uma construção perfeita do texto ficcional, aspectos que se relacionam às condições de produção literária por homens e mulheres no tocante a várias questões, inclusive a financeira. No entanto, nosso enfoque será apenas o estético, sobre o conceito de androginia como forma, de acordo com a concepção de Woolf e o ponto de vista de Lucia Miguel Pereira sobre essa teoria.

Com relação à origem do conceito, pode-se voltar a Platão (428/427 a.C - 347 a. C), em $O$ banquete, para quem na origem da humanidade havia três espécies de pessoas: o macho, a fêmea e um terceiro gênero formado pelos dois primeiros, chamado de Andrógino. Esses seres não eram nem filhos do Sol, como os homens, nem da Terra, como as mulheres, mas filhos da Lua. Como eram completos e possuíam muito poder, tornaram-se ambiciosos e escalaram o Olimpo, declarando guerra aos deuses, e, por isso, foram castigados por Zeus que, através de um raio, separou seus corpos irreversivelmente. 
A defesa da fusão do masculino com o feminino por Woolf é, simultaneamente, a síntese e o ponto de partida inicial de sua concepção dos dualismos da realidade que formam uma unidade harmônica. Convivem o material e o espiritual, a ficção e o histórico, o comum e o fantástico, a luz e a sombra e a linguagem crítica e a narrativa. Virginia Woolf acredita que cabe ao escritor absorver todas essas diferentes impressões e sintetizar tal complexidade a fim de construir uma nova forma literária através de sua mente criadora.

É, na realidade, uma busca da totalidade por meio da união dos opostos como forma estética para qualquer gênero literário e, mais especificamente, no caso desse nosso capítulo, o ensaio.

O conceito de androginia como teoria básica para a criação literária também pode ser encontrado no conto "The mark on the wall", da coletânea A haunted house, um texto que mostra "o próprio processo de composição de Virginia Woolf" ${ }^{49}$. Nesse conto, a narradora tenta descobrir o que é uma marca deixada na parede de um determinado cômodo. A partir daí, seu pensamento percorre dois caminhos distintos: o primeiro é o das divagações, quando liga a marca aos mais diversos significados numa espécie de errância pelas variadas possibilidades de sentido daquele fato; já o segundo dá-se pelo viés das reflexões críticas, no momento em que aquelas divagações passam a suscitar discussões acerca dos fatos da realidade. Um bom exemplo disso é aquele em que, num dado momento do enredo, a narradora inicia uma reflexão sobre a sociedade patriarcal a partir das mais diferentes interpretações sobre a natureza daquela marca na parede. No final, ela descobre que a marca era nada mais do que um caramujo, ou seja, não se tratava de um desenho, mas de uma realidade material. Entendemos, então, que a impressão (marca na parede), fonte das possibilidades abstratas, está intrinsecamente

\footnotetext{
${ }^{49}$ PEREIRA, Lucia Miguel. Escritos da maturidade. Rio de Janeiro: Grafia, 2005. p. 127.
} 
ligada à realidade material (o caramujo), coexistindo e interagindo na criação dos sentidos das formas, assim como na estrutura da forma propriamente dita.

Além do mais, de acordo com Herbert Marder, em Feminismo e arte, o caramujo pode ser interpretado como um símbolo da união entre o masculino e o feminino, ou seja, a mente andrógina, uma vez que traduz uma interação harmônica entre dois conceitos opostos, formando, assim, uma unidade, a qual nada mais é do que a nova forma de criação literária concebida por Woolf. A crítica inglesa defende a fusão de elementos masculinos e femininos como uma forma de completude que leva a uma unidade interativa perfeita, capaz de estabelecer um equilíbrio dinâmico entre o polo masculino e o feminino:

(...) in each of us two powers preside, one male, one female; and in the man's brain the man predominates over the woman, and in the woman's brain, the woman predominates over the man. The normal and comfortable state of being is that when the two live in harmony together, spiritually co-operating. If one is a man, still the woman part of his brain must have effect; and a woman also must have intercourse with the man in her. ${ }^{50}$

Lucia Miguel Pereira afirma em Crítica e feminismo que, para Virginia Woolf, a ficção produzida pela maioria das mulheres de seu tempo era insatisfatória, uma vez que as escritoras compunham suas obras utilizando-se apenas da visão feminina. Da mesma forma, escritores como Rudyard Kipling (1865-1936) e John Galsworthy (1865-1936) enalteciam exageradamente as "male virtues", 51 estabeleciam "male values" e

\footnotetext{
50، (...) em cada um de nós, presidiriam dois sexos, um masculino e um feminino; e, no cérebro do homem, o homem predomina sobre a mulher, e, no cérebro da mulher, a mulher predomina sobre o homem. O estado normal e confortável é aquele em que os dois convivem junto em harmonia, cooperando espiritualmente. Quando se é homem, ainda assim a parte feminina do cérebro deve ter influência; e a mulher deve também manter relações com o homem em seu interior." WOOLF, Virginia. Um teto todo seu. Tradução Vera Ribeiro. Rio de Janeiro: Nova Fronteira, 1985. p. 128-129.

51“virtudes masculinas". Ibid., p. 133.
} 
evidenciavam exclusivamente "the world of men", não possuindo "a spark of the woman in him" ${ }^{, 53}$. Isso significa que estas produções literárias estavam à margem das concepções da unidade de criação sustentada pela androginia como forma, e, se no caso das mulheres a ausência da forma andrógina legava sua produção à inferioridade, no universo dos escritores as obras nasciam secas, duras, isto é, "they lack[ed] suggestive power" ${ }^{, 54}$. Com isso, Woolf critica a falta de uma linguagem mais intimista e imaginativa devido à preponderância do lado masculino do cérebro. No entanto, o mesmo não acontecia com autores como Shakespeare, Keats, Sterne, entre outros, que, pelo fato de escreverem sob a unidade da androginia, produziram grandes obras.

De acordo com a crítica brasileira, em A room of one's own Woolf aflora muito mais como pessoa do que como crítica literária. É nesse espaço que emergem seus conflitos existenciais, paradoxos ideológicos, recalques psicológicos, constrangimento do sexo, amargor e ressentimento contra o masculino e, além de tudo, Virginia Woolf entrega-se a uma tentativa frustrada e confusa ao apresentar sua abordagem de criação literária pelo viés do mito do andrógino. Sobre essa abordagem, Pereira ainda afirma que o princípio da androginia como uma nova forma para o ensaio e para a criação literária em geral não sustenta a composição estética do texto, mas surge apenas como uma confusão, uma espécie de confissão intelectual caótica da autora acerca de suas relações de inferioridade com relação ao próprio sexo e com o mundo masculino. $\mathrm{O}$ rancor e o ressentimento contra os homens, que havia identificado nas escritoras de sua geração, e que explicariam a ausência da união entre o masculino e o feminino como estética criadora na literatura feminina, seriam sentimentos da própria Woolf, manifestados sob a roupagem de crítica literária mediada pela teoria andrógina. Nada

\footnotetext{
52 “o mundo dos homens". Ibid., p.133.

53 “em si a centelha da mulher". Ibid., p. 134.

54 “faltava -lhes o poder de sugestão". Ibid., p. 134.
} 
nessa teoria, portanto, teria a ver com a forma do ensaio como unidade criadora conciliadora dos contrários, mas sim, com as suas fraquezas e recalques como mulher.

Lucia Miguel Pereira acredita que Virginia Woolf também tenha se utilizado dos pressupostos feministas acerca das reivindicações das mulheres por um mundo onde pudessem melhor se integrar e exercer seus direitos humanos, políticos e civis, a fim de sustentar a teoria crítica da androginia. Por não poder fazer uso apenas do mito, o que seria uma atitude minimalista, a escritora inglesa teria preferido conceber uma das vertentes do andrógino como uma condição social de igualdade entre homens e mulheres, uma espécie de aparato sociológico, vinculando, assim, sua teoria crítica ao feminismo. É daí que surge seu discurso com ares feministas, isto é, sua elaboração estética sobre a nova forma do ensaio carecia urgentemente do apoio e da completude do discurso feminista, sociologicamente embasado, para demonstrar a necessidade da união entre os opostos, não apenas na criação literária como também em todas as áreas de atuação, principalmente a social.

De acordo com Lucia Miguel Pereira, Woolf tentou mascarar sua "fragilidade sofisticadamente feminina" ${ }^{, 55}$ ao utilizar-se dos contornos do feminismo para sustentar sua teoria crítica, que possivelmente pereceria se explicada somente pelo viés do mito. O resultado de tal tentativa, na verdade, foi mal-sucedido e, ao invés de aliar e ampliar os domínios da crítica literária ao feminismo, Virginia Woolf passou a assumir o clássico e estereotipado papel da feminilidade excessiva perante o poder exercido e imposto pelo mundo masculino. Mais do que um posicionamento ideológico acerca da posição social da mulher quando comparada ao homem, o que Virginia Woolf sentia era "uma constrangedora consciência de sexo",56, diz Pereira, que a induziu a uma

\footnotetext{
${ }^{55}$ PEREIRA, Lucia Miguel. Escritos da maturidade. Rio de Janeiro: Grafia, 2005. p. 114.

${ }^{56}$ Ibid., p. 114.
} 
conflituosa e ambígua relação com o homem, um misto de amor e ódio, de admiração e ressentimento.

Herbert Marder, em Feminismo e arte - um estudo sobre Virginia Woolf, publicado originalmente em 1968, também aponta para esse rancor da crítica inglesa com relação ao sexo oposto, marcado, principalmente, pela imagem tirânica de seu pai:

Ela [Woolf] não conseguia parar de ruminar suas mágoas, embora avisasse repetidamente aos outros para não fazê-lo. (...) qualquer traço de condescendência masculina fazia com que ela sofresse agonias. Ela era vulnerável porque (...) sentia profunda reverência pelo intelecto masculino, uma reverência que não obstava o ressentimento, mesmo o ódio. A filha de Leslie Stephen está ainda lutando contra o fantasma de seu pai, aquele velho terrível. ${ }^{57}$

Maggie Humm, na obra Feminist criticism, de 1986, a respeito da mesma questão, escreve:

Although the themes and ideas she [Woolf] discussed - of female friendship and the representation of women- are those that feminists regard as central to feminist theory, it is not only the questions that she wrestled with and answers that she gave us which make Virginia Woolf feminist. (...). It is in the very structure of her discourse that she engages in a feminist battle with her father and with her male friends.

O questionamento de Woolf como feminista é motivo de uma grande controvérsia entre os críticos literários e outros autores que também se debruçaram sobre a questão. Pereira, portanto, bem antes das críticas sobre o assunto, já havia percebido uma confusão em Woolf a respeito dos conceitos de feminilidade e feminismo, e os separou,

\footnotetext{
${ }^{57}$ MARDER, Herbert. Tradução Fernando Cabral. Feminismo e arte - um estudo sobre Virginia Woolf. Belo Horizonte: Interlivros, 1975. P. 105.

58 "Embora os temas e ideias que ela [Woolf] discutia - da amizade feminina e da representação das mulheres - sejam aqueles que as feministas consideram como importantes para a teoria feminista, não são somente essas questões que ela discutiu e as respostas que nos deu que fazem de Virginia Woolf uma feminista. (...). É na própria estrutura de seu discurso que ela se envolve em uma luta feminista com seu pai e seus amigos do sexo masculino." HUMM, Maggie. Feminist criticism. London: Harvest Wheatsheaf, 1986. p. 124. Tradução nossa.
} 
uma vez que, segundo ela, o primeiro é um conceito psicológico “indispensável às autoras" $" 59$ e o outro é de natureza social, "inteiramente alheio às atividades do espírito." ${ }^{60} \mathrm{O}$ excesso de feminilidade em Woolf, segundo a crítica brasileira, a fragilizou de tal maneira que a conduziu a uma intrincada confusão com o feminismo, o qual desembocou na tentativa mal-sucedida de sustentar a androginia como forma para a criação literária. O espaço de convivência dos opostos como unidade criadora do ensaio, alicerçado pela teoria de igualdade de direitos advinda do feminismo, enfim, tornou-se um local bem diferente daquele onde deveria ser encontrada a crítica literária e passou a ser uma região dos conflitos pessoais que marcaram a escritora inglesa.

Há realmente um impasse sobre Woolf como feminista. O que pode ser ponderado é que ela apoiou a causa sufragista e realizou palestras de cunho ideológico voltadas para mulheres. $\mathrm{O}$ fato de parecer não ter tido um engajamento político prático, ativista, mas apenas teórico, é que dificulta inseri-la totalmente nesse movimento. Em oposição a Lucia Miguel Pereira, alguns autores a consideram feminista apenas em relação aos princípios que fundamentam sua estética literária. Maggie Humm, na obra Feminist criticism, por exemplo, afirma que "Virginia Woolf was the first woman writer to write a female aesthetic. Her recognition that literature (...) is determined by the gender of the author is what makes her eligible to be called a feminist."

Alex Zwerdling comenta, em Virginia Woolf and the real world, que a participação de Woolf como ativista do movimento sufragista, de natureza feminista, foi um tanto tímida e passageira: "Woolf's career as an activist was short- lived. Though she attended meetings and addressed envelopes for the cause, her letters in 1910 reveal

\footnotetext{
${ }^{59}$ PEREIRA, Lucia Miguel. Escritos da maturidade. Rio de Janeiro: Grafia, 2005. p. 115.

${ }^{60}$ Ibid., p. 115.

61 "Virginia Woolf foi a primeira mulher a escrever uma estética feminina. Seu reconhecimento de que a literatura (...) é determinada pelo gênero do autor é o que a qualifica para ser chamada de feminista.’HUMM, Maggie. Feminist criticism. London: Harvester Wheatsheaf. p. 123. Tradução nossa.
} 
that she did so with increasing reluctance and detachment. The work seemed mechanical, the speeches perfectly predictable."

Nesse sentido, uma carta para sua tutora Janet Case, em 1910, sobre a campanha pelo voto feminino na Inglaterra, citada no livro The Cambridge companion to Virginia Woolf, nos deixa entrever tal timidez em sua atuação:

Would it be any use if I spent an afternoon or two weekly in addressing envelopes for the Adult Suffragists? I don't know anything about the question. (...) I could neither do sums or argue, or speak, but I could do the humbler work if that is any good. (...) The only way to better it is to do something I suppose. How melancholy it is that conversation isn't enough! ${ }^{63}$

Por outro lado, em seu diário de 23 de outubro de 1929, antes de publicar A room of one's own, Virginia Woolf demonstra certa preocupação com uma possível confusão entre a presença do feminino e a ideologia feminista em sua obra: "It is a little ominous that Morgan wont (sic) review it [o livro]. It makes me suspect that there is a shrill feminine tone in it which my intimate friends will dislike. (...) I shall be attacked for a feminist \& hinted at for a sapphist (...),64.

Em uma carta escrita em 1916, Woolf surpreende ao declarar-se feminista: "I become steadily more feminist owing to the Times, which I read at breakfast and

\footnotetext{
62 "A carreira de Woolf como ativista foi de curta duração. Embora ela comparecesse a reuniões e subscritasse envelopes para a causa, suas cartas de 1910 revelam que ela o fez com muita hesitação e distanciamento. O trabalho parecia mecânico, os discursos totalmente previsíveis." ZWERDLING, Alex. Virginia Woolf and the real world. Los Angeles: University of California Press, 1986. p. 213. Tradução nossa.

63 "Seria de alguma utilidade se eu passasse uma tarde ou duas por semana subscritando envelopes para as sufragistas? Eu não sei nada sobre a questão. (...) Eu não posso nem angariar fundos, nem discutir, ou falar, mas eu poderia fazer o trabalho mais simples se for de alguma valia. (...) Suponho que o melhor modo de melhorar é fazer alguma coisa. É pena que as conversas não bastem!” ROE, Sue e SELLERS, Susan (Ed.). The Cambridge companion to Virginia Woolf. Cambridge: CUP, 2000. p. 211. Tradução nossa.

64 "Fico um pouco apreensiva que Morgan não fará a crítica dele [do livro]. Isso me faz imaginar que há nele um tom feminino muito forte, do qual meus amigos íntimos não gostarão. (...) Serei atacada como feminista \& chamada de lésbica." WOOLF, Virginia. The diary of Virginia Woolf. Vol.3. 1925-1930. New York: Harvest, 1980. p. 262. Tradução nossa.
} 
wonder how this preposterous masculine fiction [the First World War] keeps going a day longer - without some vigorous Young woman pulling us together and marching through it." 65

A atitude confusa entre crítica literária (androginia), excesso de feminilidade (fonte dos problemas pessoais) e feminismo (discurso social), que, segundo Pereira, caracteriza a forma do ensaio pensada e arquitetada por Woolf em $A$ room of one's own também foi evidenciada por uma crítica norte-americana, Elaine Showalter, cujo livro $A$ literature of their own afirma que: "Androgyny was the myth that helped her [Woolf] evade confrontation with her own painful femaleness and enabled her to choke and repress her anger and ambition." ${ }^{\text {"66 }}$ Showalter questiona aí o feminismo de Woolf, uma vez que a defesa da androginia como forma literária para Virginia Woolf seria apenas uma solução para o dilema que envolvia questões pessoais e problemas relacionados à família e à sociedade.

Com efeito, em A room of one's own, Woolf pontua as desigualdades entre o homem e a mulher de forma veemente. Denuncia o sentimento de superioridade do masculino, seu amor pelo poder, pelas posses e a necessidade de manter a mulher em uma posição inferior para que o homem possa continuar no comando. $\mathrm{O}$ feminino, por sua vez, é enaltecido como o sustentáculo do masculino, a versão sensível e apaziguadora sem a qual o mundo penaria na escuridão e na selvageria:

Women have served all these centuries as looking glasses possessing the magic and delicious power of reflecting the figure of man at twice

\footnotetext{
65 “Torno-me cada vez mais feminista por causa do Times, que leio no café da manhã, e penso como essa absurda ficção masculina [a Primeira Guerra Mundial] continua cada vez mais sem uma mulher Jovem e forte nos impulsionando e caminhando para a luta." ROE, Sue e SELLERS, Susan. The Cambridge companion to Virginia Woolf. Cambridge: CUP, 2000. p. 224. Tradução nossa.

66 "A androginia foi o mito que a [Woolf] ajudou a evitar o confronto com sua dolorosa feminilidade e lhe possibilitou sufocar e reprimir seu ódio e ambição." SHOWALTER, Elaine. A literature of their own. New Jersey: Princeton University Press, 1999. p. 264. Tradução nossa.
} 
its natural size. Without that power probably the earth would still be swamp and jungle. The glories of all our wars would be unknown.(...) That is why Napoleon and Mussolini both insist so emphatically upon the inferiority of women, for if they were not inferior, they would cease to enlarge. ${ }^{67}$

Com isso, Woolf estende seu ponto de vista sobre a posição da mulher por toda a sociedade patriarcal como se quisesse conscientizá-la acerca da necessidade de descobrir seu real valor e deixar de assumir uma atitude passiva frente à falsa superioridade masculina imposta pelo autoritarismo. Mussolini e Napoleão, nessa passagem, são os ícones que reúnem e representam as características da opressão masculina. Ao comentar uma carta do Daily Telegraph, ela afirma que "there we have in embryo the creature, Dictator as we call him when he is Italian or German, who believes that he has the right whether given by God, Nature, sex or race is immaterial, to dictate to other human beings how they shall live; what they shall do." 68

Pereira, ao abordar essa questão, sente que a relação de Virginia Woolf com o autoritarismo masculino foi realmente personificada no ditador italiano e ainda afirma que "no fascismo, não foi a opressão que unicamente a horrorizou; achou intolerável em Roma o ambiente criado por Mussolini, de predomínio exclusivo dos homens, de confinação das mulheres às atividades estritamente domésticas."

Às mulheres da época de Woolf eram delegadas atividades centradas nos afazeres domésticos e negada a autonomia de ação, expressão e existência por conta própria.

\footnotetext{
67 "Em todos esses séculos, as mulheres têm servido de espelhos dotados do mágico e delicioso poder de refletir a figura do homem com o dobro de seu tamanho natural. Sem esse poder, a Terra provavelmente ainda seria pântano e selva. As glórias de todas as nossas guerras seriam desconhecidas. (...) Eis por que tanto Napoleão quanto Mussolini insistem tão enfaticamente na inferioridade das mulheres, pois não fossem elas inferiores, eles deixariam de engrandecer-se." WOOLF, Virginia. Um teto todo seu. Tradução de Vera Ribeiro. Rio de Janeiro: Nova Fronteira, 1985. p. 48.

68 "ali há em forma embrionária a criatura, Ditador, como nós o chamamos quando ele é italiano ou alemão, que acredita que tem o direito, se dado por Deus, natureza, sexo ou raça é imaterial, para impor aos outros seres humanos como eles devem viver; o que eles devem fazer." ROE, Sue e SELLERS, Susan (Ed.) The Cambridge companion to Virginia Woolf. Cambridge: CUP, 2000. p. 224. Tradução nossa.

${ }^{69}$ PEREIRA, Lucia Miguel. Escritos da maturidade. Rio de Janeiro: Grafia, 2005. p.113-114.
} 
Podiam cursar uma faculdade, por exemplo, mas não lhes era permitida a obtenção da titulação universitária, além do fato de ser vedada a possibilidade de trabalho em uma sociedade patriarcal, que chegou até mesmo a desenvolver pesquisas científicas com o intuito de provar a baixa capacidade intelectual da mulher perante o homem. Sobre esse último fato, Woolf afirma: "Mr. Oscar Browning was wont to declare 'that the impression left on his mind, after looking over any set of examination papers, was that, irrespective of the marks he might have, the best woman was intellectually the inferior of the worst man." 70

Ela se opôs energicamente a uma visão da mulher confinada à vida doméstica, muito difundida na Era Vitoriana (1837-1901) e ainda mesmo no século XX. A mulher/esposa ideal, devotada, piedosa, pura e submissa ao marido era denominada "the angel in the house" ${ }^{, 71}$. Essa denominação passou a qualificar um perfil feminino talhado para a vida doméstica, isto é, sem vida político-social, desejos próprios e existência autossuficiente. A resposta da crítica inglesa a essa imagem pode ser encontrada no ensaio "Professions for women", de 1931:

You who come of a younger and happier generation may not have heard of her- you may not know what I mean by the Angel in the House. (...) she was so constituted that she never had a mind or a wish of her own, but preferred to sympathize always with the minds and wishes of others. (...) her purity was supposed to be her chief beauty (...) I turned upon her and caught her by the throat. I did my best to kill her. My excuse, if I were to be had up in a court of law, would be that I acted in self defence. Had I not killed her she would have killed me. ${ }^{72}$

\footnotetext{
70 “O Sr. Oscar Browning tinha o hábito de declarar 'que a impressão deixada em sua mente, após examinar qualquer conjunto de provas, era que, independentemente das notas por ele conferidas, a melhor dentre as mulheres era intelectualmente inferior ao pior dentre os homens'." WOOLF, Virginia. Um teto todo seu. Trad. de Vera Ribeiro. Rio de Janeiro: Nova Fronteira, 1985. p. 70.

${ }^{71}$ Conforme nos referimos no capítulo 1 .

72 "Vocês que são de uma geração mais jovem e mais feliz podem não ter ouvido falar dela - vocês podem não saber o que quero dizer por Anjo da Casa. (...) ela era constituída de tal modo que nunca tinha uma opinião ou desejo, mas preferia sempre compreender as opiniões e desejos dos outros. (...) supunhase que sua pureza era seu melhor valor (...). Ataquei-a e a peguei pela garganta. Fiz o máximo para matála. Minha desculpa, caso fosse parar no tribunal, seria que eu agi em legítima defesa. Se eu não a tivesse
} 
Enfim, o que motiva essa discussão, na realidade, não é apresentar uma conclusão sobre o fato de Virginia Woolf pertencer ou não ao movimento feminista, mas elencar uma série de pareceres, os de Lucia Miguel Pereira, de outros autores e da própria Virginia Woolf, acerca das relações do feminismo com a crítica literária ou, mais especificamente, com a teoria crítica da androginia, que sustenta a nova forma do ensaio proposta pela autora inglesa. A integração entre a "coisa literária"73 e a "coisa pública"74, que Pereira discute em um ensaio intitulado "O ofício de compreender", não se completa na teoria enunciada em A room of one's own, uma vez que o discurso social que pretende ser uma reflexão advinda da crítica é apenas um desabafo pessoal das dificuldades existenciais de Woolf.

matado, ela teria me matado." BARRET, Michèle. (Ed.) Women and writing. New York: Harvest, 1980. P. 58-59. Tradução nossa.

${ }^{73}$ PEREIRA, Lucia Miguel. A leitora e seus personagens. Rio de Janeiro: Grafia, 2005. p. 89.

${ }^{74}$ Ibid., p. 89. 


\section{CONCLUSÃO}

Lucia Miguel Pereira lê com agudeza as inovações formais introduzidas por Virginia Woolf em seus ensaios, nos quais análise e ficcionalidade se associam de modo original. Nessa fusão das linguagens, o texto crítico é elevado à categoria de obra de arte, uma vez que desperta no leitor o prazer estético que apenas a arte é capaz de realizar, sem perder o vínculo com a análise e a reflexão.

Outro aspecto marcante, abordado neste trabalho, é como Pereira considera a recriação da temporalidade ficcional. Ela acredita ser necessária a presença de um tempo cronológico mais marcante para que a realidade externa seja reproduzida, o que proporciona a elaboração de um texto mais verossímil por meio de um enredo cujas ações se encadeiem numa sucessão de fatos. Embora reconheça a importância da abordagem psicológica na ficção, o seu uso excessivo implicaria uma construção temporal circular, a qual comprometeria as sequências das ações que compõem a trama, ou seja, as ações seriam sempre presentificadas e controladas pelo psiquismo das personagens.

A partir do olhar de Pereira com relação ao ensaio e romance virginianos, demonstrou-se a estética que orienta a crítica brasileira. Woolf, dessa forma, serviu como base para as conclusões a respeito dos pensamentos de Lucia Miguel Pereira no tocante à forma do ensaio e à temporalidade na ficção.

No âmbito da crítica literária, Pereira destacou-se igualmente pela natureza de seus ensaios, nos quais se debruçou sobre as mais diversas obras. Publicados em vários periódicos, foram vazados em um estilo objetivo, claro e instigante, convidando o leitor a participar de suas reflexões analíticas. Nesse sentido, aproxima-se da forma ensaística de Woolf. Seu exercício crítico orienta-se pela busca da compreensão e ressalta a importância do papel da avaliação precisa a fim de evitar um julgamento prévio da obra a ser analisada. 
Desse modo, comenta no ensaio "Crítica e controvérsia": "A crítica dirige-se diretamente à inteligência, envolvendo sempre o plano das idéias, ainda quando avalia obras puramente emocionais, porque explica, logo racionaliza."75

Pereira também reiterou, tanto na ensaística quanto na ficção, o interesse pelo humano, ou seja, tanto a análise crítica como o texto romanesco visavam abordar, em última instância, questões que pudessem ser aplicadas ao gênero humano em seu caráter universal. Apreciou sobremaneira a ficção machadiana cuja obra, segundo a autora, foi "uma constante e cerrada busca da verdade. Não da verdade absoluta, que esse relativista conhecia impossível ou pelo menos inatingível, mas da verdade humana, precária e mutável.,"76

As diferenças entre Pereira e Woolf, no entanto, podem ser explicadas pelo contexto em que estavam inseridas, cujo resultado indica visões de mundo discrepantes. No caso da escritora brasileira, uma realidade social opressora demandava uma literatura mais voltada para as questões do dia-a-dia. Já no caso de Woolf, as inovações no campo científico e tecnológico propiciaram um maior questionamento existencial. O caráter mais subjetivo dos textos virginianos, característico do romance de sua época, permitiu-lhe afirmar que nos escritores modernos o interesse "lies very likely in the dark places of psychology."77 Daí a incompatibilidade de suas elaborações ficcionais no que concerne à temporalidade.

A fim de exemplificar essa divergência, analisamos Mrs. Dalloway, To the lighthouse e Amanhecer, e pontuamos as oposições estabelecidas pelas autoras, de modo a deduzir que o romance da escritora brasileira está mais próximo de To the lighthouse, pelo modo de apresentação do tempo nos romances.

\footnotetext{
${ }^{75}$ PEREIRA, Lucia Miguel. A leitora e seus personagens. Rio de Janeiro: Grafia, 2005. p. 92.

${ }^{76}$ PEREIRA, Lucia Miguel. Prosa de ficção: de 1870 a 1920. Belo Horizonte: Itatiaia/São Paulo: EDUSP, 1988. p.103.

77 “encontra-se muito provavelmente nos lugares escuros da psicologia. WOOLF, Virginia. Virginia Woolf-Selected essays. David Bradshaw (Ed.). New York: Oxford University Press, 2008. p. 11. Tradução nossa.
} 
Concluiu-se que Lucia Miguel Pereira e Virginia Woolf têm características estéticas comuns quando falamos sobre a forma do ensaio, apesar de divergirem acerca da construção do tempo na ficção. Essa diferença emerge na maneira de conceberem seus romances, que, como tratado ao longo deste trabalho, é perfeitamente explicável quando se considera suas realidades distintas. No entanto, a sensibilidade das autoras ao tratarem das questões que afligem a alma humana, principalmente a feminina, as coloca em um plano semelhante e lhes concede uma dignidade que, ao mesmo tempo em que as distingue, também as aproxima no mundo literário. 


\section{REFERÊNCIAS}

\section{OBRAS DE LUCIA MIGUEL PEREIRA}

PEREIRA, Lucia Miguel. Amanhecer. Rio de Janeiro: Livraria José Olympio, 1938.

As mulheres na literatura brasileira. Anhembi, São Paulo, p. 24, dez. 1954.

Machado de Assis- Estudo crítico e biográfico. Belo Horizonte: Itatiaia; São Paulo: EDUSP, 1988.

Prosa de ficção. Belo Horizonte: Itatiaia; São Paulo: EDUSP, 1988.

A leitora e seus personagens. Pesquisa bibliográfica, seleção e notas: Luciana

Viégas. Rio de Janeiro: Grafia, 2005.

Escritos da Maturidade. Introdução, seleção e notas: Luciana Viégas. Rio de Janeiro: Grafia, 2005.

Ficção reunida. Curitiba: Ed. da UFPR, 2006. 


\section{OBRAS SOBRE LUCIA MIGUEL PEREIRA}

ALMEIDA, Edwirgens Aparecida Ribeiro Lopes de. Reiventando a realidadeestratégias de composição da ficção de Lúcia Miguel Pereira. Tese de DoutoradoUniversidade de Brasília, Brasília, 2010.

BILENKY, Marlene. O claro olhar (análise da personagem feminina na ficção de Lúcia Miguel Pereira). Dissertação de Mestrado-Universidade de São Paulo, São Paulo,1986.

CANDIDO, Antonio. Lucia. In: O albatroz e o chinês. Rio de Janeiro: Ouro sobre Azul, 2004. P. 127-132.

CAVENDISH, Márcia Wanderley. A primeira crítica literária brasileira. O Estado de São Paulo, São Paulo, p. 4, 29 dez. 2001.

Lucia Miguel Pereira- Crítica literária e pensamento católico no Brasil. Tese (Doutorado em Letras)-Pontifícia Universidade Católica, Rio de Janeiro, 1987.

GOTLIB, Nádia. A literatura feita por mulheres no Brasil. In: Working Paper Series. University of Oxford Centre for Brazilian Studies, 1998.

LAJOLO, Marisa. Regionalismo e história da literatura: Quem é o vilão da história? In: Historiografia brasileira em perspectiva. São Paulo: Ed. Contexto/Instituto Franciscano de antropologia, 2001. P. 297-328.

MARDEN, Elizabeth. Critical Acts - Latin American women criticism. Florida: Florida University Press, 1999.

ROCHA, Izaura Regina. Crítica, romance e gênero - Uma perspectiva convergente da obra de Lucia Miguel Pereira. Dissertação de Mestrado-Universidade Federal de Juiz de Fora, Juiz de Fora, 2010.

VIÉGAS, Luciana. Lições de pesquisa literária - O legado crítico de Lucia Miguel Pereira. Dissertação (Mestrado em Ciência da Literatura)-Universidade Federal do Rio de Janeiro, Rio de Janeiro, 2005. 


\section{OBRAS DE VIRGINIA WOOLF}

WOOLF, Virginia. The moment and other essays. London: The Hogarth Press, 1947.

. The captain's death bed and other essays. London: Hogart Press, 1950.

Granite and rainbow. New York: Harvest/Harcourt, 1958.

. Orlando. Tradução Cecília Meireles. Rio de Janeiro: Nova Fronteira, 1958.

. Orlando, a biography. New York: Penguin Books, 1963.

. Contemporary writers. New York: Harcourt Brace Jovanovich, 1976.

Moments of being. Jeanne Schulkind (Ed.). London: Triad Grafton Books, 1976.

. The diary of Virginia Woolf. Vol. 1. 1915-1919. Anne Olivier Bell (Ed.). New York: Harcourt Brace Jovanovich, 1978.

. The diary of Virginia Woolf. Vol. 2. 1920-1924. Anne Olivier Bell (Ed.). New York: Harcourt Brace Jovanovich, 1978.

. The diary of Virginia Woolf. Vol. 3. 1925-1930. Anne Olivier Bell (Ed.). Orlando: Harvest, 1980.

. Mrs. Dalloway. Tradução Mário Quintana. Rio de Janeiro: Nova Fronteira, 1980.

. The death of the moth and other Essays. Anne Olivier Bell (Ed.). London: The Hogarth Press, 1981.

. The diary of Virginia Woolf. Vol. 4. 1931-1935. Anne Olivier Bell (Ed.). New York: Harcourt Brace Jovanovich, 1982.

A Haunted House and Other Stories. London: Grafton Books, 1982. 
The diary of Virginia Woolf. Vol. 5. 1936-1941. Anne Olivier Bell (Ed.). New York: Harcourt Brace Jovanovich, 1984.

. The common reader: First series. New York: HarcourtBooks, 1984.

. Um teto todo seu. Tradução Vera Ribeiro. Rio de Janeiro: Nova Fronteira, 1985.

. The common reader: Second series. New York: HarcourtBooks, 1986.

Passeio ao farol. Tradução Luiza Lobo. Rio de Janeiro: Rio Gráfica, 1987.

. The essays of Virginia Woolf. Vol 2. Andrew Mcneille (Ed.). New York: Harcourt Brace Jovanovich, 1987.

. The essays of Virginia Woolf. Vol 1. Andrew Mcneille (Ed.). New York: Harcourt Brace Jovanovich, 1989.

Congenial spirits. Joanne Trautmann (Ed.). Orlando: Harvest, 1990.

A room of one's own. Oxford: Oxford University Press, 1992.

. As ondas. Tradução Lucília Rodrigues. Lisboa: Publicações Europa-América, 1992.

. Jacob's room. London: Penguin Books, 1992.

. The voyage out. London: Penguin Books, 1992.

. To the lighthouse. London: Penguin Books, 1992.

. Three guineas. Oxford: Oxford University Press, 1992.

. Mrs Dalloway, London: Wordsworth Classics, 1996.

The waves. London: Penguin Books, 2000. 
O leitor comum. Tradução Luciana Viégas. Rio de Janeiro: Graphia, 2007.

Virginia Woolf-Selected essays . David Bradshaw (Ed.). New York: Oxford University Press, 2008.

Revista Alicantina de estúdios ingleses. p. 214. Disponível em:

<http://rua.ua.es>. Acesso em: 03 set. 2011. 


\section{OBRAS SOBRE VIRGINIA WOOLF}

BALDWIN, Dean R. Virginia Woolf - A study of the short fiction. Boston: Twayne Publishers, 1989.

BARRET, Michèle. Virginia Woolf - women and writing. New York: Harvest, 1980.

BATCHELOR, John. Virginia Woolf - The major novels. Cambridge: Cambridge University Press, 1991.

BEER, Gillian. Virginia Woolf: The common ground. Edinburgh: Edinburgh University Press, 1996.

BLACKSTONE, Bernard. Virginia Woolf - A commentary. London: The Hogarth Press, 1949.

BOWLBY, Rachel. Feminist destinations and further essays on Virginia Woolf. Edinburgh: Edinburgh University Press, 1997.

BOWLBY, Rachel. Killing the angel in the house. London: Penguin Books, 1995.

BRIGGS, Julia. Virginia Woolf- An inner life. New York: Harcourt Books, 2005.

Reading Virginia Woolf.Edinburgh: Edinburgh University Press Ltd, 2006.

CAMARGO, Mônica Hermini de. Virginia Woolf e seus ensaios.Tese de DoutoradoUniversidade de São Paulo, São Paulo, 2006.

CHAMBERS, R. L. The novels of Virginia Woolf. London: Oliver \& Boyd Ltd., 1957.

DAICHES, David. The novel and the modern world - Conrad/ Galsworthy/Huxley/Joyce/Masnfield/Woolf. Chicago: The University of Chicago Press, 1947.

Virginia Woolf. Chicago: The University Chicago Press, 1960. 
DUBINO, Jeanne and ROSENBERG, Beth Carole (Ed.). Virginia Woolf and the essay. New York: St. Martin's Press, 1998.

GOLDMAN, Mark. The reader's art: Virginia Woolf as literary critic. Paris: Mouton,1976.

GORDON, Lyndall. Virginia Woolf: A writer's life. Oxford: Oxford University Press, 1986.

HANSON, Claire. Women writers: Virginia Woolf. London: Macmillan, 1994.

HARPER, Howard. Between Language and silence - the novels of Virginia Wolf. Baton Rouge: Lousiana State University Press, 1982.

LATHAM, Jaqueline (Ed.). Critics on Virginia Woolf, London: George Allen and Unwin, 1970.

LEE, Hermione. The novels of Virginia Woolf. London: Methuen, 1977. Virginia Woolf. London: Vintage, 1997.

MADJUMAR, Robin e McLAURIN, Allen (Ed.) Virginia Woolf - The critical heritage. London: Routledge \& Kegan Paul, 1975.

MARDER, Herbert. Tradução Fernando Cabral. Feminismo e arte - um estudo sobre Virginia Woolf. Belo Horizonte: Interlivros, 1975.

MARSH, Nicholas. Virginia Woolf-The novels.New York:ST. Martin's Press,1998.

McLAURIN, Allen. Virginia Woolf. Cambridge: Cambridge University Press, 1973.

MOODY, A.D. Virginia Woolf. Edinburgh: Oliver and Boyd, 1963.

MULHERN, Francis. Virginia Woolf and Cultural Criticism (Working Papers in British Studies 2). São Paulo, Departamento de Letras Modernas/FFLCH/USP, 1998. 
NELSON, Kelly Egan. The concept of time in the novels of Virginia Woolf . Dissertação (Mestrado). Lubbock, Texas Tech University, 1969.

OLIVEIRA, Solange Ribeiro de. Virginia Woolf's Silver Globe. Belo Horizonte: Imprensa da Universidade de Minas Gerais, 1962.

REID, SU. (Ed.) Mrs Dalloway and To the lighthouse. Basingstoke/London: Macmillan Press, 1993.

ROE, Sue. Writing and Gender: Virginia Woolf's Writing Practice. Hemel Hempstead: Harvester Wheatsheaf/ New York: St. Martin's Press, 1990.

and SELLERS, Susan (Ed.). The Cambridge companion to Virginia Woolf. Cambridge: Cambridge University Press, 2000.

RUOTOLO, Lucio P. The interrupted moment- A view of Virginia Woolf's novels. Stanford: Stanford University Press, 1986.

SASKIA, Lührig. Concepts of time in To the lighthouse and Mrs. Dalloway by Virginia Woolf (Seminar paper). Colônia: GRIN, 2006.

SCHULKIND, Jeanne (Ed.). Virginia Woolf: Moments of Being. London: Triad Grafton Books, 1986.

SHARMA, Vijay L. Virginia Woolf as literary critic- A revaluation. New Delhi: Arnold-Heinemann, 1977.

SPRAGUE, Clare. (Ed.) Virginia Woolf- a collection of critical essays. New Jersey: Prentice Hall, 1971.

SUGIYAMA, Yoko. Virginia Woolf and Feminism. Nishinomiya: Kwansei Gakuin University, 1966. A study of To the lighthouse. Nishinomiya: Kwansei Gakuin University, 1968. 
TRAUTMANN, Joanne. (Ed.). Congenial spirits. New York: Harvest, 1990.

VV. AA. Ilha do Desterro - Virginia Woolf. Revista do curso de Pós-graduação em Literatura Inglesa. Florianópolis: Ed. da UFSC, n. ${ }^{\circ}$ 24, 1990.

WHITWORTH, Michael. Virginia Woolf. Oxford: OUP, 2005.

WOOLF, Leonard (Ed.). A writer's diary. Glasgow, Triad Granada, 1983.

Contemporary writers. New York: Harcourt Brace Jovanovich,1976.

ZWERDLING, Alex. Virginia Woolf and the real world. Los Angeles: University of California Press, 1986. 


\section{REFERÊNCIAS GERAIS}

ADORNO, Theodor. Notas de literatura I - Trad. Jorge de Almeida. São Paulo: Duas Cidades/Ed. 34, 2003.

ALVES, Branca Moreira e PITANGUY, Jacqueline. O que é feminismo. São Paulo: Ed. Brasiliense, 1982.

ALVES, F.M. Filho. O sociologismo e a imaginação no romance brasileiro. Rio de Janeiro: Livraria José Olympio, 1938.

APPEL, Carlos Jorge et alii. O romance de 30. Porto Alegre: Movimento, 1983.

AUERBACH, Erich. Mimeses - A representação da realidade na literatura ocidental.. São Paulo: Perspectiva, 2002.

BALDWICK, Chris. The social mission of English criticism 1848-1932. Oxford: Clarendon/OUP, 1987.

BENJAMIN, Walter. Magia, técnica, arte e política: ensaios sobre literatura e história da cultura. Tradução de Sérgio Paulo Rouanet. São Paulo: Brasiliense, 1994.

BERGSON, Henri. Duração e simultaneidade. Tradução C. Berliner. São Paulo: Ed. Martins Fontes, 2006.

BOTTON, Alain. How Proust can change your life: Not a novel. New York: Random/ Pantheon, 1997.

BUENO, Luís. Uma história do romance de 30. São Paulo: EDUSP/Campinas: Ed. Da Universidade de Campinas, 2006.

CAMARGO, Flávio Pereira. Disponível em:

<http://www.ucm.es/info/especulo/numero 41/proustme.html.>. Acesso em: 07 nov. 2011.

CANDIDO, Antonio. A educação pela noite e outros ensaios. São Paulo: Ática, 2000. 
CANDIDO, Antonio et ali. A personagem de ficção. São Paulo: Perspectiva, 2000.

CANDIDO, Antonio. Formação da literatura brasileira. Belo Horizonte/Rio de Janeiro: Limitada, 1997.

Literatura e sociedade. São Paulo: Companhia Editora Nacional, 1980.

CASTELLO, José Aderaldo. A literatura brasileira. São Paulo: EDUSP, 1999.

CORTÁZAR, Julio. Valise de cronópio. São Paulo: Perspectiva, 1993.

COUTINHO, Afrânio. Da crítica e da nova crítica. Rio de Janeiro: Civilização Brasileira, 1957.

. Caminhos do pensamento crítico. Rio de Janeiro: Pallas, 1972.

COWLEY, Abraham. Lives of the poets. Disponível em:<www.gutenberg.org.> Acesso em: 25 ago. 2011.

DAICHES, David. The novel and the modern world. Chicago: The University of Chicago Press, 1947.

EAGLETON, Mary. (Ed.). Feminist literary criticism. New York: Longman, 1996.

EAGLETON, Terry. The function of criticism-From The Spectator to poststructuralism. London:Verso, 1990.

Teoria da literatura: uma introdução. Tradução Waltensir Dutra. São Paulo: Martins Fontes, 2001.

. The English novel - an introduction. Oxford: Blackwell, 2005.

FAUSTO, Boris. História Concisa do Brasil. São Paulo: EDUSP/Imprensa Oficial do Estado de São Paulo, 2001.

FILHO, Adonias. O romance brasileiro de 30. Rio de Janeiro: Edições Bloch,1969. 
FRYE, Northop. Anatomia da Crítica. Tradução Péricles E. da Silva Ramos. São Paulo: Cultrix, 1973.

GALVÃO, Sylvia C. Abbot. Revista Vivência, nº 31,UFRN, 2006.

GARDNER, Sebastião. "O inconsciente freudiano”. Disponível em: <http://www.cfh.ufsc.br>. Acesso em: 12 out. 2011.

GIL, Fernando C. "Contribuições da crítica latino-americana para o estudo do romance rural brasileiro". Disponível em: $<$ http:// www.ufjf.br/revistaipotesi $>$. p. 185. Acesso em: 30 mai. 2011.

GILBERT, Sandra e GUBAR, Susan. No man's land-the war of the words. Vol 1. New Haven: Yale University Press, 1988.

No man's land - sexchanges. Vol. 2. New Haven: Yale University Press, 1989.

No man's land-letters from the front. Vol 3. New Haven: Yale University Press, 1994.

GOOD, Graham. The observing self- Rediscovering the essay. New York: Routledge, 1988.

GOTLIB, Nádia. Teoria do conto. São Paulo: Ática, 1998.

HAMBURGER, Käte. A lógica da criação literária. São Paulo: Perspectiva, 1986.

HAHNER, June E. A mulher brasileira e suas lutas sociais e políticas 1850-1937. São Paulo: Brasiliense, 1981.

HEWITT, Douglas. English fiction of the early modern period, 1890 - 1940. New York: Longman, 1998.

HOLLANDA, Heloísa Buarque de \& ARAÚJO, Lucia Nascimento. Ensaístas brasileiras - Mulheres que escreveram sobre literatura e artes de 1860 a 1991. Rio de Janeiro: Rocco, 1993. 
HOLANDA, Sérgio Buarque de. "História da literatura brasileira-1870 1920”. In:

Banco de dados da Folha de São Paulo. Disponível em:

<http://almanaquefolhauol.com.br/sergiobuarque.htm>. Acesso em: 10 mai. 2011.

HUMM, Maggie. Feminist criticism- women as contemporary writers. London: Harvester Wheatsheaf, 1986.

HUMPHREY, Robert. O fluxo da consciência. Tradução de Gert Meyer. São Paulo: McGraw- Hill, 1976.

JAUSS, Hans Robert. A literatura e o leitor- textos de estética da recepção. Trad. Luiz da Costa Lima. Paz e Terra: Rio de Janeiro, 1979.

Toward an aesthestic of reception. Minnesota: University of Minnesota Press, 2005.

JONSON, Ben. Volpone. <www.gradesaver.com>. Acesso em: 23 ago. 2011.

KUMAR, Shiv K. Bergson and the stream of consciousness novel. New York: New York University Press, 1963.

LAFETÁ, João Luís. 1930: A crítica e o modernismo. São Paulo: Duas Cidades; Ed.34, 2000 .

LAJOLO, Marisa. Como e por que ler o romance brasileiro. Rio de Janeiro: Ed. Objetiva, 2004.

LEAVIS, Q.D. Fiction and the reading public. London: Chatto \&Windus, 1968.

LEVENSON, Michael (Ed.). The Cambridge Companion to modernism. Cambridge: CUP, 2009.

LOBO, Luiza. Crítica sem juízo. Rio de Janeiro: Garamond, 2007.

MARTINS, Maria Helena (org.). Rumos da crítica. São Paulo: SENAC, 2000. 
MENDILOW, A.A. O tempo e o romance. Tradução Flávio Wolf. Porto Alegre: Globo, 1972.

MEYERHOFF, Hans. O tempo na literatura. Tradução Myriam Campello. São Paulo: Ed. McGraw - Hill do Brasil, 1976.

MICELI, Sérgio. Intelectuais e classe dirigente no Brasil. São Paulo: DIFEL, 1979.

MOI, Toril. Sexual/textual politics: feminist literary theory. London: Methuen, 1985.

NAZARIO, Diva Nolf . Voto feminino \& feminismo.São Paulo: Imprensa Oficial, 2009.

NINA, Cláudia. Literatura nos jornais - A crítica literária dos rodapés às resenhas. São Paulo: Summus, 2007.

NUNES, Benedito. O tempo na narrativa. São Paulo: Ática, 2000.

OLIVEIRA, Lucia Lippi, VELlOSO, Mônica Pimenta, GOMES, Ângela M. Castro. Estado Novo- Ideologia e poder. Rio de Janeiro: Zahar, 1982.

PARSONS, Deborah. Theorists of the modernist novel. New York: Routledge, 2007.

PINTO, Celi Regina Jardim. Uma história do feminismo no Brasil. São Paulo: Fundação Perseu Abramo, 2003.

PINTO, Cristina Ferreira. O bildungsroman feminino: quatro exemplos brasileiros. São Paulo: Perspectiva, 1990.

PONTES, Heloísa. Intérpretes da metrólope. São Paulo: EDUSP, 2010.

PROUST, Marcel. No caminho de Swann. Tradução Fernando Py. Rio de Janeiro: O Globo; São Paulo: Folha de São Paulo, 2003.

RIBEIRO, Lavínia. Imprensa e espaço público. Rio de Janeiro: E-paper, 2004. 
RAMALHO, Cristina. (Org.). Literatura e feminismo - propostas teóricas e reflexões críticas. Rio de Janeiro: Elo, 1999.

ROCHA, João Cezar de Castro. Exercícios críticos- Leituras do contemporâneo.

Chapecó: Argos, 2008.

ROSENFELD, Anatol. Texto/Contexto I. São Paulo: Perspectiva, 1996.

ROSSETTI, Regina. “Acordes e dissonâncias entre Bergson e Proust”. Disponível em: <http://www.revistafilosofia.unisinos.br>. Acesso em: 08 nov. 2011.

SAHN, Estela. Bergson e Proust- Sobre a representação da passagem do tempo.São Paulo: Iluminuras, 2011.

SAINSTSBURY, George. A history of English criticism. New Delhi: Atlantic, 2004.

SANTOS, Pedro Brum. Teorias do romance. SantaMaria: UFSM, 1996.

SHAKESPEARE, William. The Oxford Shakespeare- complete works. Oxford: OUP, 1988.

. "Shakespeare- complete works. Oxford: Clarendon Press,1994, p.752.

Tradução de Ivo Barroso. Disponível em: <http://www.lovers-poems.com>. Acesso em: 03 jun. 2011.

SHIACH, Morag (Ed.). The Cambridge companion to the modernist novel. Cambridge: CUP, 2007.

SHOWALTER, Elaine. A Literature of Their Own: British Women Novelists from Brontë to Lessing. Princeton: Princeton University Press, 1977.

SODRÉ, Nelson Werneck. A história da imprensa no Brasil. Rio de Janeiro: Civilização Brasileira, 1966. História da literatura brasileira. Rio de Janeiro: Civilização Brasileira, 1964. 
SPEARMAN, Diane. The novel and society.London: Routledge and Kegan Paul,1966.

STUBBS, Patricia. Women \& Fiction. London: Methuen \& Co. 1981.

SUSSEKIND, Flora. Tal Brasil, qual romance. Rio de Janeiro: Achiamé, 1984.

TELES, Maria Amélia de Almeida. Breve história do feminismo no Brasil. São Paulo: Brasiliense, 2003.

VASCONCELOS, Sandra. A formação do romance inglês. São Paulo: Hucitec/FAPESP, 2007.

VV. AA. A crítica literária. São Paulo: Martins Fontes, 1977.

VV. AA. Ensaístas ingleses. Vol. XXVII. Prefácio de Lúcia Miguel Pereira. Tradução de J. Sarmento de Beires e Jorge Costa Neves. São Paulo: Jackson Inc. Editores, 1950.

VV. AA. A Ordem. Rio de Janeiro: Centro Dom Vital, 1933. Vols.39-40, Maio/Junho/1933.

VV. AA. A Ordem. Rio de Janeiro: Centro Dom Vital, 1932. n 32, Outubro/1932.

WALKER, Hugh. The English essay and essayists. Kolkata: Books Way, 2011.

WATT, Ian. A ascensão do romance. Tradução Hildegard Feist. São Paulo: Companhia das Letras, 1996. 